


\section{Overzicht handelingsperspectieven voor beleid gericht op extensivering van de landbouw}

Zoe van Eldik ${ }^{1}$, Judith Westerink ${ }^{1}$, Raymond Schrijver ${ }^{1}$, Marijke Dijkshoorn-Dekker ${ }^{2}$, Jeroen Schütt ${ }^{1}$

1 Wageningen Environmental Research

2 Wageningen Economic Research

Dit onderzoek is uitgevoerd door Wageningen Environmental Research en gesubsidieerd door het ministerie van Landbouw, Natuur en Voedselkwaliteit, in het kader van het Beleidsondersteunend onderzoekthema 'Biodiversiteit in de Kringlooplandbouw' (projectnummer BO-43-104-005-WEnR).

Wageningen Environmental Research

Wageningen, september 2021

Gereviewd door:

Wim Nieuwenhuizen (Wageningen Environmental Research)

Akkoord voor publicatie:

Joke de Jong, teamleider van Biodiversiteit en Beleid

Rapport 3110

ISSN 1566-7197 
Eldik, Z.C.S. van, J. Westerink, R.M.A. Schrijver, Marijke Dijkshoorn-Dekker, J. Schütt, 2021.

Overzicht handelingsperspectieven voor beleid gericht op extensivering van de landbouw Wageningen, Wageningen Environmental Research, Rapport 3110. 54 blz.; 2 fig.; 2 tab.; 119 ref.

Overheden kunnen verschillende instrumenten inzetten om desgewenst extensivering van de landbouw mogelijk te maken en die aansluiten bij factoren die een rol spelen bij de keuzes van boeren om al dan niet te extensiveren. Dit rapport inventariseert aanbevolen handelingsperspectieven voor de overheid en identificeert gedragsfactoren die nog beperkt in beeld zijn in beleidsontwikkeling voor extensivering.

In order to stimulate extensification of agriculture, public authorities can make use of various policy instruments that target factors influencing decisions of farmers regarding the intensity of their farm. This report is an inventory of options for public policy action and identifies behavioural factors that are addressed in policy development only to a limited extent.

Trefwoorden: Gedrag, beleidsinstrumenten, kringlooplandbouw, natuurinclusieve landbouw, governance.

Dit rapport is gratis te downloaden van https://doi.org/10.18174/553886 of op www.wur.nl/environmental-research (ga naar 'Wageningen Environmental Research' in de grijze balk onderaan). Wageningen Environmental Research verstrekt geen gedrukte exemplaren van rapporten.

2021 Wageningen Environmental Research (instituut binnen de rechtspersoon Stichting Wageningen Research), Postbus 47, 6700 AA Wageningen, T 03174807 00,

www.wur.nl/environmental-research. Wageningen Environmental Research is onderdeel van Wageningen University \& Research.

- Overname, verveelvoudiging of openbaarmaking van deze uitgave is toegestaan mits met duidelijke bronvermelding.

- Overname, verveelvoudiging of openbaarmaking is niet toegestaan voor commerciële doeleinden en/of geldelijk gewin.

- Overname, verveelvoudiging of openbaarmaking is niet toegestaan voor die gedeelten van deze uitgave waarvan duidelijk is dat de auteursrechten liggen bij derden en/of zijn voorbehouden.

Wageningen Environmental Research aanvaardt geen aansprakelijkheid voor eventuele schade voortvloeiend uit het gebruik van de resultaten van dit onderzoek of de toepassing van de adviezen.

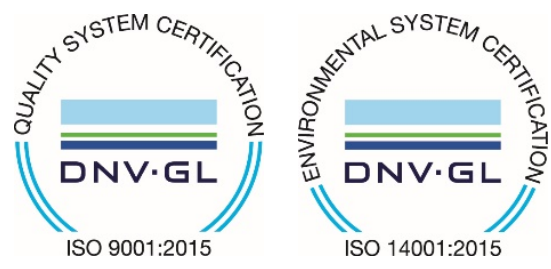

Wageningen Environmental Research werkt sinds 2003 met een ISO 9001 gecertificeerd kwaliteitsmanagementsysteem. In 2006 heeft Wageningen Environmental Research een milieuzorgsysteem geïmplementeerd, gecertificeerd volgens de norm ISO 14001.

Wageningen Environmental Research geeft via ISO 26000 invulling aan haar maatschappelijke verantwoordelijkheid.

Wageningen Environmental Research Rapport 3110 | ISSN 1566-7197

Foto omslag: Bendiks Westerink 


\section{Inhoud}

$\begin{array}{ll}\text { Verantwoording } & 5\end{array}$

$\begin{array}{ll}\text { Samenvatting } & 7\end{array}$

$1 \quad$ Inleiding $\quad 9$

1.1 Aanleiding 9

1.2 Onderzoeksvragen $\quad 9$

1.3 Concepten 9

1.3.1 Extensieve landbouw 9

1.3.2 Handelingsperspectieven voor de overheid 12

1.4 Aanpak 12

1.5 Leeswijzer 13

2

$\begin{array}{ll}\text { Raamwerk } & 14\end{array}$

2.1 Aanname: sturing beïnvloedt gedrag 14

2.2 Sturing: een scala aan instrumenten en strategieën $\quad 14$

$\begin{array}{lll}2.3 & \text { Factoren die meespelen in de keuzes van boeren } & 15\end{array}$

$\begin{array}{ll}2.3 .1 \text { Willen } & 16\end{array}$

$\begin{array}{ll}2.3 .2 \text { Kunnen } & 17\end{array}$

2.3.3 Steun van de omgeving 18

2.3.4 Effectieve sturing richt zich op alle drie en houdt rekening met
verschillen

2.4 Handelingsperspectieven: instrumenten die bijdragen aan keuzes voor
extensivering

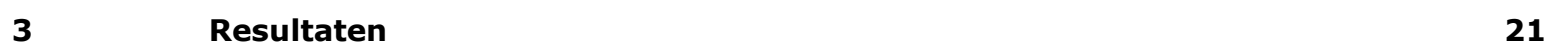

3.1 Communicatieve instrumenten $\quad 22$

3.1.1 Instrumenten die bijdragen aan willen $\quad 22$

$\begin{array}{ll}3.1 .2 & \text { Instrumenten die bijdragen aan kunnen }\end{array}$

3.1.3 Instrumenten die bijdragen aan steun van de omgeving 27

$\begin{array}{lll}3.2 & \text { Financiële instrumenten } & 30\end{array}$

3.2.1 Instrumenten die bijdragen aan willen 30

3.2.2 Instrumenten die bijdragen aan kunnen 30

3.2.3 Instrumenten die bijdragen aan steun van de omgeving 33

$\begin{array}{lll}3.3 & \text { Juridische instrumenten } & 35\end{array}$

3.3.1 Instrumenten die bijdragen aan willen $\quad 35$

3.3.2 Instrumenten die bijdragen aan kunnen $\quad 35$

3.3.3 Instrumenten die bijdragen aan steun van de omgeving 38

3.4 Hiaten: waar ontbreken handelingsperspectieven? 39

$\begin{array}{ll}3.4 .1 \text { Willen } & 40\end{array}$

$\begin{array}{ll}3.4 .2 \text { Kunnen } & 41\end{array}$

$\begin{array}{ll}3.4 .3 \text { Steun van de omgeving } & 42\end{array}$

4 Discussie $\quad 44$

4.1 Beperkingen van het onderzoek $\quad 44$

4.2 Extensivering: geen doel op zich $\quad 44$

$\begin{array}{lll}4.3 & \text { Resterende onderzoeksvragen } & 45\end{array}$ 



\section{Verantwoording}

Rapport: 3011

Projectnummer: 5200046740

Klankbordgroep:

Laura van Rossem (LNV, opdrachtgever);

Martijn van der Heide (LNV);

Peter Hilgen (LNV);

Aldert van Eck (LNV);

Tim Verhoef (LNV);

Fleur Norbruis (LNV);

Arne Meester (LNV);

Jan Maarten Dros (Wij.land);

Daan Boezeman (PBL);

Anne van Doorn (WENR);

Roel Jongeneel (WECR);

Nico Polman (WECR).

Wageningen Environmental Research (WENR) hecht grote waarde aan de kwaliteit van zijn eindproducten. Een review van de rapporten op wetenschappelijke kwaliteit door een referent maakt standaard onderdeel uit van ons kwaliteitsbeleid.

Akkoord Referent die het rapport heeft beoordeeld,

functie: Onderzoeker landelijk gebied

naam: Wim Nieuwenhuizen

datum: $\quad 26$ juli 2021

Akkoord teamleider voor de inhoud,

naam: Joke de Jong

datum: $\quad 22$ juli 2021 


\section{Samenvatting}

Voor dit rapport is een inventarisatie gemaakt van handelingsperspectieven voor beleid gericht op extensivering van de landbouw. Handelingsperspectieven worden in dit rapport beschouwd als overheidsinstrumenten die invloed kunnen uitoefenen op het willen van de boer, het kunnen van de boer en steun van de omgeving (keten, andere overheden, publieke opinie etc.), ofwel een breed scala aan factoren die een rol spelen bij keuzes van boeren om te extensiveren. Daarnaast is er een onderscheid gemaakt tussen communicatieve, financiële en juridische instrumenten. Communicatieve instrumenten zijn vaak gericht op het informeren van boeren, bijvoorbeeld middels voorlichting, onderzoek en samenwerking. Framing en nudging behoren ook tot communicatieve instrumenten, deze kunnen vooral van invloed zijn op minder bewuste keuzeprocessen. Financieel-economische instrumenten kunnen worden ingezet om boeren te prikkelen met subsidies, kortingen, beloningen of toeslagen, of juist om boeren te ontmoedigen door middel van heffingen of boetes. Juridische instrumenten kunnen worden ingezet om zaken te reguleren, randvoorwaarden te stellen of rechten af te bakenen. Niet alle instrumenten zijn even verleidelijk of even belastend. Communicatieve instrumenten zijn bijvoorbeeld vaker vrijblijvend van aard zijn en juridische instrumenten zijn over het algemeen vrij dwingend. Maar ook elke situatie voor de boer is anders. Sommige boeren voelen bijvoorbeeld meer urgentie rondom milieuproblemen of beschikken over betere (of meer) grond waardoor extensivering voor hen aantrekkelijk kan zijn. Anderen geloven dat extensivering te veel ten koste zal gaan van hun opbrengst of dat vormen van extensieve landbouw niet passen bij de culturele normen van hun groep. Effectieve sturing richt zich daarom op alle drie de gedragsfactoren (willen, kunnen, omgeving), maar houdt ook rekening met verschillen.

Voor het concept extensief zijn mogelijke indicatoren voor intensiteit/extensiteit geclusterd in categorieën: inputs, outputs en grondgebruik. Hieruit valt op te maken dat 'extensief' voor veehouderij, akkerbouw en gemengde bedrijven een andere betekenis kan hebben. Belangrijke indicatoren van extensief zijn veedichtheid, gewasrotatie en lage emissies van stikstof, fosfaat en overige broeikasgassen. Bedrijfsmodellen als kringlooplandbouw, biologische landbouw, multifunctionele landbouw of natuurinclusieve landbouw zijn vaak extensief, maar niet synoniem aan extensief.

In totaal zijn op basis van literatuurstudie 78 handelingsperspectieven verzameld; een deel daarvan wordt al in de praktijk toegepast en een deel zijn suggesties zijn uit diverse onderzoeken of toekomstvisies. Daarnaast zijn er ten minste 12 hiaten geïdentificeerd aan de hand van lege ruimtes in de inventarisatietabel en op grond van reflecties uit het onderzoeksteam.

Het meest genoemde communicatieve handelingsperspectief is het formuleren van een eenduidige en duurzame langetermijnvisie waarin alle (externe) kosten en effecten van landbouwpraktijken zijn doorberekend en geborgen. Daarnaast zijn communicatieve handelingsperspectieven vooral gericht op het stimuleren van netwerken en samenwerking. Dat kan op verschillende manieren, bijvoorbeeld in de vorm van leer- en praktijknetwerken of pilotprojecten. Daarbij wordt gestuurd op het herkennen van extensieve praktijken en op het erkennen en verder ontwikkelen van boerenvakmanschap, zodat extensief als gedeelde norm in de groep geaccepteerd kan worden. Landbouwcollectieven (zoals BoerenNatuur) en coöperaties kunnen daar een prominente rol in spelen. Niet elke boer heeft echter dezelfde leerstijl. Sommige boeren komen liever niet van hun erf af en zijn meer gebaat bij betrouwbaar advies dichter bij huis, bijvoorbeeld van onafhankelijke erfcoaches of vakbladen. Ook kan er rekening gehouden worden met verschillende behoeftes van boeren in verschillende levensfases.

Extensieve landbouw kan bijvoorbeeld als integraal onderdeel worden opgenomen in het landbouwonderwijs, en voor oudere boeren kan het mogelijk aantrekkelijk zijn om te extensiveren om hun kans op bedrijfsovername te vergroten. Samenwerking en netwerken betreft ook ketenpartijen en consumenten. Zo kunnen overheden een betrokken rol innemen bij het maken van afspraken over risicodeling of productdifferentiatie en meer korte ketennetwerken stimuleren. Consumenten kunnen 
geïnformeerd worden over de meerwaarde van extensieve landbouw en gestimuleerd worden een bewuste keuze te maken in de winkel, bijvoorbeeld met extensieve keurmerken.

Financieel-economische handelingsperspectieven kunnen boeren meer zekerheid bieden in een transitiefase. De nadruk zal meer komen te liggen op het belonen voor hun inzet in het behalen van duurzaamheidsdoelen in plaats van het maximaliseren van hun productie. Vaak worden kritische prestatie indicatoren (KPI's) in de literatuur genoemd als meetinstrument waaraan vergoedingen gekoppeld kunnen worden voor de toegevoegde waarde van extensieve landbouw, zoals biodiversiteit en een verbeterde bodem/grondwaterkwaliteit. Beloningen voor KPI's zouden kunnen dienen als (gedeeltelijke) compensatie voor gederfde inkomsten als gevolg van extensivering; dit moet echter nog in de praktijk bevestigd worden. Voor overige (omschakel)kosten kan eventueel gedacht worden aan een transitiefonds. Daarnaast kunnen financiële instrumenten helpen bij het aanschaffen van extra grond, zodat boeren bijvoorbeeld minder hoeven te krimpen in vee. Agrarische grond in Nederland is echter duur en daarom voor veel boeren een struikelblok voor extensivering. Daarbij komt ook dat geliberaliseerde pachtcontracten te weinig langetermijngarantie kunnen bieden, waardoor boeren zich niet gemotiveerd voelen om langetermijnmaatregelen te nemen. Overheden kunnen extensieve boeren ondersteunen door zelf als verpachtende partij op te treden of kunnen kortingen geven, bijvoorbeeld op waterschapsbelasting. Ook kan vervuilende intensieve landbouw ontmoedigd worden met strengere milieu- en klimaatheffingen. Subsidies kunnen boeren onder andere helpen bij hun investeringsbehoefte, maar zijn vaak van tijdelijke aard. Veranderingen in het GLB bieden op lange termijn meer houvast.

Juridische handelingsperspectieven kunnen enerzijds maatregelen zijn om boeren meer experimenteerruimte te geven, anderzijds limiterende maatregelen om praktijken die schadelijk zijn voor klimaat en milieu te beperken, zodat extensieve bedrijfsmodellen een voordeel krijgen ten opzichte van meer intensieve. Juridische handelingsperspectieven kunnen zeer ingrijpend zijn. Mitigerende beleidsmaatregelen zoals strengere emissiegrenzen kunnen cruciaal zijn om bijvoorbeeld binnen de grenzen van het Klimaatakkoord te blijven, maar zullen er ook voor zorgen dat sommige boeren zich gedwongen voelen om te stoppen. Boeren die willen extensiveren, willen graag zo min mogelijk geconfronteerd worden met administratieve processen. Dat kan onder andere door boeren meer te vertrouwen in hun vakmanschap, bijvoorbeeld als het aankomt op uiterste inzaai- of maaimomenten, en door boeren meer vrijheid te geven om alternatieven af te tasten, zoals het voeren van dieren met reststromen. Ook kunnen boeren geholpen worden door pacht voor lange termijn aan te moedigen en ketenafspraken te stimuleren die de onderhandelingspositie van boeren kunnen versterken.

Bij het inventariseren van handelingsperspectieven is ook een aantal kennislacunes (hiaten) geconstateerd. Voor het willen van de boer zijn er nog onduidelijkheden rondom relaties tussen extensivering en bedrijfsovername en tussen extensivering en de behoefte aan autonomie van de boer. Ook zijn er naar verhouding weinig sociaal-culturele handelingsperspectieven en stimulerende juridische maatregelen gevonden (ten opzichte van beperkende maatregelen). Voor het kunnen van de boer zou meer aandacht uit kunnen gaan naar sociaal kapitaal, technologie, eventuele schuldenlasten, grondmobiliteit en vergoedingen die momenteel mogelijk ten onrechte niet direct bij de boer terechtkomen. Als laatste zien we dat er in het algemeen en in de sociale omgeving van de boer nog weinig over extensivering als serieus ontwikkelpad wordt gesproken. Extensiteit is meer een bijkomstigheid van bepaalde bedrijfsmodellen. Daarop volgt de vraag in hoeverre extensivering op dit moment kan aansluiten op lokale gedragsnormen.

Bij het inventariseren van de handelingsperspectieven zijn de doelmatigheid en effectiviteit van sturingsinstrumenten niet beoordeeld. Hoe zwaar de handelingsperspectieven wegen en in welke volgorde ze uitgevoerd kunnen worden, is nog niet onderzocht. Dat enkele handelingsperspectieven zwaar kunnen wegen, lijkt echter evident. Boeren zullen die lasten daarom niet alleen kunnen dragen. De conclusie is dan ook dat het een gezamenlijke inzet vergt om extensieve landbouw te realiseren. 


\section{$1 \quad$ Inleiding}

\section{$1.1 \quad$ Aanleiding}

Extensivering van landbouwbedrijven (zie paragraaf 1.3.1) wordt gezien als een belangrijke route voor het bevorderen van biodiversiteit in de landbouwsector. Verwacht wordt dat extensieve bedrijven meer ruimte kunnen bieden aan biodiversiteit en minder belasting opleveren voor het milieu (Van den Burg et al., 2021). In de beoogde transitie richting natuurinclusieve kringlooplandbouw is het ministerie van LNV daarom onder meer geïnteresseerd in mogelijkheden om te komen tot extensivering van de landbouw. Extensivering is voor boeren geen gemakkelijke opgave. Afhankelijk van de nagestreefde 'extensiteit' vraagt het om ingrijpende tot zeer ingrijpende veranderingen in de bedrijfsvoering en bedrijfseconomie van boerenbedrijven.

Extensivering gaat daarom niet vanzelf. Omdat het huidige economische en sturingssysteem boeren vooral aanzet tot intensiveren (Vink en Boezeman, 2018) en extensiveren daardoor slechts weinigen lukt, zijn interventies van overheden en ketenpartijen nodig om tot extensivering te komen. Dit rapport inventariseert mogelijkheden daarvoor. We gebruiken de term handelingsperspectieven om concrete sturingsopties aan te duiden. Aspecten van handelingsperspectieven zijn aangestipt in diverse onderzoeken en adviezen. Een overzicht hiervan ontbreekt, waardoor onvoldoende zicht is op hiaten in de kennis met betrekking tot handelingsperspectieven.

\subsection{Onderzoeksvragen}

- Wat zijn handelingsperspectieven voor de overheid voor het stimuleren van extensivering van de landbouw?

- Welke kennislacunes bestaan ten aanzien van handelingsperspectieven voor extensivering?

\subsection{Concepten}

\subsubsection{Extensieve landbouw}

Extensivering is een ontwikkeling naar een minder intensieve landbouw, als manier om binnen de natuurlijk draagkracht van onze omgeving landbouw te kunnen bedrijven (Lesschen et al., 2020). Dat wil zeggen dat de hoeveelheid input die een boer moet leveren om een bepaalde output te realiseren, niet ten koste gaat van langdurig behoud van de kwaliteit van bodem en water en geen negatieve externaliteiten veroorzaken zoals klimaatverandering en verlies van biodiversiteit. Extensivering is dus een route die kan bijdragen aan urgente verduurzamingsopgaves zoals de stikstofcrisis en biodiversiteitsherstel (Van den Burg et al., 2021). In deze paragraaf geven we een overzicht van betekenissen van extensieve landbouw en maken we duidelijk wat we meenemen in dit onderzoek.

Extensieve landbouw kan op verschillende manieren worden gedefinieerd. In Figuur 1 zijn mogelijke indicatoren voor intensiteit/extensiteit geclusterd in categorieën: inputs, outputs en grondgebruik. Extensief betekent iets anders voor veehouderij, akkerbouw en gemengde bedrijven.

Landbouw kan extensief zijn doordat er relatief weinig inputs worden gebruikt. Dit kan gaan om stoffen die worden aangevoerd, zoals mest, veevoer en bestrijdingsmiddelen. Voor veehouderijen wordt vaak gekeken naar de veedichtheid. Dit wordt meestal uitgedrukt in een gestandaardiseerde maat voor het aantal dieren per hectare, zoals GVE (grootvee-eenheid). Zo kunnen bedrijven met verschillende aantallen melkkoeien, jongvee en schapen toch worden vergeleken. Een hoge veedichtheid per hectare betekent dat er relatief veel voer moet worden aangevoerd en er veel mest beschikbaar is. Daarom kan 
grondgebondenheid in de zin van ofwel een hoog aandeel voer van eigen land, ofwel voldoende land voor de geproduceerde mest, een kenmerk zijn van extensieve bedrijven. Ook een biologische productiewijze heeft een relatie met extensiteit, omdat daarin geen kunstmest en bestrijdingsmiddelen zijn toegestaan en er geen derogatie is toegestaan die tot meer ruimte leidt voor toediening van dierlijke mest per hectare, zodat de veedichtheid in de regel lager is dan bij gemiddelde gangbare veebedrijven.

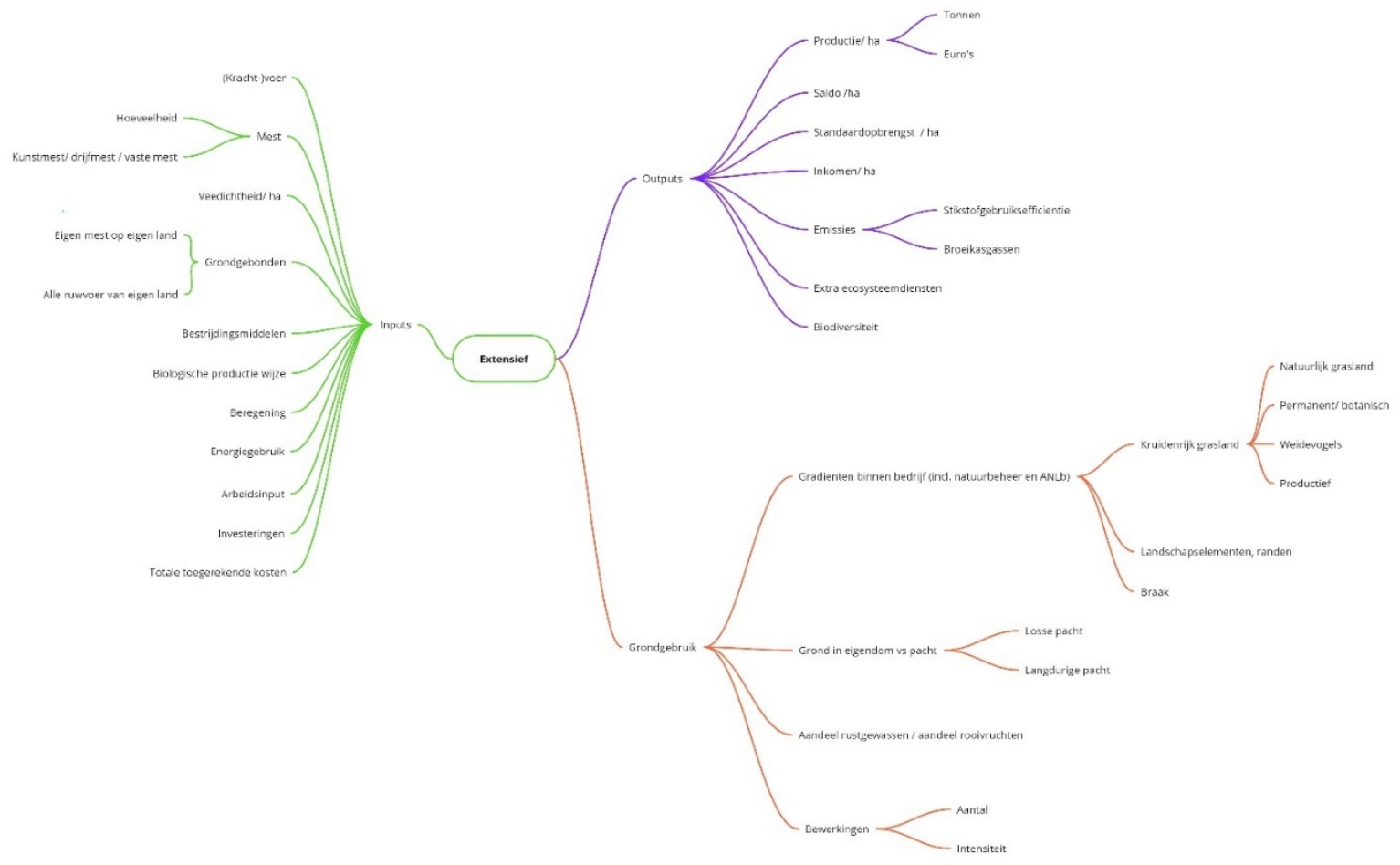

Figuur 1 Mogelijke indicatoren voor extensieve landbouw.

Inputs kunnen ook betrekking hebben op beregening, energie, investeringen en arbeid. Teelten die kwetsbaar zijn voor droogte en veel moeten worden beregend, leggen een relatief groot beslag op het grondwater. Ook kost beregening veel energie. Vormen van niet-kerende grondbewerking kosten minder energie dan ploegen. Lichtere machines hebben de voorkeur. Er zijn echter wel trade-offs: een lagere input aan bestrijdingsmiddelen kan leiden tot een hogere input aan energie en arbeid doordat meer bewerkingen nodig zijn. En veel handwerk bespaart energie, maar vraagt veel arbeid. Totale toegerekende kosten zijn een indicator om alle inputs op geld te zetten en op te tellen.

Landbouw kan ook extensief zijn doordat de productie relatief laag is (outputs). Dat kan gaan om de tonnen product per hectare, maar ook om de geldelijke waarde daarvan, of het saldo (opbrengsten minus kosten). De standaardopbrengst per hectare is een veelgebruikte maat voor intensiteit. Dit gaat om de omzet die verband houdt met het voedselproduct. Dit is nog niet hetzelfde als de totale inkomsten per ha, want een bedrijf kan meerdere inkomstenbronnen hebben, zoals agrarisch natuurbeheer, kaasbereiding, huisverkoop en andere nevenactiviteiten die niet in de standaardopbrengst zijn opgenomen.

Behalve de opbrengst van het voedselproduct zijn er nog meer outputs die iets zeggen over de intensiteit. Extensieve bedrijven hebben lage emissies aan stikstof (ammoniak, nitraat), fosfaat en broeikasgassen per ha. Tegelijkertijd hebben extensieve bedrijven een grotere output aan ecosysteemdiensten anders dan voedsel: ze leveren een groter aantal ecosysteemdiensten en met een hoger leveringsniveau. Ook biodiversiteit kan als output worden beschouwd.

Inputs en outputs houden uiteraard verband met elkaar. Die relatie is echter niet een-op-een. Vakmanschap en bedrijfsvoering spelen daarin een grote rol. Extensieve veebedrijven maken vaker 
gebruik van robuuste dubbeldoelrassen met een lagere melkproductie per koe. Intensieve akkerbouwbedrijven hebben vaker gewassen waarbij hoge stikstofverliezen moeilijk te vermijden zijn. Tegelijkertijd kan met vakmanschap wel degelijk gestuurd worden op bijvoorbeeld stikstofgebruiksefficiëntie (benutting).

De categorie grondgebruik richt de aandacht op variatie binnen het bedrijf van intensievere en extensievere vormen van landgebruik in ruimte en tijd. Voor akkerbouwbedrijven is het bijvoorbeeld relevant om te kijken naar de gewasrotatie en het bouwplan, en met name de verhouding rooi- en rustgewassen. Rooigewassen vragen veel inputs en dragen bij aan afbraak van organische stof in de bodem: rustgewassen voegen organische stof toe. Voor veehouderijen is het relevant om te kijken naar het aandeel kruidenrijk grasland. Permanent kruidenrijk grasland is meestal vrij extensief met een hogere biodiversiteitswaarde, terwijl ingezaaid tijdelijk kruidenrijk grasland met een beperkte biodiversiteitswaarde vrij intensief kan worden beheerd. Extensief kan betekenen dat een bedrijf relatief veel randen, landschapselementen, braak of natuurgrond binnen het bedrijf heeft. Een andere maat voor intensiteit kan het aantal en de intensiteit van de bewerkingen zijn. Tot slot kan de grondpositie van een bedrijf iets zeggen over de intensiteit. Land dat slechts korte tijd wordt gehuurd, wordt vaak zeer intensief gebruikt.

\section{Kader: handelingsperspectieven voor de boer om te extensiveren}

Diverse concepten geven vorm aan handelingsperspectieven voor boeren om te extensiveren, zoals:

1. Kringlooplandbouw: minder inputs en sturing op een efficiëntere kringloop voor betere mest- en bodemkwaliteit en minder verliezen. Verdienmodel: lagere kosten (Holster et al., 2014, Erisman en Verhoeven, 2019).

2. Boeren voor Natuur: gemengd bedrijf, geen aanvoer van mest en voer, hogere waterstanden, $10 \%$ landschapselementen. Verdienmodel: langjarige betaling (Westerink et al., 2013; 2018a).

3. Biologisch: geen kunstmest, geen chemische bestrijdingsmiddelen, geen derogatie, zo min mogelijk antibiotica, weidegang. Bevorderen bodemvruchtbaarheid en natuurlijke processen. Verdienmodel: biologische productprijs.

4. Agro-ecologische, regeneratieve of herstellende landbouw: gebruikmaken en bevorderen van natuurlijke processen, gericht op herstel van een goed functionerend agro-ecosysteem, waaronder de bodem. Verdienmodel: wordt vaak gezocht in biologisch en/of lokale afzet. In ontwikkeling: betaling voor ecosysteemdiensten (Erisman en Slobbe, 2020; Duncan et al., 2021).

5. Grasgevoerd: minimaliseren aanvoer van krachtvoer, optimaliseren van beschikbaar gras (Erisman et al., 2017; Heublein et al., 2017; Hoekstra et al., 2020).

6. Kruidenrijk grasland: grotere diversiteit aan planten door verschraling en/of inzaaien. Verdienmodel: agrarisch natuurbeheer (Schippers et al., 2012).

7. Natuurbeheer: pachten van natuurgrond en/of afwaardering van landbouw- naar natuurgrond. Verdienmodel: lagere grondkosten, natuurbeheervergoeding (Westerink et al., 2019c).

8. Agroforestry en voedselbossen

(Meer over verdienmodellen van extensieve landbouw: Schrijver et al., 2021.)

Natuurinclusief en extensief zijn geen synoniemen. Afhankelijk van de definitie van extensief, heeft een extensief bedrijf potentie om een bijdrage te leveren aan biodiversiteit. Bovendien ligt het voor de hand dat een extensief bedrijf gebruikmaakt van natuurlijke processen. Maar er zijn ook tamelijk intensieve bedrijven met veel biodiversiteit. In dit onderzoek hebben we gekozen voor een benadering van extensief, die wel per definitie ook natuurinclusief is.

In een eerder onderzoek kozen we voor de input van stikstof als belangrijk kenmerk van extensieve bedrijven (Agricola et al., 2021). Voor het zoeken naar handelingsperspectieven voor de overheid voor het stimuleren van extensivering hebben we echter geen strikte afbakening gehanteerd van 'extensieve landbouw'. We hebben in de literatuur gezocht naar aanbevelingen voor het bevorderen van kringlooplandbouw, biologische landbouw, natuurinclusieve landbouw, multifunctionele landbouw en het terugdringen van stikstofemissies door extensivering (zie paragraaf 1.4). Wel beperkt dit rapport zich tot vormen van landbouw die grondgebonden zijn of kunnen worden: akkerbouw, vollegrondstuinbouw, veehouderij en gemengde bedrijven. 


\subsubsection{Handelingsperspectieven voor de overheid}

Dit onderzoek gaat over het stimuleren van extensieve vormen van agrarische bedrijfsvoering. We focussen echter niet op wat de boer kan doen om zijn of haar bedrijf te extensiveren (handelingsperspectieven van de boer, zie het kader in de vorige paragraaf), maar op wat de overheid kan doen. Deze handelingsperspectieven van de overheid relateren we aan wat de boer nodig heeft om te willen en kunnen extensiveren.

Sturing is vaak gericht op het beïnvloeden van keuzes van anderen. In het geval van extensivering wil de overheid uiteindelijk de keuzes van boeren beïnvloeden, eventueel via andere partijen. Bij keuzes van boeren om wel of niet te extensiveren, spelen diverse factoren een rol: psychologische, sociaalculturele en bedrijfseconomische factoren; kennis en technologie; beperkingen van het landschap; en de kansen en (on)mogelijkheden die worden geschapen door markt en beleid (Runhaar et al., 2017). Om de boer te helpen veranderen, ligt het voor de hand om sturing aan te sluiten bij de factoren die bij keuzes van boeren een rol spelen. Deze factoren bieden dus aanknopingspunten voor handelingsperspectieven voor beleid. Handelingsperspectieven betreffen:

- Aanpassing van bestaand beleid dat effect heeft op de keuzes van boeren;

- Nieuw beleid gericht op boeren;

- Nieuw beleid gericht op de omgeving van boeren die extensiveringskeuzes van boeren mede beperkt of mogelijk maakt.

Bekeken vanuit de factoren die een rol spelen bij de keuzes van boeren is het handelingsperspectief van de overheid breed en divers. Deze manier van kijken kan helpen bij het maken van een overzicht van mogelijke handelingsperspectieven. Ook kan het helpen om inzichtelijk te maken waar nog mogelijkheden zijn die nu nog niet worden benut.

We richten ons in dit onderzoek niet op instrumenten die gericht zijn op het verkleinen van het aantal boerenbedrijven, zoals opkoopregelingen. Ook laten we handelingsperspectieven buiten beschouwing die vooral op de overheid zelf gericht zijn, zoals aanbevelingen voor ruimtelijke zonering of algemene aanbevelingen voor het begeleiden van transitie (zie daarvoor bijvoorbeeld Runhaar et al., 2020).

\subsection{Aanpak}

Voor dit onderzoek is gekozen voor een literatuurstudie. Hiervoor is een uitgebreide scan van literatuur uitgevoerd ten aanzien van extensivering in de onlinedatabase van de bibliotheek van Wageningen University en Research, aangevuld met bronnen die binnen het onderzoeksteam bekend waren. De geraadpleegde literatuur bestaat uit onderzoeksrapporten, wetenschappelijke artikelen, vakliteratuur en overheidsbrochures. Hierin is specifiek gezocht naar handelingsperspectieven voor de overheid, bijvoorbeeld in de vorm van aanbevelingen voor beleid. De gevonden handelingsperspectieven zijn verzameld in een Excelbestand. In dit bestand zijn de handelingsperspectieven verticaal geordend naar de beoogde invloed op de boer: willen, kunnen en omgeving. Horizontaal zijn de handelingsperspectieven ingedeeld naar het soort beleidsinstrumenten: communicatie, financieel en juridisch. In het raamwerk in hoofdstuk 2 worden deze categorieën toegelicht. Vanuit het totale overzicht van handelingsperspectieven is vervolgens een inventarisatie gemaakt in welke categorieën nog handelingsperspectieven ontbreken of zijn ondervertegenwoordigd. Hierbij is vooral gekeken naar gedragsfactoren die nu nog niet of nauwelijks worden geadresseerd in aanbevolen handelingsperspectieven. $\mathrm{Er}$ is in het onderzoek geen beoordeling gemaakt van de gevonden handelingsperspectieven. 


\subsection{Leeswijzer}

Hoofdstuk 2 beschrijft het raamwerk dat we hebben gebruikt om handelingsperspectieven voor de overheid om extensivering van landbouwbedrijven te bevorderen, te analyseren. Dit raamwerk koppelt verschillende beleidsinstrumenten aan factoren die meespelen in keuzes van boeren.

Hoofdstuk 3 bevat de resultaten van de literatuurstudie in de vorm van een overzicht van handelingsperspectieven en hiaten met betrekking tot aanbevolen opties voor de overheid om extensivering te stimuleren.

In hoofdstuk 4 bespreken we de beperkingen van dit onderzoek en resterende onderzoeksvragen. Hoofdstuk 5 bevat de conclusies en aanbevelingen. 


\section{Raamwerk}

\subsection{Aanname: sturing beïnvloedt gedrag}

De grote aanname van beleid is dat beleid invloed heeft op het gedrag van mensen. Bewust of onbewust ligt onder beleid een beleidstheorie ten grondslag met aannames over de manier waarop het beleid en de gekozen instrumenten bijdragen aan beoogde doelen en de oplossing van problemen (De Graaf en Hoppe, 1996). Overheidsbeleid dat zich richt op het verduurzamen van de landbouw richt zich uiteindelijk (eventueel via bijvoorbeeld ketenpartijen) op de boer. Op de boerderij is het echter de boer die de keuzes maakt. Tenzij de boer wordt onteigend, is sturing beperkt tot beïnvloeding van de keuzes van de boer. Ook de effectiviteit van regelgeving is afhankelijk van naleving. Gedrag is bepalend.

In diverse beleidsdomeinen is daarom een groeiende interesse in gedragswetenschappen (Jones et al., 2013). Een beter begrip van gedrag kan helpen verklaren waarom bepaalde beleidsinterventies wel of niet effectief zijn. Het kan ook helpen om beter beleid te ontwerpen, door gedrag onderdeel te maken van de beleidstheorie. Beleid moet dan ingrijpen op en rekening houden met factoren die het gewenste gedrag hinderen of mogelijk maken.

De overheid is niet de enige die invloed heeft op de keuzes van boeren. Daarom spreken wij hier ook van sturing (governance). Sturing omvat ook beleid van bijvoorbeeld ketenpartijen en terreinbeherende organisaties, en manieren waarop overheid en private partijen elkaar beïnvloeden en met elkaar samenwerken. Tot de handelingsperspectieven van de overheid behoren immers ook mogelijkheden voor het beïnvloeden van partijen die invloed hebben op de boer.

\subsection{Sturing: een scala aan instrumenten en strategieën}

In dit rapport inventariseren we mogelijke handelingsperspectieven van de overheid als (combinaties van) instrumenten. In de analyse maken we gebruik van de gangbare indeling naar communicatieve, financiële en juridische instrumenten (zie bijvoorbeeld Westerink et al., 2009). Volgens de zogenaamde interventieladder grijpen communicatieve instrumenten beperkt in op de keuzevrijheid, financiële instrumenten grijpen al meer in, en juridische instrumenten zijn nog dwingender (NCB, 2007).

Voorbeelden van communicatieve instrumenten zijn voorlichting, onderzoek, samenwerking, prijsvragen en allerlei vormen van framing en nudging. Voor gedragsbeïnvloedingstechnieken uit de Behavioural Insights zoals nudging is de laatste tijd veel belangstelling (RMO 2014, BIN-NL 2019). Deze richten zich vooral op onbewuste, niet-rationele keuzeprocessen.

Financieel-economische instrumenten kunnen worden ingezet om gewenst gedrag te stimuleren met positieve prikkels of om ongewenst gedrag te ontmoedigen met negatieve prikkels. Stimuleren kan met bijvoorbeeld subsidies voor bepaalde inspanningen, betalingen voor resultaten, compensatie, toeslagen en heffingskortingen. Een bijzondere mogelijkheid in relatie tot landbouw is het beschikbaar stellen van grond tegen een gunstig pachttarief. Ontmoedigen kan met bijvoorbeeld accijns, heffingen, kortingen op subsidies en boetes.

Juridische instrumenten kunnen worden ingezet om markten te reguleren of te creëren, randvoorwaarden te stellen of rechten af te bakenen. Fosfaatrechten en quota zijn voorbeelden van marktregulering. Randvoorwaarden kunnen de vorm hebben van voorschriften of verbodsbepalingen. Eigendomsrechten en vergunningen zijn voorbeelden van het afbakenen van rechten. 
De categorieën van instrumenten zijn onderling niet heel scherp afgebakend. Een subsidieregeling kent bijvoorbeeld meestal allerlei voorwaarden en bij de werving van deelnemers worden communicatieve instrumenten ingezet. Een sturingsstrategie bestaat bovendien vaak uit een combinatie van instrumenten. Het bevorderen van biodiversiteit in een bepaald gebied kan bijvoorbeeld de vorm krijgen van een gebiedsproces (communicatie) in combinatie met kavelruil (communicatief + financieel-economisch), een verbod op het gebruik van bestrijdingsmiddelen in het Omgevingsplan (juridisch) en een subsidie voor maatregelen op landbouwgrond (financieel-economisch + juridisch).

Een dergelijke instrumentenmix kan vaak sterker worden als andere partijen mee gaan sturen. Uitkomst van het gebiedsproces kan bijvoorbeeld zijn dat een terreinbeherende organisatie bepaalde vormen van landbouw gaat bevorderen door het selectief uitgeven van pachtgronden (denk aan de pilot

Natuurinclusieve Landbouw van Staatsbosbeheer ${ }^{1}$ ). Of dat private partijen bijdragen aan het stapelen van beloningen (Silvis et al., 2021). Om andere partijen te bewegen om mee te gaan sturen, kan de overheid eveneens communicatieve, financieel-economische en juridische instrumenten inzetten.

Het ontwerpen van een goede instrumentenmix gaat niet alleen over het ontwikkelen van nieuwe instrumenten. Het is vaak even belangrijk om te bezien waar bestaande instrumenten de gewenste ontwikkelingen hinderen. Het kan dus ook gaan om aanpassing en soms afschaffing van bestaande instrumenten.

In navolging van Michie et al. (2011) gaan wij ervan uit dat verschillende (combinaties van) instrumenten kunnen worden ingezet met het oog op specifieke gedragsfactoren. Op deze gedragsfactoren gaan wij nu in.

\subsection{Factoren die meespelen in de keuzes van boeren}

In de literatuur worden zeer veel factoren beschreven die meespelen in de keuzes van boeren met betrekking tot milieu en biodiversiteit. Op basis van Runhaar et al. (2017: willen, kunnen, moeten en mogen, zie ook Westerink et al 2018b) en Mills et al. (2016: willen, kunnen en betrokkenheid) hebben Westerink et al. (2020) dit samengevat als willen, kunnen en steun van de omgeving ${ }^{2}$ (Figuur 2). Een boer moet willen, kunnen en steun ondervinden uit de omgeving voordat hij of zij zal overgaan tot extensivering van het bedrijf.

We gaan nu wat dieper in op de diverse gedragsfactoren binnen de categorieën willen, kunnen en steun van de omgeving. We maken daarbij gebruik van verschillende gedragstheorieën die deels andere factoren benadrukken. Op deze manier geven we aandacht aan zowel bewuste als onbewuste en zowel rationele als niet-rationele factoren. Rationele, bewuste afwegingen zijn belangrijk bij keuzes op het boerenbedrijf: kan deze investering zichzelf terugverdienen? Past dit gewas bij deze bodem? Maar evenzeer spelen onbewuste en niet-rationele factoren een rol, zoals gewoonte en zelfvertrouwen. Onderstaande paragrafen bieden geen compleet overzicht van gedragsfactoren, maar wel een kapstok voor een breed scala aan factoren die een rol spelen in de keuzes van boeren. Andere overzichten zijn te vinden in Dessart et al. (2019), Siebert et al. (2006), Mills et al. (2016), Schoonhoven and Runhaar (2018) en Prokopy et al. (2008).

Iedere factor heeft een positieve en een negatieve kant van de medaille: afhankelijk van de boer en de situatie kan het een kans zijn of een barrière. Hoge grondkosten zijn bijvoorbeeld een barrière voor extensivering, lage grondkosten maken extensivering mogelijk.

\footnotetext{
1 https://www.staatsbosbeheer.nl/Over-Staatsbosbeheer/Dossiers/natuurinclusieve-landbouw https://www.wur.nl/nl/Onderzoek-Resultaten/Onderzoeksprojecten-LNV/Expertisegebieden/kennisonline/Monitoring-SBBexperimenten.htm

2 Dit komt sterk overeen met de categorieën van Michie et al. (2011): willen, kunnen en gelegenheid. Deze drieslag is geïnspireerd op strafzaken (means, motive, opportunity) en eerst ontwikkeld met het oog op patiëntengedrag. Gelegenheid wordt geschapen door de omgeving. Gezien de grote invloed van de omgeving op de keuzeruimte van boeren (Runhaar et al., 2020) vinden wij steun van de omgeving de lading beter dekken dan gelegenheid.
} 


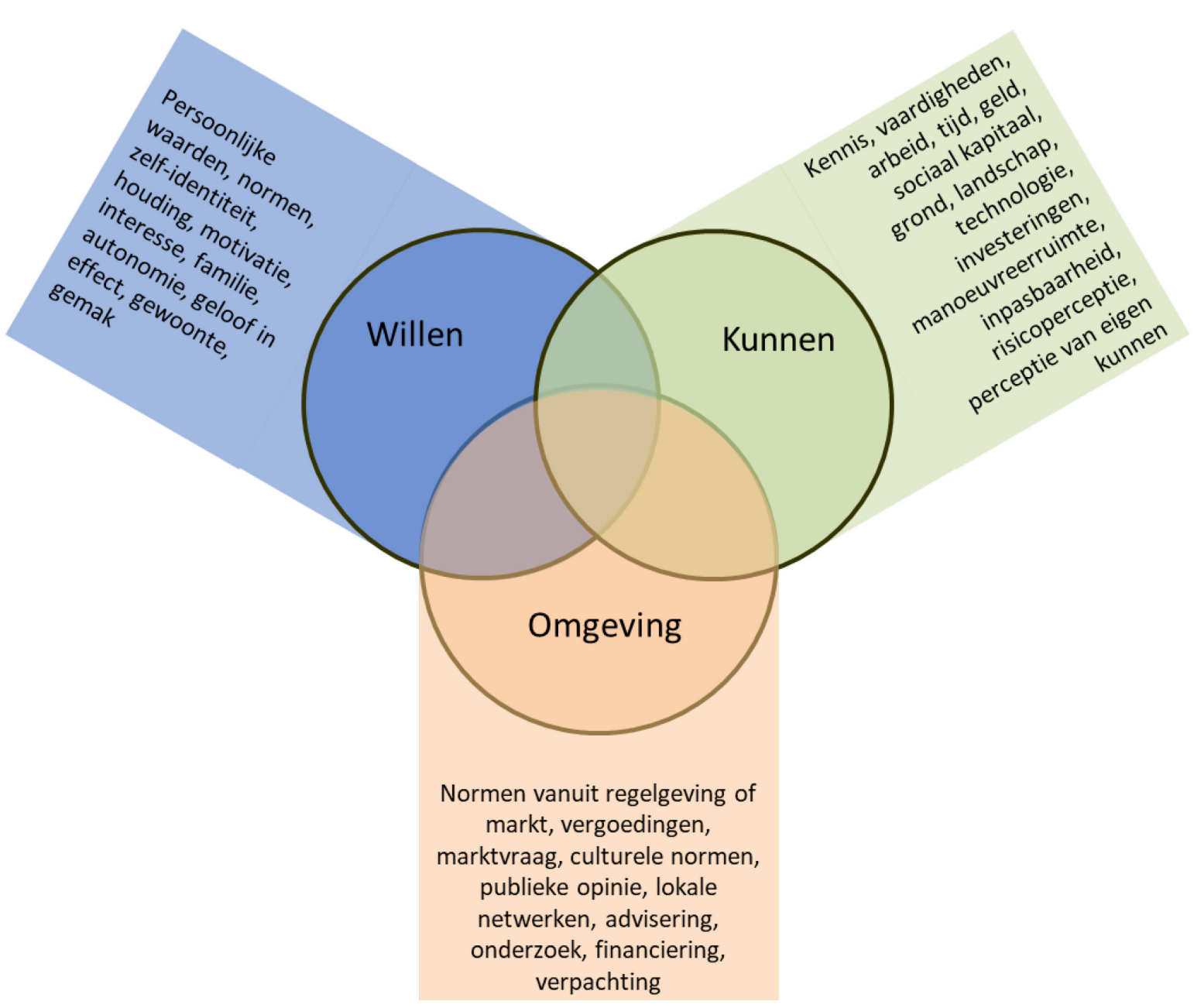

Figur 2 Categorieën van factoren die invloed hebben op de keuzes van boeren ten aanzien van extensivering. Op basis van Westerink et al., 2020.

\subsubsection{Willen}

Willen kan ook omschreven worden als motivatie of bereidheid om iets te doen. Volgens de Value Belief Norm Theory zijn onderliggende waarden bepalend voor keuzes (bijv. Johansson et al., 2013). Dit kan gaan over waarden zoals goed zorgen voor het milieu en je dieren, de uitdaging van het ondernemerschap en het doorgeven van het familiebedrijf aan de volgende generatie (Westerink et al., 2019a; Farmar-Bowers en Lane 2009). Boeren is een levensstijl waarbij plezier in het werk een belangrijke motivator is (Mills et al., 2016; Westerink et al., 2018b). De diepste drijfveren van boeren hebben te maken met hoe zij zichzelf zien als onderdeel van het grote geheel, hun visie op leven en dood, en vaak hun relatie tot het goddelijke (Mertens en Blommestein, 2004). Waarden vertalen zich volgens de Value Belief Norm Theory in overtuigingen ten aanzien van bijvoorbeeld de urgentie van milieuproblemen en die vertalen zich weer in persoonlijke normen ten aanzien wat goed of slecht is om te doen.

Persoonlijke of morele normen maken ook onderdeel uit van de Theory of Planned Behaviour (bijv. Wauters et al., 2017). Volgens hun versie komt intentie met name voort uit zelfidentiteit en persoonlijke morele normen. Zelfidentiteit en persoonlijke normen hebben een relatie met houding. Houding of attitude is iemands opstelling ten aanzien van iets. Iemand kan bijvoorbeeld openstaan voor nieuwe technieken, samenwerking of biodiversiteit, of juist niet. Houding kan dus bijvoorbeeld gaan om affiniteit met de natuur, waardoor een boer open staat voor het nemen van bepaalde maatregelen.

Zelfidentiteit betreft hoe de boer zichzelf ziet als goede boer, en als iemand die iets wel of niet zou doen (Burton, 2004; Lokhorst, 2011). Zelfidentiteit van boeren gaat over een bepaalde interpretatie van vakmanschap. Dit komt onder meer tot uiting in hoe de boer het land beheert. Het landschap is de plek 
waar boeren een deel van hun vakmanschap ten toon spreiden (Burton et al., 2008; Westerink et al., 2019b). Als extensieve landbouw bijvoorbeeld productief ogende graslanden moeilijk haalbaar maakt, kan dat conflicteren met de zelfidentiteit van sommige boeren. Zo'n boer kan dan niet meer trots zijn op zichzelf. Zelfidentiteit uit zich dus ook in persoonlijke normen ten aanzien van wat goed of slecht is om te doen als goede boer.

Voor veel boeren zijn de uitdagingen van het ondernemerschap, vrijheid en autonomie belangrijke waarden (Jongeneel et al., 2008; Westerink et al., 2018b). Als een keuze voor extensivering betekent dat vrijheid en autonomie worden ingeperkt, werkt dat demotiverend. Veel boeren hebben dan ook een afkeer van bureaucratie.

Niet de zin ergens van (in) zien, is een reden om ergens niet voor te kiezen (Wilson en Hart, 2000). Wat wel motiveert, is geloof dat de keuze ook het gewenste resultaat gaat opleveren (Schroeder et al., 2015; Mills et al., 2016). Dat geloof kan worden opgebouwd door het zien van resultaten bij zichzelf of anderen. Het opdoen van ervaring kan dus helpen (Westerink et al., 2019b). Ingesleten gewoontes ('ik doe het altijd zo') kunnen echter zorgen voor onbewuste keuzes en routines die verduurzaming in de weg kunnen staan (Farmar-Bowers en Lane, 2009).

\subsubsection{Kunnen}

Kunnen betreft een scala aan fysieke, cognitieve en bedrijfseconomische randvoorwaarden voor verandering. Het landschap kan bijvoorbeeld intensief landgebruik moeilijk maken door een hoog waterpeil of een minder vruchtbare bodem (Siebert et al., 2006; Ingram et al., 2013). Een tekort aan grond 'dwingt' tot intensief gebruik en/of aanvoer van veel voer. Een slechte verkaveling bemoeilijkt beweiden, terwijl beweiden voor extensieve bedrijven vaak logisch is vanwege de lagere kosten (Booij, 2015). Technologie kan extensivering ondersteunen, maar de huidige technologie is vaak nog gericht op intensivering. Er is bijvoorbeeld nog nauwelijks geschikt materieel voor strokenteelt en insectenvriendelijk maaibeheer.

Een belangrijk deel van het kunnen betreft het bedrijfssysteem. Gangbare melkveehouders zeggen tot ongeveer 20-25\% beheersgras te kunnen inpassen in het rantsoen en dit blijkt ook uit rantsoenproeven (Westerink et al., 2018b; Sanders et al., 2013; Duinkerken et al., 2005). Als het meer zou worden, gaat de melkproductie achteruit, blijven de koeien niet gezond en/of stijgen de kosten. Extensivering van de melkveehouderij binnen het huidige bedrijfssysteem kent dus een grens. Om meer beheersgras te kunnen inpassen, is een robuuster veeras nodig en moet een lagere melkproductie worden geaccepteerd. Binnen het bedrijf hangt alles samen: veeras, graslandbeheer, bodem, bemesting, melkproductie etc.

Extensivering voorbij de grens vraagt om aanpassing van het bedrijfssysteem en een ander verdienmodel. Ook in de akkerbouw gaat het om een samenhangend bedrijfssysteem. Onder andere bemesting, grondbewerking, organischestofgehalte van de bodem, vochtvasthoudend vermogen, uitspoeling, bouwplan, weerbaarheid en ziektedruk hangen met elkaar samen.

Omdat alles met elkaar samenhangt binnen het bedrijf, zijn grote veranderingen in het bedrijfssysteem niet van de ene op de andere dag gemaakt. $\mathrm{Er}$ is een bepaalde padafhankelijkheid op basis van keuzes en investeringen uit het verleden (Jongeneel et al., 2008; Vink \& Boezeman, 2018). Het kost tijd om de bodem te verschralen dan wel om organischestofgehalten te verhogen. Uit een ligboxenstal komt drijfmest en geen ruige stalmest. Extensivering kan forse nieuwe investeringen vragen: een ander staltype, een compostplaat, machines voor niet-kerende grondbewerking. Daarbij komt dat dergelijke grote veranderingen vragen om nieuw vakmanschap, terwijl het vertrouwen van de boer in eigen kunnen medebepalend is in dit soort keuzes (perceived behavioural control, onderdeel van de Theory of Planned behaviour, zie Wouters et al., 2017). Kunnen heeft dus ook een psychologische component. De boer moet bijvoorbeeld voor zichzelf manoeuvreerruimte zien (Methorst, 2016). Vergelijkbaar is de risicoperceptie van de boer: een keuze voor of tegen extensivering wordt meer bepaald door hoe de boer de risico's inschat dan door het daadwerkelijke risico (Dessart et al., 2019). Alles bij elkaar is het niet verbazingwekkend dat grote bedrijfsbeslissingen slechts enkele malen tijdens de carrière van de boer worden genomen (Farmar-Bowes en Lane, 2009).

Bedrijfseconomische overwegingen spelen uiteraard een grote rol. Extensieve bedrijfsvoering kent elementen die extra tijd kosten en die tijd opleveren. Meer grond onder het bedrijf betekent ook meer 
onderhoud (Westerink et al., 2019c). Van de huidige extensieve bedrijven is een relatief groot deel verbreed en/of klein (parttime en hobbybedrijven): hier is tijd voor andere activiteiten (Agricola et al., 2021). Een deel van deze bedrijven is extensief, omdat het inkomen uit de landbouw niet nodig is; een ander deel is verbreed, omdat het inkomen uit de landbouw te laag is voor een toekomstbestendig bedrijf. Lagere opbrengsten, en daarmee vaak lagere inkomsten, zijn een belangrijke zorg voor boeren bij een overweging tot extensivering van (delen van) hun bedrijf (Wilson en Hart, 2000; Wauters et al., 2017). Het verdienmodel moet uiteindelijk wel kloppen: tegenover lagere opbrengsten moeten lagere kosten en/of hogere (of aanvullende) inkomsten staan (Jongeneel, 2020; Polman en Dijkshoorn (eds), 2019). In relatie tot extensivering speelt grond in het economische plaatje een sleutelrol. Hoge grondkosten zijn een belemmering voor extensivering (Westerink et al., 2018b).

Tot slot heeft een boer de juiste kennis en vaardigheden nodig om extensief te kunnen boeren. De kennis en vaardigheden van een boer zijn medebepalend voor zijn of haar beoordeling van de passendheid en haalbaarheid van een ontwikkelingsrichting (Farmar-Bowers and Lane, 2009). Kennis van het probleem en hoe de maatregel kan bijdragen aan de oplossing kan ook helpen motiveren (Johansson et al., 2012) (zie vorige paragraaf). Sociaal kapitaal, ofwel de kwaliteit van relaties, kan een boer helpen om kosten te drukken en om kennis op te doen: goede relaties met collega's kunnen het bijvoorbeeld vanzelfsprekend maken om elkaars machines te lenen, elkaar te helpen bij piekwerkzaamheden en van elkaar te leren (Sutherland en Burton, 2011; Westerink et al., 2019b).

\subsubsection{Steun van de omgeving}

De omgeving van de boer, in de vorm van o.a. familie, collega's, erfbetreders, ketenpartijen, burgers, publiek en overheid, heeft invloed op het willen en het kunnen van de boer. Dat gebeurt door directe invloed en doordat de omgeving onderdeel uitmaakt van 'het systeem', dat bepaalde keuzes beperkt of mogelijk maakt.

De naaste familie heeft grote invloed op de keuzes van de boer (Farmar-Bowers and Lane, 2009). Dit geldt in het bijzonder voor de partner en de vorige generatie (Mills et al., 2016; Westerink et al., 2018b).

Collega's hebben via culturele normen behoorlijk wat invloed op de zelfidentiteit (onderdeel van het willen) (Burton et al., 2008; Westerink et al., 2019b). Hoe boeren naar zichzelf kijken als goede boer en naar een manier van landbouw die bij hen past, meten zij immers af aan cultureel kapitaal, ofwel heersende normen van goede landbouwpraktijk binnen de boerengemeenschap. Boeren leren van elkaar: sociaal en cultureel kapitaal binnen (studie)groepen, collectieven en netwerken kan de drempel verlagen of verhogen om te gaan extensiveren. Als extensieve landbouw niet als goede landbouw wordt gezien, bijvoorbeeld omdat productiviteit de heersende norm is, kan extensivering leiden tot verlies aan respect van collega's of tot verlies aan zelfrespect. Dit komt overeen met de invloed die Wauters et al. (2017) zien van normen binnen de groep op persoonlijke normen.

Daarnaast worden persoonlijke normen volgens Wauters et al. (2017) beïnvloed door heersende normen in de maatschappij. Boeren zijn gevoelig voor wat zij ervaren als kritiek in bijvoorbeeld de media. Een deel van de boeren wordt erdoor aan het denken gezet over verduurzaming, terwijl een ander deel juist in de verdediging gaat (Mills et al., 2016; Siebert et al., 2006; Westerink et al., 2018 b). Boeren die zelf veel direct contact met burgers hebben, staan vaak meer open voor alternatieve vormen van landbouw, voelen zich meer gesteund en vinden gemakkelijker alternatieve inkomstenbronnen zoals huisverkoop (De Krom, 2017; Mills et al., 2016; Van Herzele et al., 2013).

Een keuze voor extensivering wordt niet altijd bevorderd of gesteund door de adviseurs van de boer. Deze erfbetreders, zoals leveranciers van veevoer of bestrijdingsmiddelen, veeartsen, accountants en zelfs onafhankelijke adviseurs, ontbreekt het vaak aan kennis van extensieve bedrijfsvoering. Zij zullen geneigd zijn te vertrouwen op de kennis die ze hebben. Daarnaast hebben met name leveranciers van veevoer, kunstmest, bestrijdingsmiddelen en bepaalde vormen van mechanisatie commercieel belang bij intensieve landbouw. Van hen kan niet verwacht worden dat ze extensivering bevorderen. Zij zullen het eerder afraden. 
Ook banken zien vaak grote risico's, deels door onbekendheid, maar ook door wat al onder 'kunnen' benoemd is als lagere opbrengsten, afschrijving van eerdere investeringen en benodigde nieuwe investeringen. Banken hebben, evenals boeren, zicht nodig op een bestendig verdienmodel. Toch kunnen banken ervoor kiezen om bij te dragen aan de transitie, onder meer door te kiezen dergelijke risicovolle bedrijfsmodellen toch te financieren, bijvoorbeeld met rentekorting. Daarvoor is het belangrijk dat ze een visie ontwikkelen op verduurzaming van de landbouw en hun rol daarin.

Afnemers zoals zuivelcoöperaties en frietbedrijven kunnen net als banken stimulerend en remmend werken op extensivering. Aan de ene kant zijn voor hen toeleveranciers met een hoge productie gunstig, want dat werkt efficiënt. Bij sommige zuivelcoöperaties is de melkprijs hoger voor leden die veel melk leveren. Aan de andere kant werken diverse afnemers met duurzaamheidsprogramma's die hun toeleverende boeren belonen voor allerlei verduurzamingsprestaties, uitgedrukt in kritische prestatie-indicatoren (KPI's). Het nemen van verduurzamingsmaatregelen leidt dan tot een hogere productprijs voor de boer. Sommige van deze KPI's ondersteunen extensivering, zoals permanent grasland. Andere werken extensivering tegen, zoals een $\mathrm{KPI}$ voor $\mathrm{CO}_{2}$-eq./kg product. Per kg product is het immers voor intensieve bedrijven gemakkelijker om laag te scoren op broeikasgasemissie vanwege de hogere productie. De keten kan gestimuleerd worden om bij te dragen aan extensivering van de landbouw door een vraag en betalingsbereidheid vanuit consumenten, onderzoek naar en regelgeving voor certificeringsschema's, en de publieke opinie die vraagt om extensivering.

De keten kan dus vraag creëren naar producten van extensieve bedrijven (Runhaar et al., 2017). Overheden kunnen eveneens een vraag creëren door middel van subsidieregelingen voor braaklegging, agrarisch natuurbeheer, biologische landbouw en andere extensieve landbouwmethoden. Voor het verdienmodel van extensieve bedrijven is vaak het goedkoop of niet pachten van natuurgrond belangrijk, evenals een beheer- of loonwerkvergoeding voor de beheerskosten van de grond. Boeren hebben vaak een voorkeur voor betaling via het product boven subsidies (Westerink et al., 2018b). Tot nu toe dragen de programma's van de keten echter nog maar beperkt bij aan het verdienmodel van extensieve bedrijven, omdat ze met name de grote groep bedrijven bedienen ('het peloton').

Via regelgeving communiceren overheden over normen van een 'goede landbouwpraktijk'. De duurzaamheidsprogramma's van de ketenpartijen en ook certificeringsprogramma's zoals 'biologisch' communiceren met hun KPI's en regels eveneens normen voor 'duurzaam'. Deze normen zijn bovenwettelijk: ze gaan verder dan de wettelijke regels.

Wettelijke regelgeving kan bijdragen aan extensivering, zoals in het geval van de Fosfaatwet die leidde tot een krimp van de veestapel. Regelgeving zoals bescherming van een bepaald gebied kan de drempel verlagen om mee te doen met een subsidieregeling, om er zo toch maar het beste van te maken (Van Herzele et al., 2013). Regelgeving kan echter ook extensivering tegenwerken. Doordat de huidige regelgeving niet stuurt op extensivering, hebben extensieve bedrijven door hun hogere kostprijs een concurrentienadeel: met strengere regelgeving bijvoorbeeld ten aanzien van bemesting zouden de prijzen per $\mathrm{kg}$ product met een goed functionerende markt vanzelf stijgen. Vanwege staatssteunregels zijn publieke vergoedingen voor extensieve bedrijven niet zonder meer mogelijk (Buizer et al., 2016).

Tot slot kunnen kennisinstellingen, zoals decennialang is bijgedragen aan intensivering, nu bijdragen aan het voorstelbaar en haalbaar maken van extensieve landbouw, met name door het ondersteunen van experimenten met participatief onderzoek en door het beschikbaar maken van kennis voor de praktijk.

\subsubsection{Effectieve sturing richt zich op alle drie en houdt rekening met verschillen}

Effectieve sturing adresseert het willen, het kunnen en de steun van de omgeving (Mills et al., 2016, Runhaar et al., 2017). Volgens Mills et al. is het belangrijk om zicht te krijgen op de factoren die meewerken aan de beoogde gedragsverandering en de factoren die nog niet op groen staan. Extra sturing zou zich op die laatste moeten richten. Als boeren bijvoorbeeld wel willen en er is steun van de omgeving maar ze kunnen niet veranderen, kan de interventie zich richten op het kunnen. Als boeren willen en kunnen, maar er is te weinig steun uit de omgeving, dan kan de interventie worden gericht op 
de omgeving van de boer. Uiteindelijk gaat het om een totaalpakket dat gedragsverandering wenselijk, mogelijk en duurzaam maakt.

Een complicerende factor is dat 'de' boer niet bestaat. Uiteraard zijn er verschillende sectoren en bodemtypen, maar zelfs tussen twee melkveehouderijen met 100 koeien op veen kunnen grote verschillen bestaan. Voor keuzes ten aanzien van extensivering kunnen onder meer de persoonlijke interesse van de boer en zijn of haar karakter een grote rol spelen. Een boer die vooral bezig is met zijn koeien zal vatbaar zijn voor andere argumenten dan een boer die een focus heeft bij bodembeheer of iemand die zijn trots haalt uit een hoge productie (Van der Ploeg et al., 2009). Waar de ene boer risico's zo veel mogelijk mijdt, zal de ander gemakkelijker een avontuur aangaan (Dessart et al., 2019). Van Herzele et al. (2013) lieten zien dat boeren in verschillende omstandigheden andere redenen hadden om wel of niet mee te doen met een regeling voor agrarisch natuurbeheer. Effectieve sturing zal dus rekening moeten houden met diversiteit in omstandigheden, bedrijfsstijlen en karakters.

\subsection{Handelingsperspectieven: instrumenten die bijdragen aan keuzes voor extensivering}

In deze studie definiëren wij handelingsperspectieven voor beleid als volgt: (combinaties van) beleidsinstrumenten die bijdragen aan de door het beleid gewenste keuzes van de doelgroep van het beleid. In ons geval gaat het dus om beleidsinstrumenten die eraan bijdragen dat boeren willen en kunnen extensiveren en dat daarvoor voldoende steun is vanuit hun omgeving. 
Tabel 1 geeft een overzicht van de gevonden handelingsperspectieven voor de overheid voor het stimuleren van extensivering van landbouwbedrijven. In de volgende paragrafen lichten we deze toe.

Tabel 1 In de literatuur gevonden handelingsperspectieven voor de overheid voor het stimuleren van extensivering van de landbouw, geordend naar communicatieve, financieel-economische en juridische instrumenten en of ze bijdragen aan het willen of het kunnen extensiveren van de boer, of de benodigde steun van de omgeving daarvoor.

\begin{tabular}{|c|c|c|c|}
\hline & Communicatief & Financieel-economisch & Juridisch \\
\hline Willen & $\begin{array}{l}\text { - Bespreekbaar maken wat een 'goede } \\
\text { boer' zijn inhoudt } \\
\text { - Zichtbaar maken van natuurinclusief } \\
\text { (extensief) vakmanschap } \\
\text { - Beleid dat aansluit op intrinsieke } \\
\text { waarden } \\
\text { - Meerjarige monitoring waarin de } \\
\text { boer een actieve rol inneemt } \\
\text { - Bestrijding van drempelvrees met } \\
\text { goede voorlichting en kwalitatief } \\
\text { onderzoek } \\
\text { - Het niet langer framen van } \\
\text { Nederland als landbouwexporteur } \\
\text { - Het framen van biodiversiteit als } \\
\text { productiedoel } \\
\text { - Duurzaam als standaardoptie } \\
\text { - Onderzoek naar relatie extensivering } \\
\text { en bedrijfsovername binnen de } \\
\text { familie } \\
\text { - Extensieve landbouw in het agrarisch } \\
\text { onderwijs } \\
\text { - Ondetermijnmaatregelen voor } \\
\text { van duurzame maatregelen }\end{array}$ & $\begin{array}{l}\text { - Gericht inzetten van financiële } \\
\text { middelen om niet-gemotiveerde } \\
\text { boeren over de streep te trekken } \\
\text { - Continuïteit van betalingen }\end{array}$ & $\begin{array}{l}\text { - Eenvoudige procedures en } \\
\text { administratie } \\
\text { - Demotiverende regels aanpassen }\end{array}$ \\
\hline Kunnen & $\begin{array}{l}\text { - Ruimte en tijd voor boeren om } \\
\text { verschillende paden te kunnen } \\
\text { aftasten } \\
\text { - Concepten die een extensieve } \\
\text { bedrijfsvoering voorstelbaar maken } \\
\text { - Wetenschappelijke kennis begrijpelijk } \\
\text { maken } \\
\text { - Lerende netwerken en } \\
\text { praktijknetwerken } \\
\text { - Kennisoverdracht in ieders leerstijl } \\
\text { - Ondersteunen van de ontwikkeling } \\
\text { van vaardigheden } \\
\text { - Informatie over maatregelen, } \\
\text { voorbeeldbedrijven, } \\
\text { saldoberekeningen en mogelijkheden } \\
\text { voor financiering } \\
\text { - Maatregelvoorschriften voor niet- } \\
\text { kerende grondbewerking op maat } \\
\text { - Steun voor de ontwikkeling van } \\
\text { - } \text { businessplannen } \\
\text { Bturen op concrete doelen via KPI's } \\
\text { juridisch loket }\end{array}$ & $\begin{array}{l}\text { - Het diversifiëren van de eerste } \\
\text { pijler van de GLB } \\
\text { - Steun voor de ontwikkeling van } \\
\text { ondernemingsvaardigheden } \\
\text { - Vergoedingen voor gemaakte } \\
\text { kosten en gederfde inkomsten } \\
\text { - Stengere milieu- en } \\
\text { klimaatheffingen } \\
\text { - Het krimpen van de veestapel } \\
\text { - Groene grondbank } \\
\text { - Transitiefonds voor extensivering } \\
\text { - Sturen met pacht } \\
\text { - Stimuleren van eigendom van } \\
\text { natuurgrond } \\
\text { - Toeristenbelasting ten goede van } \\
\text { extensivering }\end{array}$ & $\begin{array}{l}\text { - Vergunningen voor experimenten } \\
\text { - Meer flexibiliteit in } \\
\text { - } \text { beheervoorschriften } \\
\text { pachtvospecifiek maatwerk in } \\
\text { - Aanpassing pachtwet } \\
\text { - Ruimte in regelgeving } \\
\text { - Beperken van de } \\
\text { milieugebruikersruimte } \\
\text { - Minder eiwitrijk krachtvoer } \\
\text { - Staleisen voor het verlagen van } \\
\text { de toegestane methaanemissie in } \\
\text { de melkveehouderij } \\
\text { - Eisen aan grondgebondenheid in } \\
\text { melkveehouderij } \\
\text { - Aanscherpen fosfaatrechten } \\
\text { - Wettelijk instrumentarium voor } \\
\text { handhaving van } \\
\text { ammoniakemissiegrens } \\
\text { - Verbod } \\
\text { gewasbeschermingsmiddelen } \\
\text { N- en P-gebruiksnormen voor } \\
\text { akkerbouw }\end{array}$ \\
\hline
\end{tabular}




\begin{tabular}{|c|c|c|c|}
\hline & Communicatief & Financieel-economisch & Juridisch \\
\hline $\begin{array}{l}\text { Steun van } \\
\text { de } \\
\text { omgeving }\end{array}$ & 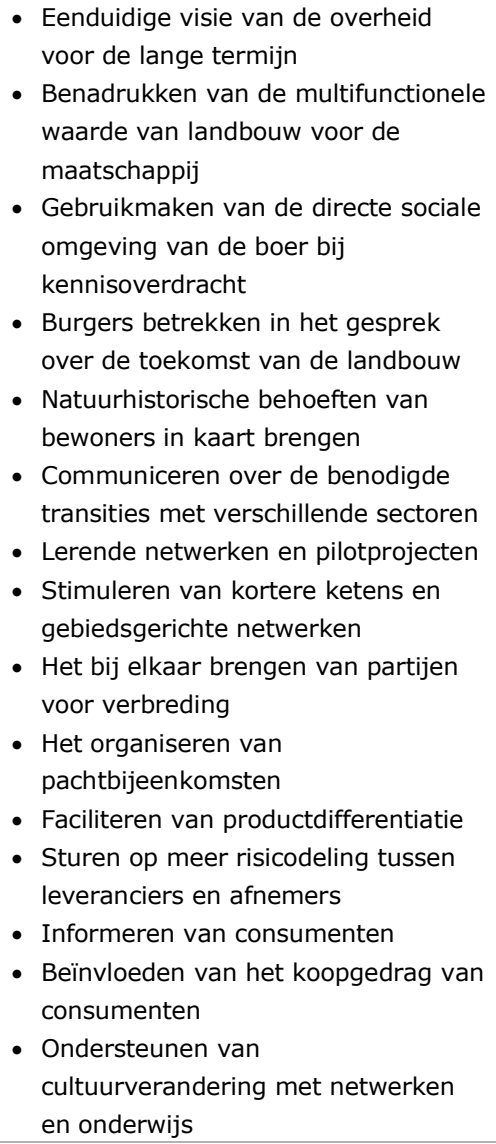 & $\begin{array}{l}\text { - Gestapelde beloning via KPI- } \\
\text { - Systematiek } \\
\text { investeringssubsidies } \\
\text { - Investeringsruimte voor nieuwe } \\
\text { boeren } \\
\text { - Opleiden en aanstellen van } \\
\text { onafhankelijke (erf)coaches } \\
\text { - Professionele agrarische } \\
\text { collectieven \& coöperatieven } \\
\text { - Rentekorting bij de bankensector } \\
\text { voor duurzame investeringen } \\
\text { - De maatschappelijke kosten van } \\
\text { milieuschade meenemen in de } \\
\text { productkosten } \\
\text { - Abonnementen als verdienmodel }\end{array}$ & $\begin{array}{l}\text { - Europese afspraken vertalen naar } \\
\text { in een Nationaal Akkoord } \\
\text { - Ketenafspraken voor een } \\
\text { circulaire economie } \\
\text { - Certificering } \\
\text { - Marktregulering van stikstof- en } \\
\text { fosfaatrechten } \\
\text { - Meer weidegang voor } \\
\text { melkveehouderij }\end{array}$ \\
\hline
\end{tabular}

\subsection{Communicatieve instrumenten}

\subsubsection{Instrumenten die bijdragen aan willen}

\section{Bespreekbaar maken wat een 'goede boer' zijn inhoudt}

Het bespreekbaar maken van wat een 'goede extensieve boer' is in bijeenkomsten met boeren draagt bij aan de zelfidentiteit van extensieve boeren (Westerink et al., 2019b, 2020b; Runhaar, 2020). Wanneer duidelijk wordt dat een extensieve boer wordt gezien als goede boer, en dit uitgedragen wordt als gedeelde norm in de groep, wordt het bereiken van een extensieve bedrijfsvoering een doel op zichzelf, iets waar een boer trots op kan zijn. Het benoemen van zichtbare symbolen en indicatoren voor 'goed extensief' kan gezonde rivaliteit tussen boeren bevorderen; een dergelijke uitdaging werkt motiverend (Westerink et al., 2018b). Wanneer extensief als gedeelde norm wordt geaccepteerd verschuift bijvoorbeeld ook het waardeoordeel van efficiëntie. 'Goed vakmanschap' betekent voortaan duurzaam vakmanschap en daarmee berust efficiëntie niet langer enkel op een hoog rendement, maar op lange termijn rendement.

\section{Zichtbaar maken van natuurinclusief (extensief) vakmanschap}

Boeren hebben de behoefte om aan zichzelf en aan collega's te laten zien dat ze een goede boer zijn. Dit doen ze vooral in het landschap, maar er zijn meer mogelijkheden, waaronder het publiceren van monitoringsresultaten. Ook het framen van biodiversiteit in termen van productie of prestatie helpt mee. Door natuur als teelt met productiedoelen te benaderen, sluit communicatie beter aan bij de denkwereld van veel boeren, daarmee worden zij uitgedaagd in hun vakmanschap (Westerink et al., 2019b). Deelname aan agrarisch natuurbeheer (ANLb) draagt zodoende bij aan het sociale imago van de boer (Polman \& Dijkshoorn, 2019; Runhaar, 2020). Als boeren extensieve praktijken eenmaal weten te herkennen, is het raadzaam boeren hun praktijken met elkaar te laten vergelijken. Dit wakkert vaak de motivatie aan om het beter te doen dan de ander (Dessart et al., 2019; Westerink et al., 2018b). 
In gebieden waar al meerdere boeren een extensieve bedrijfsvoering hebben of andere duurzame praktijken verrichten, willen andere boeren zich daar vaker ook naar schikken, omdat zij het idee hebben dat er sprake is van een collectieve verandering. In gebieden waar dergelijke praktijken echter nooit of nauwelijks te vinden zijn, kan het uitlichten van extensieve bedrijven echter een averechts effect hebben (extensieve boeren kunnen bijvoorbeeld zo ver buiten de sociale norm vallen dat zij worden buitengesloten). In dit soort gebieden (met veel intensieve landbouw) werken financiële prikkels mogelijk beter (Dessart et al., 2019).

\section{Beleid dat aansluit op intrinsieke waarden}

Beleid dat intrinsieke (familie)waarden onderschrijft, heeft een grotere kans om stand te houden dan beleid dat gefundeerd is op enkel financiële prikkels (Dessart et al., 2019). Boeren hechten bijvoorbeeld veel waarde aan de instandhouding van het agrarisch landschap (Duffhues et al., 2009). Door aan te sluiten bij elementen die vanuit het perspectief van de boer behoren tot dit landschap en die ook voor de volgende generaties moeten worden beschermd, wordt beleid sneller geaccepteerd. Bij het stimuleren van landbouwpraktijken, zoals verlaat of gefaseerd maaien, helpt het bijvoorbeeld om daarbij te verwijzen naar de relatie tussen boeren en weidevogels. De boer wordt hierbij gestimuleerd dergelijke praktijken te internaliseren als 'goede praktijken' (Runhaar et al., 2020).

\section{Meerjarige monitoring waarin de boer een actieve rol inneemt}

Meerjarige monitoring is een praktisch overtuigingsmiddel dat inzicht geeft in het resultaat van de inzet van boeren (De Jong, 2020; Erisman \& Verhoeven, 2020). Resultaten zien motiveert en geeft vertrouwen om door te gaan: als bijvoorbeeld de resultaten van agrarisch natuurbeheer zichtbaar worden, of herstelmaatregelen van de bodemkwaliteit ook kwalitatief betere producten gaan opleveren (Polman \& Dijkhoorn, 2019; Runhaar et al., 2018; Vrolijk et al., 2020). Daarvoor is het dus belangrijk dat boeren hun eigen resultaten kunnen herkennen (Westerink et al., 2019b). De nadruk ligt specifiek op meerjarig, omdat de omschakeling van bedrijfssystemen simpelweg veel tijd en veel doorzettingsvermogen vraagt. Boeren zien zichzelf hierin als actieve informatieverzamelaars (De Lauwere \& Van der Burg, 2019). ${ }^{3}$ Daarom moeten zij in staat worden gesteld een centrale positie in te nemen bij de reflectie, bijsturing en coördinatie van (biodiversiteits)monitoring (Bremmer et al., 2020; Paul, 2021).

\section{Bestrijding van drempelvrees met goede voorlichting en kwalitatief onderzoek}

Onzekerheid in de sector rondom gewasbescherming, kunstmest en medicijngebruik houdt tot op heden extensivering tegen, terwijl daar juist flink op bespaard kan worden (Bremmer et al., 2020; De Lauwere \& Van der Burg 2019; Hoes et al., 2020). Omdat boeren onbekend zijn met alternatieve methoden en er nog geen ervaring mee hebben opgedaan, durven ze hun vertrouwde methodes nog niet los te laten en schatten ze de risico's daarvan hoog in. Deze zorgen kunnen alleen weggenomen worden als een alternatief zich in hun ogen echt heeft bewezen. Voorlichting op basis van veldonderzoek is daarbij behulpzaam, waarbij de methoden van voorlichting versterkt kunnen worden met inzichten uit kwalitatief onderzoek naar de sociale leefwereld van boeren en hun perceptie ten opzichte van de overheid (De Koeijer et al., 2018; Runhaar et al., 2018).

\section{Het niet langer framen van Nederland als landbouwexporteur}

Een deel van de landbouwsector haalt zijn trots uit 'het voeden van de wereld', maar tegelijkertijd houdt dit discours een ecologisch onhoudbaar systeem in stand (Van Lieshout, 2014). Het als Nederlandse overheid uitdragen van een vorm van trots op de agro-exportpositie legitimeert dit discours. Voor extensivering zou het bevorderlijker zijn om frames te gebruiken die de Nederlandse pionierspositie in duurzame innovatie bevestigen (Grin et al., 2015; Fresco \& Poppe, 2016; Polman \& Dijkshoorn, 2019; Hoes et al., 2020). Het benadrukken van extensieve landbouw om zijn beperkte milieu-impact werkt bijvoorbeeld stimulerend (Hoes et al., 2020).

\section{Het framen van biodiversiteit als productiedoel}

Een ander nuttig frame is die van biodiversiteit als productiedoel, met optimalisatie als uitgangspunt in plaats van maximalisatie (Louis Bolk Instituut, 2016; Schoonhoven \& Runhaar, 2018; Silvis et al., 2021; Westerink et al., 2019bc). Productie sluit aan bij de vaardigheden van boeren, waarmee het voor veel boeren verenigbaar wordt met hun zelfidentiteit. Extensiveren biedt een mogelijkheid om naar dit

\footnotetext{
3 BIMAG is een succesvol voorbeeld: https://www.vlinderstichting.nl/bimag/
} 
productiedoel toe te werken. Vergelijkbaar is het denken in ecosysteemdiensten, waarbij boeren niet alleen voedsel leveren, maar ook onder meer een goede waterkwaliteit en een mooi landschap.

\section{Duurzaam als standaard optie}

Met simpele aanpassingen in de communicatie kan de duurzame optie vaak aantrekkelijker worden gemaakt. Door de duurzame optie bovenaan te plaatsen in formulieren waarmee boeren duurzaamheidssubsidies kunnen aanvragen, of daarvan de standaardoptie te maken, wordt meedoen aantrekkelijk en laagdrempelig gemaakt (Westerink et al., 2018b). Daarnaast is transparantie in het selectieproces van subsidiegerechtigden belangrijk.

\section{Onderzoek naar relatie extensivering en bedrijfsovername (binnen de familie)}

Familiewaarden staan hoog in het vaandel bij boeren (Duffhues et al., 2009; Famar-Bowers \& Lane, 2009; Smits \& Bos, 2016; Westerink et al., 2018). Het liefst zien zij dan ook dat hun bedrijf binnen de familie wordt overgenomen, maar steeds meer jongeren zien hiervan af. ${ }^{4}$ Naast het vinden van een opvolger hangt het bestaansrecht van een boerenbedrijf volgens financiële experts op lange termijn ook deels af van maatschappelijke acceptatie (Van Zessen, 2018). Aspecten als dierenwelzijn en duurzaamheid zijn voor burgers belangrijke factoren die een rol spelen in hun perceptie en acceptatie ten aanzien van de landbouwsector (Sijtseman et al., 2009). Extensieve bedrijven scoren over het algemeen beter op deze aspecten dan intensieve bedrijven. De Koeijer et al. (2016) achten het mogelijk dat het vooruitzicht op betere maatschappelijke acceptatie een besluit tot bedrijfsovername aantrekkelijker kan maken. Deze stelling moet echter nog onderzocht worden.

\section{Extensieve landbouw in het agrarisch onderwijs}

Het agrarisch onderwijs is een belangrijke plek voor opleiding en het ontwikkelen van een cultuur onder jonge boeren die extensieve landbouw accepteert als goede landbouw. Daarbij moet er ook aandacht besteed worden aan strategieën voor extensivering bij bedrijfsovername (Runhaar et al., 2020). Er is namelijk een grote kans dat er sprake is van intergenerationele verschillen waarin het idee van een 'goede boer' een andere invulling heeft (Farmar-Bowers \& Lane, 2009; Dessart et al., 2019). Het is dus belangrijk om jonge boeren bij te staan in hun ambitie om aanpassingen te maken op de bedrijfscultuur die misschien traditiegetrouw meer in het verlengde van intensivering lag. Dijkshoorn-Dekker \& Kortstee (2020) pleiten voor het actualiseren van het curriculum op grond van de veronderstelling dat toekomstige ondernemers meer proactief aan de slag gaan met biodiversiteit binnen hun bedrijfsvoering. De Taskforce Verdienvermogen Kringlooplandbouw (2019) stelt dat ondernemerschap, kringlooplandbouw én levenslang leren een prominent onderdeel moeten zijn. Beide aanbevelingen kunnen extensivering ondersteunen.

\section{Kortetermijnmaatregelen voor specifieke groepen}

Door maatregelen voor de korte termijn als eerste te richten op groepen die op basis van hun persoonlijkheid, inschatting van welwillendheid, risicotolerantie en milieubetrokkenheid eerder bereid zijn om mee te werken, wordt de kans op directe impact vergroot (Dessart et al., 2019). Er gaat anders veel energie verloren aan het betrekken van onwelwillende partijen. De kans dat zij zich later aansluiten, na het zien van succesvolle voorbeelden om hen heen, is groter. Dit 'crowding out'-effect is naar schatting het relevantst met betrekking tot maatregelen waar betalingen niet, of slechts bescheiden van toepassing zijn. Dat komt omdat boeren die willen meewerken aan dergelijke maatregelen intrinsiek gemotiveerd zijn. Vooral jongere boeren lijken meer zorg te dragen over het milieu, omdat zij nog een lange weg te gaan hebben (Dessart et al., 2019; De Koeijer et al., 2016; 2018). Daardoor zijn zij vaker bereid om hogere risico's te nemen en af te wijken van gangbare zaken. Ook lijken zij vaker bereid om 'meer' te doen ten behoeve van een duurzame bedrijfsvoering. Zogenaamde vrijwillige maatregelen, waar geen financiële compensatie voor beschikbaar is, hebben daarom een betere kans om opgepakt te worden als die specifiek op deze groep gericht zijn. De link met leeftijd is echter niet eenduidig: er zijn ook oudere boeren die er meer voor open staan omdat hun schuldenlast kleiner is, en jongeren die alleen maar op de trekker willen zitten.

\footnotetext{
4 'Gebrek aan jonge boeren is een groot probleem' - Nieuws Bedrijfsopvolging | Boerenbusiness.nl.
} 


\section{Onderzoek naar regionale inpassing van duurzame maatregelen}

De Transition Support System approach (TSS) is een voorbeeld van een benadering die lokaal maatwerk benadrukt (Vrolijk et al., 2020; Dijkshoorn-Dekker et al., 2019). Door de inpassing van maatregelen regionaal te onderzoeken, kan er beter rekening gehouden worden met specifieke bodemsoorten. In de praktijk betekent dit handelingsperspectief een verschuiving van onderzoek ten bate van hoge inputsystemen naar onderzoek naar het versterken van bodem-ecosysteemdiensten (Hoes et al., 2020; Paul, 2021). Bij ondernemers die hun bodem zien als intrinsiek onderdeel van hun bedrijf zouden de voordelen van duurzaam bodembeheer voor de bodemkwaliteit en het bodemleven meer benadrukt kunnen worden (De Lauwere \& Van der Burg 2019). Intensieve monitoring draagt bij aan het zichtbaar maken van de effecten van extensivering op de bodem en de daaraan verbonden opgaves zoals bodemdaling veengronden, klimaatadaptatie en biodiversiteitsherstel. Reflexieve monitoring is erop gericht om te kunnen bijsturen waar nodig (Bremmer et al., 2020).

\subsubsection{Instrumenten die bijdragen aan kunnen}

\section{Ruimte en tijd voor boeren om verschillende paden te kunnen aftasten}

Boeren moeten voldoende ruimte ervaren om verschillende paden richting extensiveren te kunnen aftasten om een voor hen geschikte inpassing te maken in hun bedrijfsvoering (Smits \& Bos, 2016; Taskforce Verdienvermogen Kringlooplandbouw, 2019). Deze ruimte kan bijvoorbeeld worden gecreëerd door het benoemen van inzet in plaats van het benadrukken van directe resultaten. Alleen door middel van een opeenstapeling van verschillende, succesvolle alternatieven kan een eventuele landbouwtransitie in gang worden gezet (Bremmer et al., 2020; Grin et al., 2015; Hoes, 2018; Termeer, 2019). Begin daarom met kleinschalig opbouwen. Ervaring met een kleine stap maakt een volgende stap gemakkelijker. Onderhoud van houtwallen en bloemenstroken is bijvoorbeeld relatief laagdrempelig en brengt al gauw resultaat (Melman et al., 2013). Met kleine stappen zijn mijlpalen eerder te behalen en kunnen hordes sneller worden overwonnen. Dat geeft de boer meer voldoening. Overheden kunnen helpen met het opbouwen van ervaring door bijvoorbeeld pilots te stimuleren.

\section{Concepten die een extensieve bedrijfsvoering voorstelbaar maken}

Extensieve bedrijfsconcepten zoals Boeren voor Natuur kunnen boeren helpen om zich een beeld te vormen van wat extensieve bedrijfsvoering voor hen zou kunnen betekenen (Westerink et al., $2018 \mathrm{a}$ ). Een andere optie is om extensivering te integreren in een breder bedrijfsconcept, met activiteiten waaraan natuurinclusiviteit waarde toevoegt, zoals zorg, educatie, recreatie etc. Dergelijke initiatieven zorgen bij elkaar opgeteld voor opschaling door middel van strategisch niche management (Grin et al., 2015).

\section{Wetenschappelijke kennis begrijpelijk maken}

Onderzoeksinstellingen en ketenpartijen ontwikkelen innovaties in nauwe afstemming met de primaire landbouw, zoals nieuwe rassen, alternatieve teeltmethodes en nieuwe toepassingen voor reststromen. Deze dragen bij aan lagere productiekosten voor kringloopboeren en extensivering (Taskforce Verdienvermogen Kringlooplandbouw, 2019). Ook kwalitatieve onderzoeken dragen bij aan kennis over de zienswijze en motivatie van boeren die aanknopingspunten geven voor mogelijke extensivering (De Koeijer et al., 2016). Publicaties hierover zijn echter vaak te wetenschappelijk. Het is daarom belangrijk om wetenschappelijke kennis praktisch te 'vertalen' voor erfbetreders en ondernemers, zodat deze kennis ook daadwerkelijk 'landt' op het boerenerf. Dit kan mogelijk gemaakt worden door het inschakelen van personen of partijen die een goede aansluiting hebben met de boerenbedrijven en die de taal spreken (Dijkshoorn-Dekker \& Kortstee, 2020).

\section{Lerende netwerken en praktijknetwerken}

Het faciliteren van lerende netwerken en praktijknetwerken is een succesvolle manier om kennisoverdracht en samenwerking te realiseren en ook te laten groeien (Polman \& Dijkshoorn, 2019; Runhaar, 2020; Schrijver et al., 2008; Schrijver \& Vijn, 2018; Westerink et al., 2018b; 2020ab). Sommige boeren hebben nauwelijks contact of informatiebronnen buiten hun eigen erf (DijkshoornDekker \& Kortstee, 2020). Zeker voor deze groep dragen (digitale) leernetwerken bij om toch zicht te krijgen op verschillende perspectieven. Door ook terreinbeherende organisaties en natuurvrijwilligers te betrekken, worden bovendien het netwerk en het (politiek) draagvlak van de boer verbreed (Westerink et al., 2018; 2020). Veel boeren hebben behoefte om in de praktijk te beleven wat bepaalde 
maatregelen kunnen opleveren. Hiervoor zijn het opzetten van praktijknetwerken en het aanwijzen van proeflocaties een goede optie (Dijkshoorn-Dekker \& Kortstee, 2020). Voorbeelden zijn het

praktijknetwerk van de 'Experimenten Natuurinclusieve Landbouw' van Staatsbosbeheer en die van de Stichting Weidegang (Runhaar et al., 2020). Overheden kunnen boeren actief wijzen op bestaande praktijknetwerken en nieuwe faciliteren.

\section{Kennisoverdracht in ieders leerstijl}

Niet elke boer heeft dezelfde leerstijl. Voor boeren die actief erop uitgaan, passen bijvoorbeeld praktijknetwerken. Voor het grote deel dat minder actief naar buiten beweegt, zullen erfbetreders of proeflocaties een belangrijke bron van inspiratie zijn (Dijkshoorn-Dekker \& Kortstee, 2020). Overheden kunnen helpen bij het zoeken naar een passende leerstijl door informatie te verstrekken over proeflocaties per regio of gebied, of door te verwijzen naar specifieke boeren die net een stap verder zijn dan het peloton (Dijkshoorn-Dekker \& Kortstee, 2020).

\section{Ondersteunen van de ontwikkeling van vaardigheden}

Extensieve bedrijfsvoering vraagt deels om andere vaardigheden dan intensieve bedrijfsvoering. Voor stapsgewijze extensivering via stroken en akkerranden is bijvoorbeeld precisiewerk nodig. Dit vergt extra (technische) vaardigheden, zoals gebruik van gps bij het maaien (Melman et al., 2013). Overheden kunnen de opbouw van vaardigheden ondersteunen door voorlichting te geven aan sleutelfiguren die deze kennis kunnen doorgeven via leer- en praktijknetwerken.

\section{Informatie over maatregelen, voorbeeldbedrijven, saldoberekeningen en mogelijkheden voor financiering \\ Boeren halen nieuwe kennis vaak uit excursies en vakbladen (Westerink et al., 2018b). Overheden kunnen ervoor zorgen dat informatie over maatregelen, voorbeeldbedrijven, saldoberekeningen en mogelijkheden voor financiering direct bij deze veelgebruikte bronnen van informatie terechtkomen. Bijvoorbeeld door vakbladen en sleutelfiguren te wijzen op onderzoek dat vanuit het ministerie is gefinancierd.}

\section{Maatregelvoorschriften voor niet kerende grondbewerking op maat}

Niet-kerende grondbewerking (NKG) is een maatregel op bedrijfsniveau met veel voordelen voor bodemkwaliteit, waterberging en biodiversiteit. NKG kan bovendien leiden tot hogere saldo's vanwege verbeterde bodemstructuur (Mulder \& Ringelberg in Polman en Dijkshoorn-Dekker (2019); DijkshoornDekker et al., 2020; Erisman et al., 2017). Overheden kunnen boeren helpen om over te schakelen naar NKG met onderzoek en advies op maat.

\section{Steun voor de ontwikkeling van businessplannen}

Een businessplan kan boeren helpen om vertrouwen te krijgen in extensivering als economisch haalbare weg (De Jong, 2020a). Overheden kunnen de ontwikkeling van businessplannen ondersteunen. Om de mogelijkheden in kaart te brengen met boeren kan gebruik worden gemaakt van het CANVASbusinessmodel (Grin et al., 2015; Polman \& Dijkshoorn, 2019; Visser et al., 2015). Als aanvulling op het model kunnen ook de kosten en baten van eventuele certificering meegenomen worden (De Koeijer et al., 2018).

\section{Sturen op concrete doelen via KPI's}

Overheden kunnen concrete doelen stellen zodat duidelijk is wat agrarische ondernemers moeten bereiken. Doelen fungeren als stip op de horizon in plaats van regels of voorschriften die vertellen wat de boer moet doen. Een uitdaging voor deze vorm van overheidssturing is het meetbaar maken van de resultaten op bedrijfsniveau en hoe bedrijfsresultaten te vertalen naar regionaal en nationaal niveau.

Een manier om resultaten te meten op bedrijfsniveau en te vertalen naar regionaal en nationaal niveau is via kritische prestatie-indicatoren (KPI's). KPI's zijn integrale resultaatgerichte indicatoren van het landbouwsysteem (Erisman en Verhoeven, 2020). De KPI's zijn vertaald vanuit verschillende maatschappelijke doelen/opgaven, zoals het verhogen van biodiversiteit en het verlagen van de impact op het milieu etc. naar prestatie op bedrijfsniveau. Op deze wijze kan de overheid sturen op doelen en niet op maatregelen. 
De KPI-systematiek kan gebruikt worden om boeren financieel te belonen voor hun inzet in het behalen van maatschappelijke opgaven. Dit kan een systeem worden van gestapelde beloning waarin zowel de keten als overheden de agrarisch ondernemer financieel belonen. In Nederland zijn er verschillende initiatieven gestart met deze systematiek, zoals de Biodiversiteitsmonitor Melkveehouderij en biodiversiteitsmonitor Akkerbouw (BMM en BMA).

\section{Betere inrichting financieel en juridisch loket}

Boeren willen weten waar ze staan, waar ze aan toe zijn en wat ze kunnen verwachten, speciaal op het gebied van beleid en financiën (Hoes et al., 2020). Een overheid kan hierin tegemoetkomen door te verwijzen naar een loket voor stimuleringsregelingen (subsidies) en kennisvouchers voor financiële stimulansen (Dijkshoorn-Dekker \& Kortstee, 2020). Het loket Agrarisch Ondernemen (RVO) is in principe hiervoor ingericht, maar mist nog een duidelijke routeaanduiding die boeren kunnen volgen om te extensiveren.

\subsubsection{Instrumenten die bijdragen aan steun van de omgeving}

\section{Eenduidige visie van de overheid voor de lange termijn}

Overheidsvisies over de toekomst van de landbouw zijn in het verleden vaak van koers veranderd (Van Lieshout, 2014). Veel boeren zijn wantrouwend om stappen te ondernemen, omdat ze bang zijn telkens weer met een ander dossier geconfronteerd te zullen worden (Runhaar et al., 2020). Een eenduidige, langetermijnvisie, bijvoorbeeld kringlooplandbouw, biedt meerdere invalshoeken richting hetzelfde doeleinde. Deze invalshoeken kunnen eventueel nog in kabinetstermijnen veranderen, maar het einddoel kan beter hetzelfde blijven. Een eenduidige visie van overheden biedt zowel boeren als hun omgeving duidelijkheid over waar de landbouw uiteindelijk heengaat, zodat zij daarop kunnen anticiperen en zich erbij kunnen aansluiten. Bij een eenduidige visie hoort ook een gericht afbouwbeleid voor praktijken die niet meer aansluiten op de nieuwe visie. In het geval van extensivering betekent dit een gericht afbouwbeleid voor intensieve landbouw. Veel boeren hebben bijvoorbeeld de gewoonte om in te grijpen met chemische middelen bij een (dreigende) aantasting van hun gewas (Bremmer et al., 2020). Deze gewoonte is het resultaat van een systematiek met schadedrempels die hun vaak is aangeleerd door commerciële erfbetreders. Als in de overheidsvisie resoluut staat dat dit in de toekomst geen optie meer is, wordt het loslaten van deze en vergelijkbare gewoontes makkelijker.

\section{Benadrukken van de multifunctionele waarde van landbouw voor de maatschappij}

Extensieve boeren leveren meer dan alleen voedsel. Door het benadrukken van de multifunctionele waarde (bijvoorbeeld aan de hand van ecosysteemdiensten) versterkt de maatschappelijke positie van de boer en stijgt de waardering van het publiek (Korevaar, 2006; Hoes et al., 2020; Visser et al., 2015).

\section{Gebruikmaken van de directe sociale omgeving van de boer bij kennisoverdracht}

Advies wordt het best ter harte genomen als het van verwante personen komt zoals vakgenoten, familie of geestverwanten (De Lauwere \& Van der Burg, 2019; Dessart et al., 2019; Dijkshoorn-Dekker \& Kortstee, 2020; Duffhues et al., 2009; Farmar-Bowers \& Lane, 2009; Runhaar, 2020; Westerink et al., 2019b). Voor overheden is het daarom extra belangrijk om te weten wie de belangrijkste 'influencers' zijn van de boer en wat voor hen belangrijk is, om vanuit die zienswijze en beleveniswereld te kunnen communiceren (De Jong, 2020b).

\section{Burgers betrekken in het gesprek over de toekomst van de landbouw}

Bewuste burgers kunnen een belangrijke rol vervullen in de landbouwtransitie (Taskforce Verdienvermogen Kringlooplandbouw, 2019). In gesprek gaan met burgers over de toekomst van de landbouw en hun aandeel daarin kan het bewustzijn vergroten (Westerink et al., 2018b; Hoes, 2020). Burgers worden zo mogelijk gestimuleerd om duurzamer te consumeren. Het mee laten denken van burgers kan via een gebiedsgerichte aanpak met veel ruimte voor burgerinitiatieven, zoals de G1000 Landbouw (Transitie Coalitie Voedsel 31 maart 2021).

\section{Natuurhistorische behoeften van bewoners in kaart brengen}

Het in kaart brengen van de landschappelijke, natuurhistorische en culturele behoeften van bewoners in en nabij het platteland en het faciliteren van een verbinding met de grondeigenaren kunnen leiden tot een (her)waardering van extensieve landschapselementen, zoals kruidenrijk grasland (Schrijver \& Vijn, 2018). 


\section{Communiceren over de benodigde transities met verschillende sectoren}

Een duurzame landbouwtranstransitie is alleen haalbaar als verschillende sectoren met elkaar samenwerken om te streven naar duurzame kringlopen. Daarbij kunnen overheden helpen door te informeren over de benodigde transities binnen verschillende sectoren en ketenpartijen (Paul, 2021). Samenwerkingsmogelijkheden worden daarmee inzichtelijk en grote opgaves worden erkend. Als een sector wordt uitgesloten, of men denkt dat een sector wordt uitgesloten of ontzien, werkt dat demotiverend voor sectoren die zich wel inzetten.

\section{Lerende netwerken en pilotprojecten}

Lerende netwerken en pilotprojecten dragen niet alleen bij aan het 'kunnen' van boeren, zij dragen ook bij aan een stimulerende omgeving voor boeren, omdat anderen mee leren en kennis en ideeën inbrengen. Lerende netwerken en pilotprojecten zijn zo een belangrijk instrumentarium om verspreiding en verdieping van 'small wins' te bevorderen (Bremmer et al., 2020; Westerink et al., 2018b). Dit doen zij bijvoorbeeld door het organiseren van regionaal/gebiedsgerichte themabijeenkomsten voor ondernemers en andere relevante stakeholders zoals ketenpartijen en door onderzoek. Afhankelijk van de opzet van de bijeenkomst kunnen deze een ingang bieden tot het opzetten van nieuwe (praktijk)netwerken. Succesvolle werkvormen kunnen intervisiebijeenkomsten voor trekkers van netwerken \& interregionale 'never ending tour'-netwerken. Deze tour biedt alle netwerkers een kans om kennis te delen, elkaar te ontmoeten, nieuwe verbindingen te slaan en nieuwe opgaves vast te stellen en kan zowel maandelijks fysiek in het land gerealiseerd worden als ook digitaal op een online (kennis)platform om geleerde lessen van verschillende netwerken toegankelijker en bruikbaarder te maken voor een breder publiek (Dijkshoorn-Dekker \& Kortstee, 2020).

\section{Stimuleren van kortere ketens en gebiedsgerichte netwerken}

Regionale/gebiedsgerichte netwerken bieden goede mogelijkheden voor het bij elkaar brengen van ondernemers en andere partijen (bijvoorbeeld ketenpartijen) om actuele ondernemersgerichte onderwerpen of gezamenlijke doelen met elkaar te bespreken. Dit kan gestimuleerd worden vanuit overheden door bijvoorbeeld het inzetten van stimuleringsregelingen, vouchers voor het inhuren van coaches of experts of het aanstellen van trekkers vanuit de overheid voor het opzetten van netwerken (Dijkshoorn-Dekker \& Kortstee, 2020). Met name kortere ketens dragen bij aan een betere prijs voor de producten van de boer (Westerink et al., 2018; Hoes et al., 2020). Een manier om korte ketens en gebiedsgerichte netweken te versterken, is Community Supported Agriculture (CSA) (Hoes et al., 2020). Burgers kunnen bijvoorbeeld dieren of gewassen 'adopteren' en daarvoor een directe financiële bijdragen leveren. Een andere vorm van CSA is het groeiende nieuwe Herenboeren-model. Hierbij draagt een gemeenschap gezamenlijk zorg voor het eigenaarschap van de boerderij door middel van een eenmalige inleg plus wekelijkse betaling, waarna men samen deelt in vruchtgebruik (Jongeneel, 2020). In dit model wordt vaak het initiatief vanuit de gemeenschap gestart, de boer is in loondienst. Er bestaat echter ook een scenario waarin vanuit de boer het initiatief wordt genomen. Als een boer beschikt over een hoog sociaal kapitaal kan een mogelijke route naar extensivering een (gedeeltelijke) bedrijfsoverdracht naar de gemeenschap zijn. Dit scenario kan bijvoorbeeld aantrekkelijk zijn als er geen duidelijke opvolging is (Polman \& Dijkshoorn, 2019).

\section{Het bij elkaar brengen van partijen voor verbreding}

De verdienmodellen van veel natuurinclusieve en extensieve bedrijven zijn deels gebaseerd op het realiseren van meerwaarde voor het bedrijf. Een manier om dit te doen, is door het bedrijf te verbreden. Vaak werken boeren daarvoor samen met andere partijen zoals provincies, waterschappen of Staatsbosbeheer; bijvoorbeeld in relatie tot (gedeeltelijk) natuurbeheer (Grin et al., 2015; Polman \& Dijkshoorn, 2019). Maar ook de samenwerking met de zorgsector is aan het groeien, wat onder andere te zien is aan het sterk groeiende aantal zorgboerderijen (Hoes, 2018; Vrolijk et al., 2020). Overheden kunnen boeren hierin ondersteunen door het aandragen van voorbeelden en door zelf als actieve samenwerkingspartner op te treden.

\section{Het organiseren van pachtbijeenkomsten}

De relatie tussen pachter en verpachter is van invloed op onderhandelingsmogelijkheden van de boer. Om het vertrouwen tussen beiden te stimuleren, is transparantie essentieel. Meer transparantie kan worden behaald door middel van het faciliteren van pachtbijeenkomsten. Dit zijn bijeenkomsten waarbij pachters en verpachters met elkaar in gesprek gaan om duurzame pachtscenario's uit te denken. Een 
mooi voorbeeld is het Akkoord Samen Werkt Beter in Overijsel waar verschillende partijen afspraken hebben gemaakt om te grondprijs betaalbaar te houden en de ecologie te versterken (Schrijver \& Vijn, 2018; Schrijver et al., 2019).

\section{Faciliteren van productdifferentiatie}

De prijs die boeren ontvangen voor hun producten is een grote drijfveer. Maar een ongereguleerde marktwerking biedt weinig garantie op stabiele productprijzen. Productdifferentiatie kan helpen bij het stabiliseren van productprijzen doordat een product zich kan onderscheiden, bijvoorbeeld omdat het product op duurzame wijze is geproduceerd. Productdifferentiatie draagt als het ware bij aan de exclusiviteit van extensief geproduceerde producten. Productdifferentiatie kan onder andere worden verwezenlijkt als er (prijs)afspraken worden gemaakt tussen producenten en afnemende partijen. Dit kan zowel horizontaal (boeren en tuinders onderling) als verticaal in de keten (ketenpartijen) (Taskforce Verdienvermogen Kringlooplandbouw 2019, p. 39). Voor boeren is het voordelig als productdifferentiatie onderaan begint, dus bij de mensen die de producten daadwerkelijk produceren. Daarna kunnen ketenpartijen (en consumenten) zich bereid tonen om een eerlijke meerprijs te betalen (De Groot Ruiz et al., 2018). Onlangs is het wetsvoorstel 'Wet oneerlijke handelspraktijken landbouwen voedselvoorzieningsketen' aangenomen om de positie van de boer in de keten te versterken. ${ }^{5}$

Een andere manier om bij te dragen aan productdifferentiatie is het introduceren van een keurmerk voor extensief geproduceerde producten (Hoes et al., 2020). Een keurmerk kan op twee manieren worden ingezet: enerzijds om producten met meerwaarde te kunnen vermarkten en daarmee ook een meerprijs af te dwingen bij ketenpartijen, maar anderzijds ook als sociaal herkenningsinstrument. Hierbij is het doel dat een extensieve boer aan zijn omgeving laat zien dat hij op extensieve wijze handelt en daarbij een voorbeeldfunctie wil innemen (Polman \& Dijkshoorn, 2019).

\section{Sturen op meer risicodeling tussen leveranciers en afnemers}

Voor het stimuleren van extensivering is het wenselijk dat langetermijncontracten tussen leveranciers en afnemers waarin afspraken staan over risicodeling de nieuwe norm worden. Dit biedt ondernemers de zekerheid om te investeren. De nieuwe standaardcontracten bevatten fatsoenlijke inkoop- en verkoopvoorwaarden en tijdige betaling voor primaire producenten. Boeren, tuinders en ketenpartijen kunnen deze inkoop- en verkoopvoorwaarden zelf opstellen. Lukt het de sector echter niet om zelf tot afspraken te komen, kunnen overheden optreden. Bijvoorbeeld door te wijzen op doelen die zijn vastgesteld in een (mogelijk) Nationaal Akkoord (blz. 42) (Taskforce Verdienvermogen Kringlooplandbouw, 2019).

\section{Informeren van consumenten}

Het informeren van burgers over gezonde en milieuvriendelijke voeding is van belang om de prijspremie van extensieve producten te rechtvaardigen en draagvlak voor duurzaam voedsel te vergroten (Van Grinsven et al., 2015). De waardering van consumenten en burgers voor de producten, diensten en prestaties die door de boeren worden geleverd en zoals die tot uitdrukking komt in de prijzen en/of vergoedingen die worden betaald, is bovendien een grote drijfveer voor veel boeren (Jongeneel, 2020). Informatie kan worden verstrekt via voorlichtingscampagnes of een mediastrategie over de 'ware kosten van producten', inclusief ecologische voetafdruk (De Groot Ruiz et al., 2018; Dessart, 2019; Jongeneel et al., 2019). Dit kan vanaf jonge leeftijd al door 'voedselonderwijs' (Hoes, 2018). Volwassen consumenten kunnen nog beter worden gewezen op hun rol bij de transitie richting circulaire landbouw. Bijvoorbeeld door het positief benadrukken van de ecologische waarde van een aangepast, duurzaam of extensief voedselpatroon (Taskforce Verdienvermogen Kringlooplandbouw, 2019).

\section{Beinvloeden van het koopgedrag van consumenten}

Het aankoopgedrag van consumenten kan worden gestimuleerd door gezonde en duurzame voeding aan te prijzen met aantrekkelijke verpakkingen/keurmerken (Hoes, 2018) of door hun plaats in het schap (Taskforce Verdienvermogen Kringlooplandbouw, 2019). De afzetketen speelt hier met name een grote rol in (Bremmer et al., 2020), maar overheden kunnen hierover wel het gesprek aan gaan met bijvoorbeeld supermarktketens.

\footnotetext{
5 https://zoek.officielebekendmakingen.nl/stb-2021-178.htm
} 


\section{Ondersteunen van cultuurverandering met netwerken en onderwijs}

Voor de ontwikkeling van natuurinclusieve culturele normen is het nodig dat boeren ervaring op kunnen doen met natuurinclusieve praktijken, zodat ze die ook bij anderen kunnen herkennen. Boeren vinden erkenning van hun vakmanschap bij elkaar en identificeren zich als goede boer door een vergelijking te trekken met anderen. De agrarische collectieven zijn een goed functionerend voorbeeld van een natuurinclusieve subcultuur (Westerink et al., 2019b). Eenzelfde culturele normontwikkeling is belangrijk voor extensieve praktijken. Vanuit het agrarisch onderwijs kan een bijdrage worden geleverd aan de culturele normverandering door extensivering bespreekbaar te maken en in het curriculum op te nemen (Runhaar et al., 2020).

\subsection{Financiële instrumenten}

\subsubsection{Instrumenten die bijdragen aan willen}

\section{Gericht inzetten van financiële middelen om niet-gemotiveerde boeren over de streep te trekken}

Veel extensieve boeren doen ook aan agrarisch natuurbeheer en krijgen daar een vergoeding voor gederfde inkomsten voor, via het subsidiestelsel Agrarisch Natuur- en Landschapsbeheer (ANLb). De studie van Boonstra et al. (2021) neemt waar dat de deelnamebereidheid voor het ANLb is toegenomen. Dit heeft onder andere te maken met de toenemende maatschappelijke druk om te verduurzamen, maar ook doordat gebiedscoördinatoren zichtbare een concrete voorbeelden kunnen voordragen, maar er zijn ook boeren die meedoen vanuit een economisch motief. De studie van Runhaar et al. (2020) laat zien dat boeren die deelnemen aan het ANLb vaak al een intrinsieke motivatie hebben om zich in te zetten voor natuur. Meer financiële prikkels hebben met name invloed op de bereidheid van boeren die deze intrinsieke motivatie nog niet hebben, vaak omdat er in hun omgeving weinig interesse voor is (Dessart et al., 2019). Voor ondernemers die hun bodem vooral instrumenteel zien, dus als middel om geld te verdienen, zouden de financiële voordelen van duurzaam bodembeheer meer benadrukt kunnen worden (De Lauwere \& Van der Burg, 2019).

\section{Continuïteit van betalingen}

Subsidiestelsels in Nederland hebben vaak een relatief korte looptijd en zijn soms alleen toepasbaar op bepaalde kerngebieden. Bovendien zijn de maatregelvoorschriften die aan subsidies zijn verbonden aan verandering onderhevig. Een belemmering is bijvoorbeeld dat het ANLb gericht is op kerngebieden met VHR-soorten, met als gevolg dat je maar in een beperkt deel in Nederland contracten af kunt sluiten als boer. Dat maakt het ANLb minder geschikt voor het sturen op een brede verandering, daar is het nieuwe GLB geschikter voor (Boonstra et al., 2021). Boeren uiten ook weinig vertrouwen over het structurele karakter van het uitbetalen van beheersvergoedingen door overheden (Jongeneel, 2020). Boeren willen niet het ene jaar allerlei maatregelen moeten nemen en pas het volgende jaar daarvoor beloond worden, dit ervaren zij als onprettig en demotiverend (De Lauwere \& Van der Burg, 2019). Beter inzicht in de vooruitzichten rondom de continuïteit van beheersvergoedingen en maatregelen zou daarbij kunnen helpen.

\subsubsection{Instrumenten die bijdragen aan kunnen}

\section{Het diversifiëren van de eerste pijler van de GLB}

Een principe waarmee gezorgd kan worden dat het GLB de transitie naar een meer natuurinclusieve landbouw zal versterken, is dat de financiële prikkels uit het verplichte deel van de eerste pijler niet zullen leiden tot verdere homogenisering en intensivering van het landgebruik zoals in het verleden telkens het geval was. Tot dusver bestaat het GLB uit twee pijlers: de eerste zijn landbouwsubsidies zoals inkomensondersteuning en het markt- en prijsbeleid. De tweede is gericht op plattelandsontwikkeling. Geld voor natuurinclusieve landbouw komt uit de tweede pijler. Het ambitieniveau en het budget van de tweede pijler zijn echter relatief laag in verhouding tot de eerste pijler, wat ertoe leidt dat boeren vooral geprikkeld worden op het gebied van hun productiviteit. Boeren kunnen met minimale inzet voldoen aan de milieu- en klimaateisen die worden gesteld. Deze eisen zijn voornamelijk afgestemd op stikstofreductie en nauwelijks op biodiversiteitswinst op het platteland. 
Maatregelen die sinds 2014 zijn genomen om de eerste pijler te vergroenen, mogen overlappen met maatregelen voor de tweede pijler. Boeren worden zo onvoldoende geprikkeld om grote investeringen te maken op het gebied van biodiversiteitswinst. De Kleijn (2018) stelt daarom dat prikkels uit de eerste pijler meer diversifiëring van agrarische landschappen (waar mogelijk) zouden moeten bevorderen. Ook zouden volgens hem eco-schema's en agro-milieuklimaatmaatregelen complementair kunnen worden gemaakt aan de prestaties waarop gestuurd gaat worden in de initiatieven door ketenpartners (bijvoorbeeld de biodiversiteitsmonitor van Royal Friesland Campina Rabobank en het WNF). Hierdoor krijgen boeren meerdere financiële prikkels tegelijk die aanzetten tot meer natuurinclusief beheer. Jongeneel (2020) doet een praktisch voorstel om hectaretoeslag bijvoorbeeld uit te betalen op basis van karakteristieken van het bedrijf.

\section{Steun voor de ontwikkeling van ondernemingsvaardigheden}

Door snelle verandering in beleid wordt er steeds meer van het ondernemerschap van de boer gevraagd. De verwachting wordt geschetst dat boeren zelf actie ondernemen en naar creatieve oplossingen op zoek gaan. Dat vergt ondernemingsvaardigheden. Overheden kunnen investeren in ondernemingsvaardigheden van boeren zodat deze meer zelfvertrouwen ervaren in het zoeken naar oplossingen en het nemen van maatregelen (Hoes et al., 2020; Vrolijk et al., 2020). Dit kan onder meer door het bekostigen van studiegroepen en trainingen (Hoes et al., 2020). Meer gericht op het toepassen van ondernemingsvaardigheden, kan het boeren helpen als zij worden betrokken bij pilotprojecten. Bij pilotprojecten kan het van toegevoegde waarde zijn om te voorzien in een financieel vangnet voor aanvullende risico's die boeren lopen tijdens de duur van het pilotproject (Bremmer et al., 2020).

\section{Vergoedingen voor gemaakte kosten en gederfde inkomsten}

Extensivering gaat vaak gepaard met lagere opbrengsten, extra kosten en extra tijd/arbeid (Beldman et al., 2019). Sommige kosten zijn tijdelijk, bijvoorbeeld in relatie tot omschakeling en (meerjarige) experimenten. Deze meerkosten kunnen door overheden gecompenseerd worden, zodat een boer meer zekerheid op voldoende inkomsten heeft. Tijdelijke meerkosten zijn bijvoorbeeld de arbeid die gepaard gaat met zwaardere beheersmaatregelen (zoals zelfcompostering) en bodemmaatregelen die leiden tot tijdelijke opbrengstenderving (De Lauwere \& Van der Burg 2019). Voordat tijdelijke meerkosten gecompenseerd kunnen worden, dient een goede inschatting te worden gemaakt van de exacte duur van de vergoeding; dit kan per omschakeling verschillen. Het doel van tijdelijke compensatie is om bodemstructuren en overige ecologische processen te herstellen. Is dat eenmaal gebeurd, dan is het aan de boer zelf om te voorzien in een verdienmodel. Bij zeer extensieve bedrijfsmodellen is een verdienmodel echter niet vanzelfsprekend (Schrijver et al., 2021). De overheid kan dan, vanwege de geleverde ecosysteemdiensten, kiezen voor een langjarige vergoeding à la Boeren voor Natuur (Westerink et al., 2013, 2018a). Boeren voor Natuur betekent netto verschraling op bedrijfsniveau, hogere waterstanden en minimaal $10 \%$ landschapselementen en is daarmee met name geschikt voor zones rond natuurgebieden en in beekdalen. Langjarige afspraken maken het mogelijk voor de boer om zijn of haar bedrijf drastisch te extensiveren en geven tijd voor herstel van landschap, biodiversiteit en waterkwaliteit.

\section{Strengere milieu-en klimaatheffingen}

Een manier om vergoedingen van maatregelen te bekostigen, is volgens de Taskforce Verdienvermogen Kringlooplandbouw (2019) een regulerende heffing op ongeprijsde, nadelige milieu- en klimaateffecten. Deze geldt voor de gehele economie. De opbrengsten zouden daarbij terug kunnen vloeien naar de betreffende sectoren om de gewenste transitie te ondersteunen. Voor landbouw betekent dit onder meer ook heffingen op krachtvoer, kunstmest en verlaagde waterpeilen (Runhaar et al., 2020). Waterpeilheffingen zijn echter moeilijk vast te stellen, omdat de waterstand weer- en seizoensafhankelijk is. Waterschappen zijn sturend met hun peilbesluit. De oorzaak van verlaagd waterpeil kan ook buiten het handelen van de boer liggen en veroorzaakt frustratie als boeren daar alsnog op afgerekend worden (De Lauwere \& Van der Burg, 2019).

\section{Het krimpen van de veestapel}

Striktere milieu- en klimaatheffingen zullen waarschijnlijk gaan leiden tot een behoorlijke krimp van de veestapel. Boeren kunnen daarin tegemoetgekomen worden door de opkoop tegen boekwaarde van vee, veerechten, machines, vastgoed en overige liquiditeiten. De opkoop van bedrijven en veerechten is belangrijk om financiële balanswaarde van dierenrechten (Van de Sleen \& Van Benthem, 2020) en van grond te herstellen. Het verkleinen van de veestapel is namelijk essentieel om waterkwaliteit-, 
ammoniak- en klimaatdoelstellingen te halen (De Wit \& Van Veluwe, 2017; Vink et al., 2021). Doordat de mestdruk iets afneemt, heeft dit in principe ook een zeer beperkte daling van de grondprijs tot gevolg (Berkhout \& Puister, 2021). Het verkleinen van de veestapel per bedrijf draagt bij aan extensivering. In eerste instantie omdat de waarde van dierenrechten toeneemt. Maar ook als bedrijven stoppen, kan de overheid erop sturen dat de vrijkomende grond bijdraagt aan extensivering. Met gericht beleid voor ruimtegebruik, kan deze grond ter beschikking gesteld worden aan bedrijven die overblijven om hen te helpen te extensiveren (Gies et al., 2020).

\section{Groene grondbank}

Grond is vaak het grote struikelblok voor boeren die wel willen, maar niet kunnen extensiveren. Vooral veehouders hebben extra grond nodig als zij hun huidige bedrijfsomvang (aantal dieren) willen behouden. Grond in Nederland is echter schaars en daardoor zijn de grondprijzen hoog (Vrolijk et al., 2020). Ook zijn de pachtprijzen gestegen, in het eerste decennium van de $21^{\mathrm{e}}$ eeuw zelfs met $14 \%$ per jaar $^{6}$, en de pachtovereenkomsten zijn van steeds kortere duur (Schrijver et al., 2019).

Een prikkelend idee is het installeren van een groene grondbank die voorrang heeft bij het aankopen van landbouwgrond en deze vervolgens, na een periode van pacht, met voorrangsbeleid voor jonge, extensieve en natuurinclusieve boeren doorverkoopt. Op deze manier grijpt de overheid in om de marktprijs van grond te (her)stabiliseren (Van Brugge, 20 december 2020). Een wetenschappelijke verkenning naar het mechanisme van een groene grondbank binnen Nederlandse context is er momenteel nog niet. Het zou daarom verstandig zijn om dit handelingsperspectief eerst nader te onderzoeken.

\section{Transitiefonds voor extensivering}

Om veel boeren te helpen omschakelen van intensieve landbouw naar kringlooplandbouw of extensieve landbouw is het oprichten van een transitiefonds een mogelijkheid. Een transitiefonds kan primair gericht zijn op boeren, maar ook ketenpartijen zullen daar mogelijk een beroep op willen doen. Denk bijvoorbeeld aan machinebouwers die zich moeten specialiseren in duurzamere technieken zoals strokenteelt. Een mogelijkheid voor overheden is om te kiezen voor een niet-revolverend transitiefonds (Taskforce Verdienvermogen Kringlooplandbouw, 2019). Dit fonds steunt nieuwe systeeminnovaties door $80 \%$ van het risico te dragen. Daarnaast biedt het ruimte om versneld af te schrijven, zodat innovaties toegepast kunnen worden. Europese en andere subsidies vanuit de overheid kunnen volledig worden gericht op kringlooplandbouw via een gestaffelde beloning, waarbij de best presterende $10 \%$ het meest krijgt. De Taskforce adviseert om bij de toezegging van investeringen te kijken naar circulariteit en de borging van natuurlijk en sociaal kapitaal. Banken verstrekken geen financiering aan investeringen waarvan nu al duidelijk is dat die niet voldoen aan de nieuwe duurzaamheidseisen (Taskforce Verdienvermogen Kringlooplandbouw, 2019). De Transitie Coalitie Voedsel (31 maart 2021) geeft de voorkeur aan een mix van financiële instrumenten die de omslag faciliteren, zoals een stikstoffonds, een grondbank en een krediet- en garantieregeling.

\section{Sturen met pacht}

Met eigen gronden kan de overheid extensieve bedrijven ondersteunen door bij verpachting voorrang te geven aan bedrijven op kortere afstand van het perceel, met extensieve - natuurinclusieve - ambities. Hiermee kan gestuurd worden op aansluiting op brongebieden; zowel botanisch als voor weidevogels etc. (Melman et al., 2013). Ook kan de overheid korting geven op de pachtprijs bij extensief gebruik, zoals de toepassing van rustgewassen en/of rotatie in het bedrijfssysteem (Schrijver et al., 2019).

\section{Stimuleren van eigendom van natuurgrond}

Er zijn voorbeelden waar een beheervergoeding beschikbaar is gesteld voor extensieve boeren die gebruikmaken van pachtgronden van de overheid in plaats van dat boeren moeten betalen (Swormink in Polman \& Dijkshoorn, 2019). In het geval van natuurinclusieve, extensieve landbouw kan ook worden gekeken naar mogelijkheden om natuurgronden beschikbaar te stellen door middel van erfpacht (De Koeijer et al., 2018). Hiermee zijn langjarige afspraken mogelijk. Nog een optie is om mogelijkheden af te tasten voor volledig eigendom op lange termijn afbetaling. Natuurgronden in eigendom komen namelijk in aanmerking voor SNL-subsidie en daarmee is een hoger saldo/ha haalbaar (De Jong, 2020b).

\footnotetext{
6 Wageningen Economic Research Agrimatie: https://www.agrimatie.nl/binternet.aspx (selecteer pacht).
} 


\section{Toeristenbelasting ten goede van extensivering}

Steeds meer mensen trekken in hun vrije tijd naar het landelijk gebied voor recreatie. Dat betekent dat daar ook steeds meer wordt verdiend aan toerisme. Een deel van de inkomsten van de toeristenbelasting die wordt verdiend aan plattelandstoerisme zou kunnen worden ingezet voor de waarborging van de gebiedskwaliteit (Smits \& Bos, 2016). Extensieve bedrijven dragen bij aan deze gebiedskwaliteit vanwege hun lage impact op het milieu. Bovendien hebben extensieve bedrijven vaak een neventak die toeristen kan aantrekken, zoals een boerencamping of ambachtelijke workshops. Deze bijdragen verantwoorden dat toeristenbelasting ook gedeeltelijk ten goede van extensivering kan worden ingezet.

\subsubsection{Instrumenten die bijdragen aan steun van de omgeving}

\section{Gestapelde beloning via KPI-systematiek}

Het behalen van maatschappelijke opgaven is niet alleen de verantwoordelijkheid van de boer. De overheid en alle andere partijen rondom de boer hebben een verantwoordelijkheid om bij te dragen aan het behalen van maatschappelijke opgaven. Door boeren financieel te belonen voor het behalen van maatschappelijke doelen kunnen partijen rondom de boer ook bijdragen leveren. Wanneer een mix van publieke en private partijen de boer financieel beloont voor het halen van doelen, is dat een systeem van gestapelde beloning. De overheid kan een rol spelen in het organiseren van het arrangement voor stapeling en de afstemming en samenwerking tussen de partijen (Silvis et al., 2021).

Om boeren te kunnen belonen voor het behalen van maatschappelijke doelen is een monitoringssysteem nodig dat prestaties meetbaar maakt op bedrijfsniveau. Een manier om dit te doen, is via de KPI-systematiek (Van Doorn et al., 2021). Deze Key Performance Indicators (KPI's) kunnen worden gekoppeld aan een puntensysteem, waardoor boeren die meer KPI's halen een hogere score krijgen. Het puntensysteem kan vervolgens als basis dienen voor een systeem van gestapelde beloning: hoe hoger de score, des te hoger de financiële beloning. Alle partijen rondom de boer kunnen bijdragen aan een vorm van beloning. Banken kunnen boeren bijvoorbeeld korting geven op hun leningen, waterschappen kunnen korting geven op belastingen en het Rijk kan boeren korting geven op pacht (geldt ook voor andere verpachters) of meer GLB-geld vrijmaken. Daarnaast kunnen afnemers van producten meer gaan betalen als boeren hoger scoren op KPI's. Dergelijke beloningssystemen zijn in Nederland nog in ontwikkeling, maar er zijn wel al enkele voorbeelden te noemen. ${ }^{7}$

\section{Stapelen van investeringssubsidies}

Logische investeringssubsidies die boeren behoeven voor extensivering, zijn geldstromen voor de adoptie van duurzame meerjarige planten en teeltsystemen in de bedrijfsvoering (Bremmer et al., 2020) of aankoop of pacht van extra grasland voor melkveehouderij. Maar ook technologische investeringen zijn vaak nodig, zoals gps-technologie voor precisie-maaisystemen (Melman et al., 2013), geld voor de verduurzaming van landbouwwerktuigen en stalsystemen (Beldman et al., 2019; Van der Sleen \& Benthem, 2020) en de aanleg van een plas-drassysteem (Erisman et al., 2017).

Investeringssubsidies kunnen gestapeld worden tot een mix van private en publieke, of regionale, nationale en EU-betalingen (Polman \& Jongeneel, 2020). Het mixen van betalingen creëert extra betrokkenheid, en daarmee breder draagvlak in de maatschappij. In de vorige paragraaf zijn enkele voorbeelden genoemd hoe publieke gelden ingezet kunnen worden en hoe ketenpartijen een bijdrage kunnen leveren. Voor private bijdragen kunnen boeren gebruikmaken van crowdfunding (Schrijver \& Vijn, 2018; Jongeneel, 2020). Sommige boeren zijn echt meer gebaat bij crowdfunding dan andere. Verwachtingen van het succes van crowdfunding moeten daarom soms bijgestuurd worden. Cofinanciering van onderzoek door pioniers lijkt bijvoorbeeld irreëel, omdat deze startende ondernemingen al genoeg financierings- en inkomensuitdagingen op hun bord hebben liggen (Hoes et al., 2020). Daarbij komt dat het vaak alleen boeren met een bepaalde persoonlijkheid lukt om cofinanciering rond te krijgen (Drion, 2018).

\footnotetext{
7 https://www.frieslandcampina.com/nl/onze-boeren/foqus-planet https://www.vangoghnationalpark.com/biodiversiteitsmonitor
} 


\section{Investeringsruimte voor nieuwe boeren}

Het vooruitzicht van strengere milieu- en klimaatheffingen maakt voortzetting van een intensieve bedrijfsvoering voor sommige (familie)bedrijven te duur. Overschakelen naar een extensieve bedrijfsvoering zou een manier kunnen zijn om de financiële impact van deze heffingen te dempen. Extensivering kan dus op de lange termijn kosten verlagen (niet alleen door minder heffingen, maar ook door besparingen op bijvoorbeeld gewasbeschermingsmiddelen of veevoer). Op korte termijn zal een boer echter eerst moeten investeren, bijvoorbeeld door het aankopen (of pachten) van meer grond of nieuwe machines.

Investeringen om te verduurzamen of te extensiveren, zijn vaak voor nieuwe boeren niet mogelijk door de schuldenlast van hun voorganger en de daarbij opgetelde schulden die ze zelf moeten maken (De Koeijer et al., 2016). Nieuwe boeren ervaren daardoor momenteel nauwelijks beweegruimte, terwijl beweegruimte nu juist essentieel is. Rentekortingen door banken, meerprijzen vanuit ketensectoren en extra GLB-vergoedingen die momenteel worden verkend en overwogen, kunnen naar verwachting substantieel bijdragen aan de manoeuvreerruimte voor boeren om (verder) te investeren in natuurinclusieve/extensieve landbouw (Bouma et al., 2019).

\section{Opleiden een aanstellen van onafhankelijke (erf) coaches}

Boeren die overwegen te extensiveren, hebben behoefte aan advies zonder commerciële agenda en adviseurs die beschikken over een bredere kennis in relatie tot biodiversiteit (Dijkshoorn-Dekker et al., 2020; Dijkshoorn-Dekker \& Kortstee, 2020; Runhaar et al., 2020; Taskforce Verdienvermogen Kringlooplandbouw, 2019). De meeste boeren komen liever niet van hun erf af en halen hun kennis vooral uit vakbladen, internet en via erfbetreders. Erfbetreders hebben echter vaak geen belang bij extensivering of bevordering van biodiversiteit. Daarom adviseren Dijkshoorn-Dekker en Kortsee (2020) aan de overheden om te investeren in het opleiden en aanstellen van onafhankelijk erfcoaches. Naast advies over maatregelen kunnen onafhankelijke (erf)coaches ook ondersteuning bieden bij het schetsen van een rendabele extensieve landbouw-/bedrijfsvisie op grond van verdienmodellen die passend zijn voor het specifieke bedrijf (Beldman et al., 2019; Schrijver et al., 2008; 2019).

\section{Professionele agrarisch collectieven \& coöperatieven}

Gelden zoals het ANLb worden over het algemeen beschouwd als publieke goederen en worden daarom grotendeels door overheden betaald. Agrarische collectieven zijn onder andere opgericht als uitvoerende partij voor het uitbetalen van deze gelden. Ook kunnen zij een waardevolle gesprekspartner zijn voor overheden en zo op diverse manieren bijdragen aan de opbouw van motivatie en vakmanschap bij boeren (Westerink et al., 2020b). Agrarische collectieven worden echter steeds vaker gevraagd om ook buiten het ANLb om taken te vervullen. Om aan die vraag te kunnen voldoen, vereist een zeker niveau van zelfsturing en financiële stabiliteit, maar niet elk collectief is er al voldoende op toegerust om die stap te kunnen zetten (Boonstra et al., 2021). Als boeren niet deelnemen aan het ANLb, kunnen zij er ook voor kiezen om zich te verenigen in een coöperatie of Marke (Schrijver \& Vijn, 2018). Overheden kunnen bijdragen aan de professionaliteit van agrarische collectieven en coöperaties met financiële kennis, bijvoorbeeld over de transformatiekosten waar bedrijven mee te maken krijgen als zij de transitie naar zelfsturing via een coöperatie of Marke ondergaan, of door het bijhouden van een gescheiden boekhouding voor agrarische collectieven die ook op projectbasis willen werken.

\section{Rentekorting bij de bankensector voor duurzame investeringen}

Een lage rente bij de bank is voor de boer zeer belangrijk en doorslaggevend voor zijn bereidheid en manoeuvreerruimte om te verduurzamen (Drion, 2018; Drion et al., 2020). De overheid kan bij de bankensector aandringen op rentekorting voor extensieve bedrijven en investeringen; met name is dit van belang voor de melkveehouderij (Bouma et al., 2019). Melkveehouders en gemengde bedrijven zijn namelijk positiever over de rol van banken, mogelijkerwijs door de recente experimenten van banken met rentekortingen in het zuiveldomein (Koeijer et al., 2016). Daarmee is de kans dan een 'grote groep' mee wil doen, groter. Het stimuleren van de rentekorting door de overheid kan bijvoorbeeld door garant te staan voor de borgstelling van duurzame landbouwinvesteringen zoals aankoop van extra grond voor extensivering (Hoes et al., 2020). Dit jaar begint de Rabobank met een proefperiode van negen maanden waarin zij $0,2 \%$ rentekorting geeft aan melkveehouders die duurzaam ondernemen. ${ }^{8}$

\footnotetext{
8 https://www.boerenbusiness.nl/melk/artikel/10893256/rabobank-rentekorting-duurzame-melkveehouder
} 


\section{De maatschappelijke kosten van milieuschade meenemen in de productkosten}

De maatschappelijke kosten van milieuschade worden idealiter doorgevoerd in productprijzen (true pricing) (De Groot Ruiz et al., 2018; Runhaar et al., 2020; Hoes et al., 2020). Zolang de negatieve effecten van intensieve landbouw niet beprijsd zijn en zolang er minder strikte eisen gelden in het buitenland, bestaat er een dubbel ongelijk speelveld voor Nederlandse kringlooplandbouw (Taskforce Verdienvermogen Kringlooplandbouw, 2019). Door beloningen en heffingen om de verduurzaming van de consumptie te stimuleren, bijvoorbeeld door belastingen, te verschuiven van arbeid naar consumptie, worden andere keuzes van consumenten, ketenpartijen en boeren gestimuleerd. Deze doorberekende milieukosten rechtvaardigen vervolgens de meerprijs voor kwaliteits- (extensieve) producten of brengen op lange termijn deze prijs juist naar beneden (Transitie Coalitie Voedsel 31 maart 2021; Vrolijk et al., 2020).

\section{Abonnementen als verdienmodel}

Abonnementen op (pakketten van) landbouwproducten vormen een garantie voor een langdurige relatie tussen boeren en consumenten, met vaste betalingen en productlevering als tegenprestatie (Jongeneel, 2020). Dit geeft boeren meer financiële zekerheid en daarmee ruimte voor extensivering. Overheden kunnen abonnementen voor boeren stimuleren in meerdere gradaties. Kleinschalig door boeren te helpen bij het optuigen van praktijkexperimenten, bijvoorbeeld middels Community Supported Agriculture of het beginnen van een boerderijwinkel, maar ook grootschalig, door als tussenschakel een betere prijsgaranties van ketenpartijen (juridisch) af te dwingen.

\subsection{Juridische instrumenten}

\subsubsection{Instrumenten die bijdragen aan willen}

\section{Eenvoudige procedures en administratie}

Boeren vinden dat de meeste verdienmodellen van extensieve, biologische of natuurinclusieve bedrijven vaak te weinig verdienvermogen hebben in vergelijking met 'gangbare' intensieve bedrijven (Jongeneel, 2020). Daarom zijn vergoedingen en subsidies voor veel boeren nu nog een noodzakelijke aanvulling. Dat maakt boeren verplicht zich te verdiepen in bureaucratische procedures. De bureaucratische procedures rondom het aanvragen (en onderhouderhouden) van subsidie worden echter nog vaak als onduidelijk ervaren, wat frustraties opwekt. Door procedures en administratie zo eenvoudig mogelijk te houden of uit handen te geven, verhoogt de motivatie van de boer om mee te doen met duurzame maatregelen (Smits \& Bos, 2016). Dit advies kan echter op gespannen voet staan met de KPIsystematiek die eerder is genoemd.

\section{Demotiverende regels aanpassen}

Regels die tegenstrijdig zijn aan de doelen waar boeren aan werken, kunnen sterk demotiveren. Boeren die zich inzetten voor weidevogels via agrarisch natuurbeheer ergeren zich bijvoorbeeld aan de starheid van regels, zoals vastgestelde maaidata of het verbod op predatiebeheer. Veel liever maaien zij op basis van het weer, waar de vogels zitten of hoe het gras erbij staat. En door het verbod op predatiebeheer zien zij veel jonge weidevogels ondanks hun inzet alsnog verdwijnen (Westerink et al., 2018b). Regels voor agrarisch natuurbeheer zouden volgens hen beter afgestemd kunnen worden met de praktijk. Bijvoorbeeld door boeren meer autonome beslissingen te laten maken op grond van hun eigen waarnemingen en ervaring, in plaats van alles - zoals maaidata - vast te leggen in bureaucratische processen.

\subsubsection{Instrumenten die bijdragen aan kunnen}

\section{Vergunningen voor experimenten}

Experimenten betreffen vaak nieuwe praktijken waar de regelgeving nog niet op is toegespitst. Daarom kan het lastig zijn om voor experimenten de nodige vergunningen te krijgen. Bijvoorbeeld voor het voeren van dieren met reststromen of proteïne uit insecten (Hoes, 2020). De overheid zou kunnen onderzoeken welke exacte regelgeving nog meer mogelijke barrières vormen voor innovatieve ideeën die ook een bijdragen kunnen leveren aan extensivering. 


\section{Meer flexibiliteit in beheervoorschriften}

Voor extensieve bedrijven kan het beheer van natuurgronden een belangrijk stukje van de puzzel zijn. Met het beheren van natuurgronden kunnen boeren bijvoorbeeld grondgebondenheid of een lagere veedichtheid bereiken. De vaak scherpe gebruiksvoorwaarden maken inpassing echter niet eenvoudig. Dit gaat bijvoorbeeld om ruimte voor mestaanwending en (voorjaars)beweiding. Het doel - het behouden en stimuleren van een bepaald natuurdoeltype - zou echter belangrijker moeten zijn dan de regel (De Jong, 2020b). Extensieve boeren zijn door hun vakmanschap en type bedrijfsvoering vaak goed in staat om bij te dragen aan natuurdoelen, maar kunnen er spanningen ontstaan ten aanzien van de visies van TBO's.

Ook bij agrarisch natuurbeheer ervaren boeren knellende beheervoorschriften. Bijvoorbeeld in het geval van uiterste inzaaimomenten en maaidata. Geschikte momenten om te zaaien en te maaien zijn zeer weersafhankelijk en doen wederom een beroep op het vakmanschap van de boer. Strikte voorschriften werken daardoor in de praktijk vaak beknellend. Ook ten aanzien van het berijden van akkerranden zien boeren in het geval van weinig schade graag een coulanter beleid (Westerink et al., 2018b).

\section{Regiospecifiek maatwerk in pachtvoorwaarden}

In pachtcontracten voor overheids- en natuurgronden kan rekening gehouden worden met beperkingen van landschap en bodem. Daarnaast kunnen de pachtvoorwaarden aansluiten bij gebiedsgerichte doelen, bijvoorbeeld op het gebied van water en natuur. De beperkingen van het landschap en de bodem kunnen eerst worden vastgelegd in een bodempaspoort (Schrijver et al., 2020). Het paspoort bevat onder andere kwaliteitsomschrijvingen van de grond en een omschrijving van beschermde landschapselementen uit de omgeving. Deze kunnen gebruikt worden als afwegingskader voor het bepalen van bedrijfstypes of beheertypes die geschikt zijn voor een specifieke regio of gebied.

Vervolgens kan een overheid in de vorm van tenders voorwaarden stellen aan de selectie van pachters. Bijvoorbeeld het bezit van bepaalde duurzaamheidscertificaten. Extensieve bedrijfsvoering is daardoor bij voorbaat eerder geschikt dan intensieve bedrijfsvoering. Voorwaarden die gesteld worden aan de hand van beperkingen moeten zich wel vertalen in een redelijke pachtprijs.

\section{Aanpassing Pachtwet}

Verpachters zien steeds vaker af van langjarige overeenkomsten door de vergaande pachtbescherming die is opgenomen in geliberaliseerde pachtcontracten. Geliberaliseerde pacht van maximaal zes jaar leidt tot grijs/zwarte semi-informele pachtcontracten en uitputting van grond (Schrijver et al., 2019; RLI, 2020; Paul, 2021). Tegelijkertijd maken de hoge grondprijzen in Nederland het opstarten van bedrijven met minimale externe inputs erg moeilijk (Hoes et al., 2020). Nieuwe ontwikkelingen, zoals de energietransitie, dreigen de grondprijs nog verder omhoog te stuwen zonder overheidsingrijpen (Gies et al., 2020). Aanpassing van de Pachtwet kan duurzamer grondgebruik en extensivering ondersteunen. Extensieve bedrijven zijn juist gebaat bij duurzame, lange termijn pachtcontracten met voorwaarden gericht op behoud van bodemvruchtbaarheid (Hoes et al., 2020; Jongeneel, 2020; Paul, 2021; RLI, 2020; Schrijver et al., 2019).

\section{Ruimte in regelgeving}

Regelgeving is vaak toegespitst op gangbare bedrijfsvoering en daardoor vaak onnodig beperkend voor nieuwe modellen van bedrijfsvoering (Grin et al., 2015; Vrolijk et al., 2020). Zo is bijvoorbeeld Community Supported Agriculture (CSA) in opkomst, maar kent RVO nog geen code waar CSAtuinderijen in passen (Hoes et al., 2020). Ook maken de huidige Meststoffenwet en de Omgevingswet het juridisch (nog) onmogelijk om meer eigen vaste mest te gebruiken (De Lauwere \& Van der Burg, 2019). Ondernemingen met een neventak lopen tegen ook tegen knelpunten aan met de Omgevingswet. Zo is geïnventariseerd dat multifunctionele landbouwbedrijven last hebben van onduidelijkheden rondom de Drank- en Horecawet, de voorschriften van de brandweer en de onderzoeksverplichtingen voor omgevingsvergunningen (Van der Wielen et al., 2014).

\section{Beperken van de milieugebruikersruimte}

De milieugebruikersruimte bepaalt op landelijk niveau de emissieruimte voor broeikasgassen, ammoniak en $\mathrm{N}$ - en P-belasting naar het oppervlaktewater voor de landbouwsector. Om de milieudoelen die zijn vastgesteld in het Klimaatakkoord te kunnen behalen, zal de milieugebruikersruimte in Nederland beperkt worden (Vink et al., 2021). Een maatregel die hierop 
aansluit, is onder andere het extensiveren van de landbouw. Lesschen et al. (2020) hebben in vier scenariostudies voor 2050 verschillende grenzen van de milieugebruikersruimte doorberekend. Hieruit constateren zij de volgende landelijke emissiegrenzen:

- Fosfaatexcretie: de hoeveelheid P2O5 die door landbouwhuisdieren wordt uitgescheiden, mag niet hoger zijn dan 172,9 kton.

- Stikstofexcretie: de hoeveelheid stikstof die door landbouwhuisdieren wordt uitgescheiden, mag niet hoger zijn dan 504,4 miljoen kg.

- Broeikasgasemissies: de hoeveelheid broeikasgassen die door landbouw wordt uitgestoten, moet beneden een bepaald plafond blijven. Dit plafond geldt voor het totaal van methaan- en lachgasemissies en de netto LULUCF-emissie/vastlegging op landbouwgrond. De auteurs hebben scenario's uitgewerkt op basis van plafondwaarden 11 Mton CO2-eq (voorgenomen beleidsdoelen) of 2 Mton CO2-eq (striktere beleidsdoelen).

- Ammoniakemissies: de hoeveelheid ammoniak als gevolg van dierlijke productie, graslandgebruik en akkerbouw mag niet hoger zijn dan het aangegeven plafond (85 of 50 kton NH3).

Een van de maatregelen om binnen deze emissiegrenzen te blijven, is om een algemene productielimiet per hectare op te stellen (Erisman \& Verhoeve, 2020). Veel andere maatregelen zijn verbonden aan bepaalde sectoren. Hieronder zijn verschillende maatregelen per sector (melkveehouderij en akkerbouw) onder elkaar gezet. Deze maatregelen zijn met name gebaseerd op de scenariostudie van Lesschen et al. (2020), maar voor de compleetheid zijn er nog andere maatregelen bijgevoegd.

\section{Juridische maatregelen gericht op de melkveehouderij}

\section{Minder eiwitrijk krachtvoer}

Minder eiwitrijk krachtvoer zorgt ook voor een significante reductie van stikstof en ammoniak (RVO, 2021; Van der Sleen \& Benthem, 2020). Niet alleen vanwege de lagere emissiegassen die worden uitgestoten door koeien, ook omdat het aankopen van krachtvoer vaak een hoge ecologische footprint heeft (Beldman et al., 2019). Krachtvoer komt bijvoorbeeld vanuit landen zoals Brazilië en moet een lange afstand afleggen voordat het in Nederland aankomt. Erisman et al. (2017) nemen ook de mogelijkheid om over te stappen naar een volledig gras-gevoerd bedrijf in beschouwing. Om over te stappen naar een dergelijke bedrijfsvoering, zullen veel intensieve bedrijven grond moeten bijnemen. Dit kan slechts in beperkte gebieden waar het uitgangspunt van biodiversiteit laag is. Extensivering is dus niet voor elke boer een keuze. Zolang een bedrijf nog niet zelfvoorzienend in ruwvoer is, kan het effect van extensivering op de biodiversiteit dan beperkt of zelfs negatief uitpakken (Beldman et al., 2019).

Staleisen voor het verlagen van de toegestane methaanemissie in de melkveehouderij Volgens een scenario berekend door Lesschen et al. (2020) zullen stalsystemen moeten worden aangepast waarbij uitgeademde methaan kan worden afgevangen in de ligbox (16\% reductie van enterische $\mathrm{CH} 4$-emissies). Belangrijk is dat de mest gescheiden wordt. Dat betekent dat vaste mest, die weer gunstig kan zijn voor biodiversiteit, wordt gescheiden van overig methaan. Overheden zouden juridische eisen kunnen stellen aan het gescheiden opvangen van mest in stallen. Ook is het handiger als het is toegestaan om ook eigen vaste te mest te gebruiken (De Lauwere \& Van der Berg, 2019).

\section{Eisen aan grondgebondenheid in melkveehouderij}

Grondgebondenheid is een belangrijk onderdeel van kringlooplandbouw (Silvis \& Voskuilen, 2020). Overheden kunnen daarom kiezen om eisen te stellen aan grondgebondenheid in de melkveehouderij. Lesschen et al. (2020) houden voor grondgebonden melkveehouderij aan dat een bedrijf minstens $65 \%$ van de voerbehoefte van eigen of gepacht land haalt.

\section{Aanscherpen fosfaatrechten}

Minder fosfaatrechten per bedrijf kan helpen om te extensiveren, mogelijk ook in de vorm van een krimp van de veestapel (Vrolijk et al., 2020). Lesschen et al. (2020) stellen zich bij een extensief scenario het volgende voor: de hoeveelheid fosfaat en stikstof die uit- en afspoelt naar het grond- en oppervlaktewater dient beneden een bepaald gekozen plafond te blijven. Bovendien moeten fosfaatrechten ook niet van de ene sector naar de andere sector overgeheveld worden. In sommige gevallen zorgt het vooruitzicht op een lager fosfaatquotum voor zorgen en frustratie over het voortbestaan van het familiebedrijf, met name in de melkveehouderij (Berkhout \& Puister, 2021). 


\section{Wettelijk instrumentarium voor handhaving van ammoniakemissie-grens}

De overheid kan meer dwingend sturen op de noodzakelijke reductie van emissies, met name van ammoniak. Het bestaande wettelijk instrumentarium kan worden vereenvoudigd (Paul, 2021; RVO, 2021). Er moet met name gestuurd worden op een significante reductie van de N/ha/jaar. Dit kan onder meer door het verlagen van de mestaanwending (RVO, 2021). Mogelijke maatregelen bestaan uit het verdunnen van mest, het toevoegen van anorganische zuren, het verbieden van drijfmest en het vervangen van kunstmest. Een andere, uiterste mogelijkheid is een algemeen verbod op de uitspoeling van meststoffen (Hoes, 2018); deze maatregel zal echter moeilijk te handhaven zijn.

\section{Juridische maatregelen gericht op de akkerbouw}

\section{Verbod anorganische gewasbeschermingsmiddelen}

Met een verbod op anorganische gewasbeschermingsmiddelen zal de interesse van boeren in natuurinclusieve en extensieve landbouw naar verwachting pas echt op gang komen (Erisman et al., 2017; Bremmer et al., 2020). Besparing op de kosten van schadelijke inputs wordt dan onderdeel van het verdienmodel (Polman \& Dijkshoorn, 2019). Toch zal een dergelijk verbod leiden tot een - al dan niet tijdelijk - lagere opbrengst. De afzetketen zal daarin ook een rol kunnen vervullen door een betere en consequente vaste prijs te bieden.

\section{N- en P-gebruiksnormen voor akkerbouw}

Door het aanscherpen van de $\mathrm{N}$ - en P-gebruiksnormen worden akkerbouwers verplicht om hun kunstmestgift te verlagen. Dierlijke mest krijgt daardoor meerwaarde en boeren worden gestimuleerd om hun teelt aan te vullen met stikstofbindende gewassen (Lesschen et al., 2020). Mogelijke routes die afgetast kunnen worden om dit te bereiken, zijn heffingen op kunstmest en het vergunningplichtig maken van bemesting (Runhaar et al., 2020).

\subsubsection{Instrumenten die bijdragen aan steun van de omgeving}

\section{Europese afspraken vertalen naar in een Nationaal Akkoord}

Voornemens en plannen die zijn vastgelegd in de EU Green Deal kunnen als voorbeeld gebruikt worden voor een breed gedragen Nationaal Akkoord. Dit akkoord bevat een integrale langetermijnvisie en wettelijk vastgelegde doelen op het gebied van klimaat, biodiversiteit, lucht (stikstof), bodemgezondheid, water en landschap (Transitie Coalitie Kringlooplandbouw, 2019). Alhoewel het om landelijke afspraken gaat, zullen - om naar deze visie toe te kunnen werken - ook afspraken gemaakt worden met buurlanden om lokale overbelasting van grensgebieden aan de te pakken (Paul, 2021). Als bij het samenstellen van het nationaal akkoord ook alle belangrijke partijen zijn betrokken uit de agrifoodsector (landbouworganisaties, banken, voedingsindustrie etc.), is voor iedereen helder waar de stip op de horizon staat en kunnen de partijen om de boer heen meesturen richting duurzaamheid.

\section{Ketenafspraken}

Huidige Europese en nationale mededingingsregels kunnen beperkend werken op de ontwikkeling van een circulaire economie en een betere markt voor producten van extensieve bedrijven. Voor een circulaire economie zijn immers afspraken nodig in de keten en samenwerkingsverbanden tussen boeren die hun marktpositie kunnen verstevigen. Nederland zet zich in voor een gelijk speelveld voor kringlooplandbouwproducten in de gehele Europese Unie. Zolang de regelgeving op Europees niveau nog niet is aangepast, kunnen de overheid en de $\mathrm{ACM}^{9}$ informatie verstrekken over de ruimte voor samenwerking in de mededingingsregels (Taskforce Verdienvermogen Kringlooplandbouw, 2019). Enkele voorbeelden zijn www.duurzamezuivelketen.nl, www.globalgap.nl en www.sustainabilityconsortium.org (Hoes, 2018).

\section{Certificering}

Certificering of een keurmerk kan consumenten prikkelen tot het doen van duurzame aankopen en rechtvaardigt de meerprijs voor extensief geproduceerde producten (Jongeneel, 2020; De Koeijer et al., 2018). Enkele bestaande certificaten en keurmerken zijn: SKAL, On the way to Planet Proof; Beter Leven; Weidemelk; en het Milieukeurmerk plantaardig/dierlijk. Er bestaat nog geen certificering of

\footnotetext{
9 Autoriteit Consument en Markt.
} 
keurmerk specifiek voor extensieve landbouw. Keurmerken kennen drie soorten indeling: eerstegraadskeurmerken die voldoen aan de internationaal overeenkomende eisen van de Raad voor Accreditatie. Deze keurmerken worden ook wel als certificaat gezien. Voorbeelden van certificaten zijn 'biologische' en 'beschermede geografische aanduiding'. De Raad voor Accreditatie bepaalt de randvoorwaarden voor betrouwbaarheid en transparantie van certificaten. Indien partijen bijvoorbeeld niet aan bepaalde kwaliteitseisen voldoen, kan een certificaat of keurmerk worden afgenomen. Dan zijn er nog tweedegraadskeurmerken die door brancheorganisaties in het leven zijn geroepen, zoals het Wolmerk en de Keurslager. Derdegraadskeurmerken zijn logo's of tempels die de indruk wekken een keurmerk te zijn, maar dat eigenlijk niet zijn, zoals g'woon. ${ }^{10}$ Bij tweede- en derdegraadskeurmerken kan de overheid minder toezien op de kwaliteit. $^{11}$

\section{Marktregulering van stikstof- en fosfaatrechten}

Een systeem van stikstof- en fosfaatrechten kan extensivering van landbouwbedrijven bevorderen, doordat de kostprijs in de intensieve landbouw naar verhouding duurder wordt. Met een fosfaatquotum kan mogelijk meer evenwicht in de mestmarkt worden bereikt (Berkhout \& Puister, 2021; Vrolijk et al., 2020). Hetzelfde geldt voor verhandelbare NH3-rechten in de veehouderij (RVO, 2021). Voor een verantwoorde markt van stikstof- en fosfaatrechten is regie van de overheid nodig, onder meer in de vorm van effectieve, transparante en eerlijke regelgeving. Bij evaluatie en bijstelling van de huidige systemen kan aan de hand deze criteria worden bekeken in hoeverre de stikstof- en fosfaatrechten op een duurzame wijze bijdragen aan extensivering.

\section{Meer weidegang voor melkveehouderij}

Er zijn verschillende scenario's die uitgaan van een verhoging van de weidegang (RVO, 2021; Van der Sleen \& Benthem, 2020). Meer weidegang betekent ook meer behoefte aan extensivering zodat koeien voldoende gras kunnen eten. In het scenario van extensivering in de studie van Lesschen et al. (2020) wordt de weidegang voor alle dieren verhoogd naar 36.000 uur per jaar (dag en nacht).

\subsection{Hiaten: waar ontbreken handelingsperspectieven?}

Met betrekking tot alle categorieën van gedragsfactoren van boeren (het willen, het kunnen en steun van de omgeving) zijn meerdere handelingsperspectieven voor overheden gevonden (zie Tabel 1 blz. 24). Voor sommige gedragsfactoren meer dan voor andere, al zegt dat mogelijk niets over de effectiviteit of doelmatigheid van de handelingsperspectieven. Voor alle gedragsfactoren zijn overwegend meer communicatieve instrumenten gevonden. In het kader van 'willen' zijn communicatieve instrumenten vaak gericht op het verbeteren van het imago en de acceptatie van extensieve landbouw. Communicatieve instrumenten die gericht zijn op 'kunnen', betreffen vaak vaardigheden en kennis of percepties van risico en eigen kunnen. Communicatieve instrumenten die bijdragen aan 'steun van de omgeving' zijn vaak gericht op het overtuigen van andere partijen om extensieve landbouw te stimuleren en op vormen van samenwerking. Financieel-economische instrumenten zijn vaak gericht op het kunnen. Ook worden ze vaak ingezet om communicatieve instrumenten te ondersteunen met financiering en om vormen van samenwerking mogelijk te maken. Juridische instrumenten zijn vaak gericht op het beperken van intensieve landbouwactiviteiten, maar ook op het verruimen van mogelijkheden om alternatieven af te tasten. In de volgende paragrafen zullen wij dieper ingaan op de instrumenten die mogelijk nog missen. De hiaten zijn geformuleerd op grond van een lege ruimtes in de inventarisatietabel en op grond van ervaringen uit het projectteam.

\footnotetext{
10 https://www.gwoon.nl/verkooppunten/

${ }^{11}$ https://www.kcwj.nl/sites/default/files/Factsheet_Keurmerk.pdf
} 


$\begin{array}{lll}\text { Willen } & \text { Kunnen } & \text { Steun van de omgeving } \\ \text { - Handelingsperspectieven onderbouwd } & \text { - Sociaal kapitaal } & \text { - Extensief als op zichzelf staande } \\ \text { met kwalitatief onderzoek } & \text { - Technologie } & \text { sector } \\ \text { - Relatie extensivering en } & \text { - Onderzoek naar schuldenlast en } & \text { - Financiële middelen gericht op } \\ \text { bedrijfsovername } & \text { extensivering } & \text { maatschappelijke waarde } \\ \text { - Financiële onafhankelijkheid } & \text { - Grondmobiliteit } & \text { - Maatschappelijke en culturele normen } \\ \text { - Stimuleren met juridische } & \text { - Vergoedingen ten bate van de boer } & \\ \text { maatregelen } & \end{array}$

\subsubsection{Willen}

\section{Handelingsperspectieven onderbouwd met kwalitatief onderzoek}

Diverse handelingsperspectieven voor de overheid met betrekking tot het overtuigen van boeren hebben te maken met de monitoring van opbrengst-gerelateerde resultaten. Deze zijn in cijfers uit te drukken en geven over het algemeen een goede indicatie of een bepaalde maatregel wel of niet werkt op ecologisch en economisch vlak. Het voorleggen van dergelijke resultaten is een bewezen overtuigingsmiddel, maar over de sociale culturele context waarin deze maatregelen wel of niet succesvol blijken, schiet informatie echter vaak nog tekort. Het valt op hoe weinig handelingsperspectieven zijn onderbouwd met kwalitatief onderzoek, terwijl inzicht in het gedrag en de beweegredenen van boeren heel waardevol kan zijn. Farmar-Bowers en Lane (2009) onderzochten eerder aan de hand van kwalitatief onderzoek wat boeren in Australië beïnvloedt bij het nemen van beslissingen. Ook in Nederland hebben onder meer Westerink et al. (2018ab; 2019ab; 2020ab) en Runhaar et al. $(2018 ; 2020)$ een begin gemaakt voor meer verdiepend, kwalitatief onderzoek naar de sociale en culturele leefomgeving van boer. Er moet echter rekening gehouden worden met het feit dat in verschillende periodes gedurende de carrière van een boer of boerin andere factoren een rol spelen en andere soorten keuzes moeten worden gemaakt. Om deze beter te leren identificeren, is daarom langdurig en meer divers onderzoek nodig. Dit kan bijvoorbeeld door middel van het voeren van gesprekken met boeren van verschillende leeftijdscategorieën, gender, culturele achtergronden of geloofsovertuigingen. Ook kunnen boeren worden gevraagd om voor lange tijd een persoonlijk logboek bij te houden zoals is gedaan voor de samenstelling van het boek van Duffhues (2009).

\section{Relatie extensivering en bedrijfsovername}

Relatief weinig handelingsperspectieven zijn gevonden die inspelen op overwegingen rond bedrijfsoverdracht. Voor 'intensieve' boeren die aan het einde van hun carrière zijn, kan het afschalen naar extensieve landbouw een manier zijn om overname door iemand die extensief wil boeren, gemakkelijker te maken. Afschalen is met name een interessante optie voor oudere boeren, omdat zij vaak al een deel van hun schuldenlast hebben afgelost. Als zij hiertoe op tijd beslissen, kan de grond nog voor eventuele bedrijfsovername herstellen. Processen van bedrijfsovername of verkoop hangen af van de uitgangssituatie (intensief of reeds extensief), of er een opvolger is binnen of buiten de familie, wat de ambities zijn van deze opvolger, en het vreemd vermogen dat moet worden aangetrokken. Over hoe de overheid rondom bedrijfsopvolging/overname en verkoop drempels kan verlagen om te extensiveren en kansen kan vergroten, is nog weinig bekend. Dergelijke handelingsperspectieven moeten zorgvuldig omgaan met de vaak zeer emotionele aspecten van bedrijfsovername.

\section{Financiële onafhankelijkheid}

Boerenwinkels, campings en zorgfaciliteiten zorgen voor extra inkomsten en vormen vaak een belangrijk onderdeel van het verdienmodel van extensieve bedrijven. Niet alle boeren beschikken echter over de nodige vaardigheden en belangstelling om te verbreden. Sommige voelen zichzelf niet langer een 'echte boer' als de landbouwtak niet zelfstandig rendabel is. Economische afhankelijkheid van verbreding sluit daarmee een groep boeren uit van kansen voor extensivering. Er zijn nog weinig handelingsperspectieven die gericht inspelen op verschillen tussen boeren als het gaat om trots en persoonlijke interesse.

Een andere belangrijke poot onder het verdienmodel van extensieve bedrijven is inkomsten uit natuurbeheer en agrarisch natuurbeheer. Sommigen ervaren een psychologische drempel om 
'afhankelijk te worden van subsidies'. Het voelt voor hen tegenstrijdig aan hun autonomie als boer. Relatief weinig handelingsperspectieven spelen in op versterking van de autonomie van de boer, of adresseren de demotiverende kanten van financiële prikkels.

\section{Stimuleren met juridische maatregelen}

Dat juridische instrumenten demotiverend kunnen werken is logisch, want juridische middelen werken veelal beperkend. Dat neemt niet weg dat juridische middelen ook kunnen worden ingezet om te stimuleren. Stimulerende juridische handelingsperspectieven, die bijvoorbeeld gebruikmaken van gedragsinzichten over hoe regels persoonlijke normen kunnen ondersteunen, zijn tot nu toe zeer schaars.

\subsubsection{Kunnen}

\section{Sociaal kapitaal}

Boeren met meer sociaal kapitaal ervaren over het algemeen meer manoeuvreerruimte om andere duurzame manieren van bedrijfsvoering af te tasten. Dit komt omdat zij zich gesteund voelen door hun sociale netwerk. Tot nog toe zijn netwerk-faciliterende handeling perspectieven echter vooral gericht op kennisdeling en het opdoen van praktijkervaring. Al hoewel hierbij ook sprake is van een vergroting van sociaal kapitaal, beperken netwerkinitiatieven zich vaak tot boeren die zich al actief sociaal mengen. Juist met het oog op de boeren die niet uit zichzelf geneigd zullen zijn om buiten hun erf te treden, zijn handelingsperspectieven voor het opbouwen van sociaal kapitaal interessant.

\section{Technologie}

Extensieve landbouw vraagt om een andere toepassing van technologie. In plaats van grote, zware landbouwwerktuigen zijn bijvoorbeeld juist kleinere, wendbare werktuigen nodig. Dit soort werktuigen zijn er soms ook nog niet. Denk bijvoorbeeld aan machines voor strokenteelt of sensortechnieken die data verzamelen over de bodemgesteldheid. In eerste instantie is hier dus een handelingsperspectief voor meer onderzoek en productontwikkeling. Ten tweede zijn personen die boeren advies geven over technologische innovaties (zoals erfbetreders) zich niet altijd bewust van alle mogelijkheden, of ze doen aanbevelingen in het belang van een werktuigleverancier die geen baat heeft bij advies voor extensivering. Ten derde is er nog weinig bekend over de investeringsbehoefte voor extensivering op technologisch vlak. Vooralsnog wordt er vooral van uitgegaan dat extensivering leidt tot besparing van fossiele brandstoffen en zware landbouwwerktuigen. De aanschafkosten van lichtere en 'slimmere' landbouwwerktuigen die de extensieve landbouw kunnen optimaliseren, zijn nog niet berekend. Daaruit zouden handelingsperspectieven kunnen worden onderzocht om in deze investeringsbehoefte tegemoet te komen.

\section{Onderzoek naar schuldenlast en extensivering}

Er is nog weinig kennis over hoe schuldenlasten van boeren zich verhouden tot hun mogelijkheden voor extensivering en wat de overheid kan doen om die belemmeringen weg te nemen. Jongeren hebben naar eigen zeggen een hogere schuldenlast om te investeren in verduurzaming doordat zij de schulden die hun ouders hebben gemaakt om te intensiveren, overerven. Anderzijds houden de huidige fiscale vrijstellingen van inkomstenbelasting, vennootschapsbelasting, erf- en schenkbelasting de grondprijzen hoog. Die belastingen zijn gericht op voortzetting van het huidige bedrijf, ongeacht of de bodem wel of niet duurzaam wordt gebruikt, wat leidt tot verdere intensivering (RLI, 2020). Mogelijk zal er dus moeten worden gezocht naar handelingsperspectieven met vooropgestelde duurzame randvoorwaarden die schuldenlast voor jonge boeren die geïnteresseerd zijn in een bedrijfsovername kunnen verlagen.

\section{Grondmobiliteit}

De behoefte aan grond is overduidelijk het grootste obstakel voor extensivering.

Handelingsperspectieven zijn met name gericht op het verlagen en stabiliseren van de grondprijs, maar er gaat nog te weinig aandacht uit naar de juridische aspecten van grondmobiliteit. Dit hiaat vorm met name een barrière voor boeren zonder opvolger en/of 'gestopte' boeren. De afbouw van het bedrijf door stoppende boeren en of boeren zonder opvolger gebeurt vaak in drie fases:

1. Stoppen met melken/ verkoop vee;

2. Verkoop delen van de grond te beginnen met veldkavels (verder van het bedrijf gelegen gronden);

3. Verkoop alle grond/bedrijfsgebouwen (soms exclusief het woonhuis). 
In de $1 \mathrm{e}$ en $2 \mathrm{e}$ fase gebeurt het vaak dat er bijvoorbeeld een schapen- of vleesveetak wordt opgezet of uitgebreid en/of jongvee-opfok voor derden wordt gedaan. Eventueel in combinatie met verkoop grasgewas/aanvoer mest. Overtollige gronden wil men wel verhuren, maar dit loopt tegen fiscale problemen op.

1. Door het verhuren van grond (vanuit de onderneming) is de waardestijging op de grond belast.

2. Het verhuren van grond vanuit privé in Box 3 is belast ( $33 \%$ van $5,33 \%$ van de waarde in het economisch verkeer). Hiermee zal een groot deel van de pachtopbrengst verdampen en blijft er nauwelijks rendement over (Arvalis, 16 september 2019).

Door de fiscale regels aan te passen (bv. een tijdelijke vrijstelling van 10-12 jaar) zou de grondmobiliteit (het in gebruik geven en of verhuren van grond) en daarmee de bedrijfsontwikkeling van 'doorgaande' boeren aanzienlijk kunnen toenemen.

\section{Vergoedingen ten bate van de boer}

Sinds vergoedingen van de GLB gekoppeld zijn per hectare, zijn er onderhandelingen ontstaan met verpachtende partijen en worden er steeds vaker geliberaliseerde pachtcontracten afgesloten. Door de premie te koppelen aan grond krijgt die grond meer waarde ten opzichte van grond waarvoor geen premie kan worden verkregen. In economische termen heet dit een 'rent'. Het gevolg is dat bij toekomstige grondaankopen de koper een hogere prijs zal moeten betalen, daardoor hogere kosten heeft en dat het inkomensvoordeel voor deze nieuwe eigenaar dus teniet wordt gedaan. Het inkomenseffect is omgezet in een vermogenseffect. Deze constructie draagt eraan bij dat 'boeren arm leven en rijk sterven'. Pachters die worden geconfronteerd met een geliberaliseerde pacht zullen het effect ook meteen merken, zeker als de druk op de lokale grondmarkt hoog is.

De manier van belonen van ecosysteemdiensten (en voor extensivering) kan dus ook grote gevolgen hebben voor het inkomen van boeren. Hoe de overheid hierin handelt, doet ertoe.

Handelingsperspectieven waarbij de beloning wordt gekoppeld aan grond, koppelen die beloning in eerste instantie aan de factor kapitaal en niet aan de factor arbeid. Desgewenst kan daaraan wat worden gedaan. Voor levering van ecosysteemdiensten is doorgaans zowel grond als arbeid nodig. Een aanpak zoals voorgesteld in Boeren voor Natuur kan daarbij helpen, waarbij enerzijds (vergelijkbaar met de regeling functieverandering) een fonds wordt gecreëerd voor 'de afwaardering' en anderzijds (anders dan in de regeling functieverandering - die vrij besteedbaar is) vanuit dat fonds langdurig een jaarlijkse vergoeding voor de te leveren arbeid wordt gegenereerd. Bij de regeling functieverandering bestaat op termijn het risico dat de grond inderdaad minder waard wordt en dat de benodigde arbeid voor het leveren van de ecosysteemdiensten alsnog een last wordt. Boeren voor Natuur tracht die valkuil te vermijden (Westerink et al., 2013, 2018a).

\subsubsection{Steun van de omgeving}

\section{Extensieve landbouw als op zichzelf staand ontwikkelpad}

Communicatieve handelingsperspectieven op het gebied van netwerkverbreding, pilots en livings labs zijn tot nu toe veelal toegespitst op specifieke vormen van extensieve landbouw, zoals kringlooplandbouw, natuurinclusieve landbouw en/of biologische landbouw, maar nog niet op extensieve landbouw als op zichzelf staand ontwikkelpad. Het ontbreekt dan ook nog aan een extensieve landbouwlobby (Runhaar et al., 30 april 2020). Het gaat in deze zin dus niet per se om het ontbreken van handelingsperspectieven, maar met name om het ontbreken van communicatie met betrekking op extensieve landbouw. Dit uit zich bijvoorbeeld in het gebrek aan concrete intentieverklaringen voor het extensiveren van landbouw, met name tussen overheden en andere partijen in de agrifoodsector. Mogelijk kan in Europa extensivering gekoppeld worden aan de Green Deal. Ook ontbreekt het nog aan campagnes specifiek gericht op het extensiveren van landbouwpraktijken door boeren. Wel zijn er aanbevelingen voor het gericht benadrukken van vakmanschap en de boerencultuur (Westerink et al., 2018), maar deze zijn nog niet omgezet tot concrete campagnestrategieën. Campagnes die tot nu toe zijn aanbevolen, zijn vooral gericht op het bewust maken van consumenten van het effect van hun koopgedrag. 


\section{Financiële middelen gericht maatschappelijke waarde}

Extensivering is een duurzame investering. Dat betekent dat het bedrijfssysteem voor een zeer lange tijd mee kan gaan en naarmate de tijd verloopt, steeds minder investeringskosten behoeft. Dat vooruitzicht geeft rust, al helemaal als milieu- en klimaatheffingen steeds duurder worden en emissiegrenzen worden aangescherpt. Toch lijken veel boeren niet te willen extensiveren, omdat een extensieve bedrijfsvoering naar hun zeggen te weinig verdienvermogen oplevert (Jongeneel, 2020). Er is echter nog weinig inzicht in waar een verdienmodel minimaal aan moet voldoen om boeren voldoende perspectief te bieden om de stap te wagen. Mogelijk zou het concretiseren van uitbetalingen voor ecosysteemdiensten een uitkomst kunnen zijn om boeren toch over de streep te trekken. Zaken zoals de kosten voor omschakeling kunnen dan eventueel beter worden gerechtvaardigd. Het lijkt er echter op dat daar nog een maatschappelijke discussie aan vooraf zal gaan, met name over wie voor de diensten moet betalen. Daarnaast is de kans groot dat sommige boeren in de toekomst meer zullen profiteren van een transitie dan andere. Om hierop te anticiperen, is er behoefte aan handelingsperspectieven om de maatschappelijke discussie in goede banen te leiden en kansongelijkheid te verminderen.

\section{Maatschappelijke en culturele normen}

Landbouw, natuur- en waterbeheer worden binnen het regime van de gangbare landbouw (en dat van traditioneel natuurbeheer en klassiek waterbeheer) gezien als functioneel van elkaar gescheiden werelden (Grin et al., 2015). Hieraan ten grondslag ligt een normatieve opvatting. Zo praten we over 'cultuurgrond' en 'natuurgrond'. In de praktijk betekent dit dat de 'gangbare' boer zich met name bezighoudt met het levend en gezond houden van zijn vee, gewas of grasland en niet (altijd) met eventuele negatieve bijkomstigheden van zijn werk, zoals verlies van biodiversiteit of klimaatverandering. Het bewustzijn binnen en buiten de landbouw groeit echter dat een integrale benadering nodig is. Maar zolang intensieve landbouw nog steeds het beginpunt is van waaruit wordt geredeneerd (in rekenmodellen, databases, subsidieregelingen, regelgeving, financiering etc.), blijven extensieve vormen van landbouw gereduceerd tot 'alternatieve' vormen van landbouw. Om dit te veranderen, dient het uitgangspunt van het gesprek, en daarmee ook de normatieve opvattingen over het agrarisch gebied, aangepakt te worden. 


\section{Discussie}

\subsection{Beperkingen van het onderzoek}

Deze inventarisatie is niet compleet. Het is goed mogelijk dat er bij de literatuurstudie bronnen over het hoofd zijn gezien. Dat komt enerzijds door de versnippering aan extensieve landbouwactiviteiten, anderzijds door de relatief nieuwe aandacht voor het onderwerp. Zoals eerder is beschreven, kent extensieve landbouw geen eenduidige invulling. Dat maakt dat voor het inventariseren van handelingsperspectieven, meerdere aanbevelingen vanuit meerdere invalshoeken zijn onderzocht. Het is goed denkbaar dat binnen het tijdsbestek dat ons is gegeven een bepaalde invalshoek ons is ontgaan, of slechts beperkt is afgetast. Bovendien wordt extensivering pas sinds relatief korte tijd als serieuze noodzaak gezien, waardoor nog weinig is nagedacht over bijvoorbeeld een goede opeenvolging van handelingsperspectieven.

Veel literatuur rondom extensieve vormen van landbouw is grotendeels beschouwend van aard. Dit gaf vaak een interessante kijk op de noodzaak tot extensivering, maar zorgde er ook voor dat er soms tussen de regels door moest worden gezocht naar concrete handelingsperspectieven. Voor een betere doorwerking van kennis in beleid, kunnen onderzoekers beleidsmakers helpen door vaker concrete aanbevelingen te formuleren op basis van hun onderzoek.

Een belangrijke beperking van dit onderzoek is het ontbreken van een beoordeling van de geïnventariseerde handelingsperspectieven. We hebben ons beperkt tot het maken van een overzicht en het identificeren van hiaten. We hebben de gevonden handelingsperspectieven niet beoordeeld op kwaliteit van de beleidstheorie, noch op mogelijke ongewenste effecten en trade-offs. Het is op basis van dit onderzoek nog niet mogelijk om prioriteiten aan te wijzen met betrekking tot handelingsperspectieven.

\subsection{Extensivering: geen doel op zich}

In dit onderzoek is extensivering als route voor verduurzaming van (een deel van) de landbouwsector in (een deel van) Nederland als uitgangspunt genomen op basis van een vraag van de beleidsdirectie van LNV. Extensivering is echter een complex proces met mogelijk gunstige effecten op milieu en biodiversiteit, maar waarschijnlijk ook negatieve effecten. Een forse krimp van de veestapel zal bijvoorbeeld zonder twijfel grote gevolgen hebben voor het gehele agrocomplex. Berkhout en Puister (2021) verwachten dat onder meer de werkgelegenheid en de totale economische toegevoegde waarde in het agrocomplex zullen afnemen. Bij ieder beschreven handelingsperspectief zijn, behalve een positieve invloed op extensivering, eveneens nadelige effecten of risico's te verwachten. Mogelijk lopen de meningen over die voor- en nadelen uiteen, zoals met de ontwikkeling van KPI's, waar sommigen een verlichting, anderen juist een verzwaring van de regeldruk verwachten.

Bij het verder uitwerken van een strategie voor extensivering raden wij dan ook aan om de doelen voor ogen te houden en extensivering als een middel te blijven zien dat een adaptieve strategie en maatwerk nodig heeft. De strategie zal bestaan uit combinaties van handelingsperspectieven. Tegelijkertijd gaat het om een strategie voor de lange termijn, waar alle partijen in de keten duidelijkheid over moet worden geboden en waar het nodig is om verliezers een uitweg te bieden. Bij een adaptieve strategie hoort monitoring, evaluatie en bijstelling van het beleid. 


\subsection{Resterende onderzoeksvragen}

Aan deze inventarisatie zijn meerdere vervolgvragen verbonden. Allereerst ligt er een opgave bij het onderzoeken van handelingsperspectieven die aansluiten op de geïdentificeerde hiaten. Ten tweede ligt er een onderzoeksopgave in het bepalen van een samenhang van de al voorgelegde handelingsperspectieven. Het is duidelijk dat er al diverse mogelijkheden zijn voorgedragen om extensivering te bevorderen, maar hoe deze elkaar kunnen versterken of tegenwerken, is nog niet inzichtelijk. Dit kan gaan om combinaties of een goede volgorde van handelingsperspectieven. Ook is nog niet duidelijk welke handelingsperspectieven prioriteit moeten hebben over andere, omdat ze effectiever of eerlijker zijn. Verder is nog weinig zicht op trade-offs van de handelingsperspectieven en op het benodigde maatwerk in specifieke situaties.

Deze vragen kunnen het best worden onderzocht in de praktijk. Dat kan kleinschalig, in pilots, living labs, studiegroepen of andere experimentele vormen, en in sommige gevallen juist op grotere schaal. 


\section{$5 \quad$ Conclusie}

In dit onderzoek stonden de volgende vragen centraal: Wat zijn handelingsperspectieven voor de overheid voor het stimuleren van extensivering van de landbouw? En welke kennislacunes bestaan ten aanzien van handelingsperspectieven voor extensivering? Handelingsperspectieven zijn in beeld gebracht op basis van aanbevelingen in de literatuur en geordend naar type instrumenten: communicatieve, financieel-economische en juridische instrumenten. Bovendien zijn ze geordend naar hun invloed op factoren die een rol spelen bij keuzes van boeren, in de categorieën willen, kunnen en steun van de omgeving. Door deze ordening ontstond zicht op hiaten met betrekking tot de aansluiting van handelingsperspectieven op gedrag.

Voor alle categorieën van gedragsfactoren zijn handelingsperspectieven voor extensivering gevonden en voor alle typen instrumenten ook. Een deel van de handelingsperspectieven zit al in de beginfase van uitvoering, de meeste kunnen echter geïnterpreteerd worden als 'potentiële' maatregelen. De weg naar extensieve landbouw lijkt daarmee misschien al behoorlijk te zijn uitgestippeld, maar welke concrete paden het best als eerst betreden kunnen worden, is nog onduidelijk.

De meeste communicatieve handelingsperspectieven zijn gericht op het stimuleren van bewustwording, netwerken en samenwerking. Daarbij wordt met name gestuurd op het herkennen van extensieve praktijken, bijvoorbeeld door middel van kennisuitwisseling en praktijkvoorbeelden, maar ook op het erkennen en verder ontwikkelen van boerenvakmanschap, bijvoorbeeld door extensief op te nemen in het landbouwonderwijs en te wijzen op boeren die vooroplopen in hun omschakeling naar extensieve landbouw. Boeren nemen kennis het best ter harte als het van personen komt die dichtbij hen staan. Landbouwcollectieven of coöperaties zijn daarom belangrijke instituten die erop kunnen sturen dat boeren met elkaar in contact komen. Het meest benadrukte communicatieve handelingsperspectief is echter het formuleren van een eenduidige langetermijnvisie. Met een eenduidige visie als uitgangspunt kunnen handelingsperspectieven voor het in kaart brengen van mogelijkheden om met elkaar (overheid, ketenpartijen en burgers) tot die visie te komen makkelijker worden uitgevoerd.

Financieel-economische instrumenten kunnen met name helpen bij het wegnemen van onzekerheden. Deze onzekerheden spelen vooral in de transitiefase, als de opbrengsten van extensieve landbouw (nog) niet opwegen tegen de investeringen van omschakeling en de lagere inkomsten. Innovatieve ideeën voor een Groene grondbank en een Transitiefonds kunnen extensiveren mogelijk helpen maken, maar vragen nog om meer wetenschappelijke onderbouwing. Ook kunnen boeren met subsidies beloond worden voor het leveren van ecosysteemdiensten of agrarisch natuurbeheer. KPI's worden daarbij vaak als meetinstrument genoemd. Subsidies zijn echter aan verandering onderhevig en kunnen schuren met een gevoel van autonomie, waar sommige boeren veel waarde aan hechten. Structurele veranderingen zullen vooral gepaard gaan met veranderingen in het GLB. Met veranderingen in het GLB kan bijvoorbeeld verdere homogenisering van landbouwpraktijken worden voorkomen.

Juridische handelingsperspectieven kunnen alleen als legitiem ervaren worden als het doel waartoe zij dienen duidelijk is en geaccepteerd wordt. Om echt grote stappen te kunnen maken in de omschakeling naar een duurzaam landbouwsysteem kunnen strenge milieugrenzen worden gesteld. Voor het gehele agrocomplex zal dit grote gevolgen hebben. Niet alleen voor wat er nog wel - en vooral niet - kan, maar ook voor wat een 'goede boer' zijn gaat inhouden.

Alle beschreven handelingsperspectieven hebben beperkingen. Ze kunnen elkaar tegenwerken en aanvullen. Grond speelt bijvoorbeeld bij mogelijkheden voor extensivering een grote rol. Inzet van grondinstrumenten ten bate van extensivering van bedrijven door uitbreiding met grond heeft echter alleen zin als de omstandigheden voor milieu en biodiversiteit daarmee verbeteren. Boeren kunnen aangemoedigd worden om deze omstandigheden te verbeteren met behulp van KPI's. Dit kan echter de administratieve druk verhogen. Ook is grond in Nederland erg duur en demotiveren geliberaliseerde pachtcontracten boeren om langetermijnmaatregelen te nemen. Subsidies kunnen helpen om een deel 
van de kosten voor extensivering te dekken, maar zijn vaak tijdelijk van aard. Handelingsperspectief moet dus vooral gezocht worden in een goed doordachte mix van instrumenten.

Het vaststellen van één duidelijke visie op de toekomst van de landbouw zou een grote invloed kunnen hebben op de gehele landbouwsector. De boer zal om binnen de grenzen van het Klimaatakkoord te kunnen blijven niet meer alleen in ons voedsel voorzien, hij zal ook beschermer worden van de draagkracht van zijn land. Extensiveren kan een manier zijn om die draagkracht te optimaliseren. Om boeren te ondersteunen beschermer te worden van de draagkracht van zijn of haar land zal niet alleen de overheid, maar zullen ook ketenpartijen en burgers een bijdragen moeten leveren. Boeren nemen immers het meeste aan van hun directe omgeving. De grootste veranderingen kunnen soms beginnen met een gesprek aan de keukentafel. Hoe meer mensen daarom hun waardering uitspreken over extensieve landbouw, hoe groter de kans is dat de interesse hiervoor zal worden aangewakkerd. Met andere woorden: handelen volgens natuurlijk draagkracht vergt collectief draagvlak en daadkracht. 


\section{Literatuur}

Akkoord Samen Werkt Beter: Samen Werkt Beter - Provincie Overijssel.

Agricola, H., Schrijver, R., Westerink, J., \& van Eldik, Z. (2021). Typering extensieve landbouw in Nederland. (Rapport / Wageningen Environmental Research; No. 3062). Wageningen Environmental Research. https://doi.org/10.18174/541710

Arvalis (16 september 2019). Wijzigingen is box 3: gevolgen bij (ver)huur van landbouwgrond. https://www.arvalis.nl/wijzigingen-in-box-3-gevolgen-bij-verhuur-van-landbouwgrond/

Beldman, A., Polman, N., Kager, H., Doornewaard, G., Greijdanus, A., Prins, H., ... \& Koppenjan, J.(2019). Meerkosten biodiversiteitsmaatregelen voor melkvee-en akkerbouwbedrijven (No. 2019-105). Wageningen Economic Research.

Berkhout, P., \& de Puister, L. (2021). Sociaal-economische gevolgen van diverse beleidsinstrumenten voor de agrarische sector. Wageningen University \& Research.

BIN-NL, 2019. Rijk aan gedragsinzichten: editie 2019. Behavioural Insights Netwerk Nederland BoerenNatuur over hun leernetwerken: https://www.boerennatuur.nl/wat-doen-we/kennis-delen/ Booij, A. (2015). Weiden mag melk kosten. Veeteelt Gras Extra September 2015, 2-35.

Boonstra, F.G, F.G Boonstra, W Nieuwenhuizen, T Visser, T Mattijssen, F.F. van der Zee, R.A Smidt, et al. 2021. Stelselvernieuwing in Uitvoering: Tussenevaluatie Van Het Agrarisch Natuur- En Landschapsbeheer. Rapport / Wageningen Environmental Research, 3066. Wageningen: Wageningen Environmental Research. https://doi.org/10.18174/541699.

Bouma, J., Koetse, M., Polman, N., \& Brandsma, J. (2019). Financieringsbehoefte natuurinclusieve landbouw: rapportage eerste fase: beschrijvende analyse vragenlijst. PBL Planbureau voor de Leefomgeving.

Bremmer, J., Hoes, A. C., de Lauwere, C., \& Smit, B. (2020). Van kwetsbaar naar weerbaar: het Uitvoeringsprogramma Toekomstvisie Gewasbescherming 2030 belicht vanuit transitietheorie (No. 2020-059). Wageningen Economic Research.

Buizer, I. M., Arts, B., \& Westerink, J. (2016). Landscape Governance as Policy integration 'from below': a case of displaced and contained political conflict in the Netherlands. Environment and Planning $\mathrm{C}$. Government and Policy, 34(3), 448-462. https://doi.org/10.1177/0263774X15614725

Burg, A.B. van den, F. Berendse, H.F. van Dobben, J. Kros, R. Bobbink, J. Roelofs, B. Odé, C.A.M. van Swaay, H. Sierdsema, H.N. Siebel en W. de Vries, 2021. Stikstof en natuurherstel. Onderzoek naar een ecologisch noodzakelijke reductiedoelstelling van stikstof. Wereld Natuur Fonds.

Burton, R.J.F., 2004. Seeing through the 'good farmer's' eyes: Towards developing an understanding of the social symbolic value of 'productivist' behaviour. Sociologia Ruralis 44, 195-215.

Burton, R.J.F., Kuczera, C., Schwarz, G., 2008. Exploring farmers' cultural resistance to voluntary agrienvironmental schemes. Sociologia Ruralis 48, 16-37.

Dessart, F.J., Barreiro-Hurlé, J., van Bavel, R., 2019. Behavioural factors affecting the adoption of sustainable farming practices: a policy-oriented review. European Review of Agricultural Economics $46,417-471$.

Dijkshoorn-Dekker, M., \& Kortstee, H. (2020). Een breder bereik van kennis en innovatie: Kennisdeling en leren rond biodiversiteit binnen de kringlooplandbouw (No. 2020-063). Wageningen Economic Research.

Dijkshoorn-Dekker, M., Dijkshoorn-Dekker, M., Kortstee, H., Linderhof, V., Kortstee, H., \& Linderhof, V. (2019). Samen bouwen aan een duurzaam voedselsysteem: transition support system-aanpak voor een gezamenlijk perspectief voor overijssel (Ser. Publicatie / wageningen economic research, 2019091). Wageningen Economic Research. https://edepot.wur.nl/502019.

Dijkshoorn-Dekker, M., Polman, N., Beldman, A., Doorneweerd, G., Janssens, B., Dekking, A., \& de Wolf, P. (2020). Biodiverse bedrijfsvoering: Praktische maatregelen en cijfers voor akkerbouw en melkveehouderij (No. 2020-106). Wageningen Economic Research.

Drion, S. (2018). Financing future farming an exploration of alternative financing constructions to enhance sustainability at farm level. Msc-thesis Wageningen University, Wageningen. 
Drion, S., van Boxtel, M., Vijn, M., \& van der Meulen, H. (2020). Financiering voor duurzame landbouwbedrijven: Geld aantrekken op de sociale en ecologische waarden die jij als boer creëert. Wageningen University \& Research.

Duffhues, T., Pieper, H., Ploum, F. (2009). Waarde van het land: verhalen van boeren en burgers over het platteland. Uitgeverij Ten Have. EAN 9789025960353.

Duinkerken, G. van, G.J. Remmelink, H. Valk, K.M. van Houwelingen \& K. Hettinga, 2005. Beheersgraskuil als voeder voor melkgevende koeien. Praktijk Rapport Rundvee 77 Animal Science Groep, Wageningen UR.

Duncan, J., Carolan, M. S., \& Wiskerke, J. S. C. (Eds.). (2021). Routledge handbook of sustainable and regenerative food systems. Routledge.

Erisman, J. W. and Verhoeven, F. (2019) Kringlooplandbouw in de praktijk: analyse en aanbevelingen voor beleid. Bunnik: Louis Bolk Instituut en Boerenverstand.

Erisman, J. W. en Slobbe, R. (2019). Biodivers boeren: de meerwaarde van natuur voor het boerenbedrijf. Jan van Arkel.

Erisman, J. W., \& Verhoeven, F. (2020). Integraal op weg naar kringlooplandbouw 2030.

Erisman, J. W., van Eekeren, N., van Doorn, A., Geertsema, W., \& Polman, N. (2017). Maatregelen natuurinclusieve landbouw (No. 2821). Wageningen Environmental Research.

Farmar-Bowers, Q., \& Lane, R. (2009). Understanding farmers' strategic decision-making processes and the implications for biodiversity conservation policy. Journal of environmentalmanagement, 90(2), 1135-1144.

Fresco, L. O., \& Poppe, K. J. (2016). Towards a common agricultural and food policy. Wageningen University \& Research.

Gies, E., Lesschen, J. P., Kros, H., \& Voogd, J. C. (2020). Verkenning naar ruimtegebruik landbouw 2050 voor Regio Foodvalley: regionale ruimtelijke uitwerking van WUR-scenariostudie Landbouw in Nederland in 2050 (No. 3042). Wageningen Environmental Research.

Graaf, H. van de \& Hoppe, R., 1996. Beleid en Politiek. Een inleiding tot de beleidswetenschap en beleidskunde, 3e druk, Bussum: Coutinho.

Grin, J., Polman, N. B. P., Dijkshoorn-Dekker, M. W. C., \& Vogelzang, T. A. (2015). Verdienmodellen voor Natuurinclusieve landbouw. Wat ondernemers al doen, en wat de overheid kan doen om opschaling te bevorderen (No. 2015-044). LEI Wageningen UR.

Grinsven, H. J. van, Erisman, J. W., de Vries, W., \& Westhoek, H. (2015). Potential of extensification of European agriculture for a more sustainable food system, focusing on nitrogen. Environmental Research Letters, 10(2), 025002.

Groot Ruiz, Adrian de, Willy Baltussen, Reinier de Adelhart Toorop, Floor van den Elzen, Bas Janssen, Roland van Keeken, et al. 2018. Op Weg Naar De Echte Prijs, Echte Waarde En Echte Winst Van Voedsel: Een Routekaart Om Te Sturen Op De Maatschappelijke Effecten Van Voedsel. Wageningen Economic Research Rapport, 2018-016. Wageningen: Wageningen Economic Research. https://doi.org/10.18174/445777.

Herzele, A. van, Gobin, A., Van Gossum, P., Acosta, L., Waas, T., Dendoncker, N., Henry de Frahan, B., 2013. Effort for money? Farmers' rationale for participation in agri-environment measures with different implementation complexity. Journal of Environmental Management 131, 110-120.

Heublein, C., Dohme-Meier, F., Südekum, K., Bruckmaier, R., Thanner, S., \& Schori, F. (2017). Impact of cow strain and concentrate supplementation on grazing behaviour, milk yield and metabolic state of dairy cows in an organic pasture-based feeding system. Animal, 11(7), 1163-1173. doi: $10.1017 /$ S1751731116002639

Hoekstra, N., Holshof, G., Zom, R., Philipsen, B., Schils, R., \& van Eekeren, N. (2020). The effect of grazing system and level of concentrate protein feeding on milk production and $\mathrm{N}$ use efficiency of dairy cows on peat meadows. Sustainability (Switzerland), 12(3), [1055]. https://doi.org/10.3390/su12031055

Hoes, A. C., Slegers, M., Savelkouls, C., Beldman, A., Lakner, D., \& Puister-Jansen, L. (2020). Toekomstige voedselproductie: een portret van pionierende boeren die bijdragen aan kringlooplandbouw in Nederland (No. 2020-019). Wageningen Economic Research.

Hoes, A-C. (2018). Voedselsysteeminnovatie: kansen voor een duurzamer en gezonder Nederland. Wageningen Economic Research. https://doi.org/10.18174/456111

Holster, H. C., van Opheusden, M., Gerritsen, A. L., Kieft, H., Kros, H., Plomp, M., Verhoeven, F., de Vries, W., van Essen, E., Sonneveld, M. P. W., \& Venekamp, A. (2014). Kringlooplandbouw in Noord-Nederland: van marge naar mainstream. Wageningen UR. https://edepot.wur.nl/288027 
Johansson, M., Rahm, J., Gyllin, M., 2013. Landowners' Participation in Biodiversity Conservation Examined through the Value-Belief-Norm Theory. Landscape Research 38, 295-311.

Jones, R., Pykett, J., Whitehead, M., 2013. Psychological governance and behaviour change. Policy and politics 41, 159-182.

Jong, K. de (2020)a. Arbeidsinkomen extensieve boeren 30.000 euro minder. PPP AgroAdvies.

Jong, K. de (2020)b. Realiseren door te stimuleren. PPP AgroAdvies.

Jongeneel, R. A. (2020). Verdienmodellen: actualiteit, theorie, praktijken en beleid. Wageningen Economic Research. https://edepot.wur.nl/530231

Jongeneel, R., \& Baltussen, W. (2019). Programmeringsstudie eerlijke, echte prijs en verdienvermogen. Wageningen University \& Research.

Jongeneel, R.A., Polman, N.B.P., Slangen, L.H.G., 2008. Why are Dutch farmers going multifunctional? Land Use Policy 25, 81-94.

Kleijn, D., \& en Natuurbeheer, P. (2018). Position paper GLB tbv rondetafelgesprek 11 oktober 2018. Wageningen Universiteit, Wageningen.

Koeijer, T. de, Blokland, P. W., Bos, E., Greijdanus, A., \& Smits, M. J. (2018). Verkenning potentiële bijdrage pacht natuurgrasland aan natuurinclusieve landbouw: Een modelmatige bedrijfseconomische analyse (No. 2018-058). Wageningen Economic Research.

Koeijer, T. de, Helming, J., Luesink, H., \& Schulte, R. (2017). Mestbeleid en mestmarkt: een kwalitatieve analyse van de ex-ante Evaluatie Meststoffenwet 2016 (No. 2017-003). Wageningen Economic Research.

Korevaar, H. (2006). Perspectieven van veranderend landgebruik: extensivering kan lonend zijn. Plant Research International.

Krom, M.P.M.M. de, 2017. Farmer participation in agri-environmental schemes: Regionalisation and the role of bridging social capital. Land Use Policy 60, 352-361.

Lauwere, C. de, \& van der Burg, S. (2019). Verkennende studie naar prikkels voor gedragsverandering naar duurzaam bodemkoolstofbeheer: een literatuurstudie en acht interviews met akkerbouwers en melkveehouders (No. 2019-034). Wageningen Economic Research.

Lesschen, J. P., Reijs, J., Vellinga, T., Verhagen, J., Kros, H., de Vries, M., .. \& Daatselaar, C. (2020). Scenariostudie perspectief voor ontwikkelrichtingen Nederlandse landbouw in 2050 (No. 2984). Wageningen Environmental Research.

Lieshout, M. V. (2014). Framing scales and scaling frames. The politics of scale and its implications forthe governance of the Dutch intensive agriculture (Doctoral dissertation, Wageningen: Wageningen University).

Lokhorst, A.M., Staats, H., Van Dijk, J., Van Dijk, E., De Snoo, G., 2011. What's in it for Me? motivational differences between farmers' subsidised and non-subsidised conservation practices. Applied Psychology 60, 337-353.

Louise Bolk Instituut (2016). Biodiversiteit als basis voor het agrarisch bedrijf. (No. 2016-001 lbD).

Melman, T. C., Ozinga, W. A., Schotman, A. G. M., Sierdsema, H., Schrijver, R. A. M., Migchels, G., \& Vogelzang, T. A. (2013). Agrarische bedrijfsvoering en biodiversiteit: kansrijke gebieden, samenhang met bedrijfstypen, perspectieven (No. 2436). Alterra.

Mertens, F. en H. Blommestijn, 2004. Boer in hart en ziel. Zoektocht naar de diepere drijfveren van agrariërs. Wageningen: Stichting Vrienden van het Platteland.

Michie, S., van Stralen, M.M., West, R., 2011. The behaviour change wheel: A new method for characterising and designing behaviour change interventions. Implementation Science 6.

Mills, J., Gaskell, P., Ingram, J., Dwyer, J., Reed, M., Short, C., 2016. Engaging farmers in environmental management through a better understanding of behaviour. Agriculture and Human Values, 1-17.

Ministerie van Landbouw Natuur en Voedselkwaliteit (LNV). (2018). Landbouw, natuur en voedsel: waardevol en verbonden: Nederland als koploper in kringlooplandbouw.

NCB, 2007. Public Health ethical Issues. London, Nuffield Council on Bioethics.

Paul, H. (2021). Stikstofruimte voor de toekomst: lange termijn verkenning stikstofproblematiek, integraliteit en regie. Algemene Bestuursdienst, Ministerie van Binnenlandse zaken en Koninkrijksrelaties.

Ploeg, J.D. van der, Laurent, C., Blondeau, F., Bonnafous, P., 2009. Farm diversity, classification schemes and multifunctionality. Journal of Environmental Management 90, S124-S131.

Polman, N. (Ed.), Dijkshoorn, M. (Ed.), Doorneweert, B., Rijk, P., Vogelzang, T., Reinhard, S., Smit, B., Splinter, G., Heideveld, A., Geerts, R., Grin, J., Korevaar, H., van Setten, B., \& Vrolijk, M. (2019). 
Verdienmodellen natuurinclusieve landbouw. Wageningen Economic Research.

https://edepot.wur.nl/501143

Polman, N., \& Dijkshoorn-Dekker, M. (2018). Verdienmodellen voor Natuurinclusieve Landbouw. Wageningen Economic Research.

Prokopy, L.S., Floress, K., Klotthor-Weinkauf, D., Baumgart-Getz, A., 2008. Determinants of agricultural best management practice adoption: Evidence from the literature. Journal of Soil and Water Conservation 63, 300-311.

Raad voor de Leefomgeving en Infrastructuur (RLI). (2020). De Bodem bereikt?! Digitale uitgave.

Rijksdienst Voor Ondernemend Nederland (RVO). (10 maart 2021). Verkenning Normeren en Beprijzen. Adviesvraag 20-192.

RMO, 2014. De verleiding weerstaan. Grenzen aan beïnvloeding van gedrag door de overheid. Raad voor Maatschappelijke Ontwikkeling, Den Haag, p. 158.

Runhaar, H. A. C., Polman, N. B. P., Dijkshoorn-Dekker, M. W. C., Smit, A. B., \& Jansen, B. (2020). Wat stimuleert een boer om aan agrarisch natuurbeheer te doen?. Vakblad Natuur BosLandschap, (169), 14-17.

Runhaar, H., Melman, D., Boonstra, F., Erisman, J. W., Horlings, L., de Snoo, G. R., Termeer, K., Wassen, M. J., Westerink, J., \& Arts, B. J. M. (2017). Promoting nature conservation by Dutch farmers: a governance perspective. International Journal of Agricultural Sustainability, 15(3), 264-281. https://doi.org/10.1080/14735903.2016.1232015

Runhaar, H., Polman, N., \& Dijkshoorn-Dekker, M. (2018). Self-initiated nature conservation by farmers: an analysis of Dutch farming. International Journal of Agricultural Sustainability, 16(6), 486-497.

Runhaar, H., Wojtynia, N., Vermunt, D., Hekkert, M., van Dijk, J. Verburg, R., Verweij, P., Wassen, M. (30 april 2020). Hoe maken wij de weg vrij voor natuur-inclusieve melkveehouderij?

Copernicus Instituut voor Duurzame Ontwikkeling, Universiteit Utrecht.

Sanders, M. E., Nieuwenhuizen, W., Dirkx, G. H. P., Schrijver, R. A. M., \& Smidt, R. A. (2013). Bedrijfsvoering zit in de weg: Landbouw slechts beperkt inzetbaar voor natuur- en landschapsbehoud. Landschap: tijdschrift voor landschapsecologie en milieukunde, 30(2), 57-66. https://edepot.wur.nl/272909

Schippers, W., Bax, I. H. W., en Gardenier, M. (2012). Ontwikkelen van kruidenrijk grasland: veldgids. Bureau Groenschrift/ Aardewerk Advies.

Schoonhoven, Y., \& Runhaar, H. (2018). Conditions for the adoption of agro-ecological farming practices: a holistic framework illustrated with the case of almond farming in Andalusia. International Journal of Agricultural Sustainability, 16(6), 442-454.

Schrijver, R. A. M., Rudrum, D. P., \& De Koeijer, T. J. (2008). Economische inpasbaarheid van natuurbeheer bij graasdierbedrijven (No. 80). Wettelijke Onderzoekstaken Natuur \& Milieu.

Schrijver, R., \& Vijn, M. (2018). Naar een Heideboerderij en een nieuwe marke voor de Sallandse Heuvelrug (No. 345). Wageningen University \& Research, Wetenschapswinkel.

Schrijver, R., Bruil, W., Gies, E., Langers, F., Nieuwenhuizen, W. (2019). Verkenning duurzaam grondbeleid Overijsel: opweg naar duurzame pacht. Wageningen Environmental Research. Rapport 2960, ISSN 1566-7197.

Schrijver, R.A.M., Westerink, J., De Jong, K., Smit, A.B., Van der Meer, A.W. en Dijkshoorn-Dekker, M.W.C. (2021). Principes van verdienmodellen voor extensieve landbouwbedrijven. Wageningen Environmental Research, in prep.

Schroeder, L.A., Chaplin, S., Isselstein, J., 2015. What influences farmers 'acceptance of agrienvironment schemes? An ex-post application of the Theory of Planned Behaviour'. Landbauforschung Volkenrode 65, 15-28.

Siebert, R., Toogood, M., Knierim, A., 2006. Factors affecting european farmers' participation in biodiversity policies. Sociologia Ruralis 46, 318-340.

Sijtsema, S.J, Goddijn, S.T, Wolf, C.W.G, Aarts, M.N.C, Tacken, G.M.L, and Verstegen, J.A.A.M. 2009. Groot, Groter, ...Duurzaamst!? Percepties Van Burgers Ten Aanzien Van Schaalgrootte En Schaalvergroting in De Agrarische Sector. LEI. http://edepot.wur.nl/5917

Silvis, H. J., \& Voskuilen, M. J. (2019). Akkerbouwbedrijven: schaalvergroting en intensivering. Wageningen Economic Research.

Silvis, H. J., \& Voskuilen, M. J. (2020). Melkveebedrijven: steeds groter en intensiever. Wageningen Economic Research. 
Silvis, H.J., Schrijver, R., Jellema, A. (2021). Handelingsperspectief door beloningen voor biodiversiteit te stapelen. Wageningen Economic Research.

Sleen, M. van der \& van Benthem, M. (2020). Verduurzaming veehouderij betaald zich maatschappelijk uit. ESB, 105(4791S).

Smits, M. J. W., \& Bos, E. J. (2016). Het stimuleren van ondernemen met natuur: handelingsopties voor de overheid (No. 83). Wettelijke Onderzoekstaken Natuur \& Milieu.

Stichting Grondbeheer: https://www.bdgrondbeheer.nl/

Stichting weidegang: https://www.stichtingweidegang.nl/

Sutherland, L.A., Burton, R.J., 2011. Good farmers, good neighbours? The role of cultural capital in social capital development in a Scottish farming community. Sociologia Ruralis 51, 238-255.

Taskforce Verdienvermogen Kringlooplandbouw. (7 oktober 2019). Goed boeren kunnen boeren niet alleen. Ministerie van Landbouw, Natuur en Voedselkwaliteit.

Termeer, C. J. A. M. (2019). Het bewerkstelligen van een transitie naar kringlooplandbouw. Wageningen University \& Research.

Transitie Coalitie Voedsel. (31 maart 2021). Bodem centraal: zeven aanbevelingen voor de slag om ruimte en stikstof. Geraadpleegd op: https://www.samenvoorbiodiversiteit.nl/updates/bodemcentraal-7-aanbevelingen/351

van Brugge, C. (20 december 2020). Maak een groene grondbank voor verdienmodel boer. Geraadpleegd op: https://www.samenvoorbiodiversiteit.nl/updates/bodem-centraal-7aanbevelingen/351

van Doorn, A., Reijs, J., Erisman, J. W., Verhoeven, F., Verstand, D., de Jong, W., ... \& de Wolf, P. (2021). Integraal sturen op doelen voor duurzame landbouw via KPI's (No. 2021-3092). Wageningen Environmental Research.

Van Gogh Nationaal Park: https://www.vangoghnationalpark.com/biodiversiteitsmonitor

Vink, Martijn \& Boezeman, Daan. 2018. Naar Een Wenkend Perspectief Voor De Nederlandse Landbouw: Voorwaarden Voor Verandering. Den Haag: PBL Planbureau voor de Leefomgeving. http://edepot.wur.nl/455535.

Vink, Martijn, Arjen van Hinsberg, Chris Backes, Daan Boezeman, Petra van Egmond, and Dirk-Jan van der Hoek (2021). Naar Een Uitweg Uit De Stikstofcrisis: Overwegingen Bij Een Integrale, Effectieve En Juridisch Houdbare Aanpak. Den Haag: PBL, Planbureau voor de Leefomgeving.

Visser, A. J., Migchels, G., \& de Jong, D. (2015). Publicatieoverzicht PPS Multifunctionele landbouw 2013-2015. PPO AGV.

Vrolijk, H. C. J., Blokland, P. W., Helming, J. F. M., Luesink, H. H., \& Prins, H. (2010). Economische gevolgen van een beperking van de veestapel: quick scan naar winnaars en verliezers. LEI Wageningen UR.

Vrolijk, H., Reijs, J., \& Dijkshoorn-Dekker, M. (2020). Towards sustainable and circular farming in the Netherlands: Lessons from the socio-economic perspective. Wageningen Economic Research.

Wauters, E., D'Haene, K., Lauwers, L., 2017. The social psychology of biodiversity conservation in agriculture. Journal of Environmental Planning and Management 60, 1464-1484.

Westerink - Petersen, J., Breman, B. C., Smits, M. J., van Alebeek, F. A. N., Migchels, G., Bakker, G., van Amersfoort, M. C., \& Schrijver, R. A. M., 2009. Maatschappelijke prestaties: meer publieke diensten en minder publieke lasten door de landbouw met behulp van het Gemeenschappelijk Landbouwbeleid. (Alterra-rapport; No. 1961). Alterra. https://edepot.wur.nl/133642

Westerink - Petersen, J., Stortelder, A. H. F., Ottburg, F. G. W. A., de Boer, T. A., Schrijver, R. A. M., de Vries, C. K., Plomp, M., Smolders, E. A. A., Eysink, A. T. W., \& Bulten, G. H. (2013). Boeren voor Natuur: hoe werkt het en wat levert het op? (Alterra-rapport; No. 2472). Alterra, Wageningen-UR. https://edepot.wur.nl/281597

Westerink, J., Elings, M., De Kloe-Bouwman, N., \& Slikboer, N. (2019a). Zin in landbouw en zorg: diepere drijfveren van zorgboeren en hoe die tot uiting komen in hun praktijken. (Publicatie / Wageningen University \& Research, Wetenschapswinkel; No. 354). Wageningen University \& Research, Wetenschapswinkel. https://doi.org/10.18174/503205

Westerink, J., de Boer, T. A., Pleijte, M., \& Schrijver, R. A. M. (2019b). Kan een goede boer natuurinclusief zijn? De rol van culturele normen in een beweging richting natuurinclusieve landbouw. (WOt-technical report; No. 161). Wettelijke Onderzoekstaken Natuur \& Milieu. https://doi.org/10.18174/508108 
Westerink, J., Melman, D., Schrijver, R., Schotman, A., \& Visser, T. (2019c). Natuurinclusief voor een goede toekomst: wat valt te leren van Hoeve Stein als voorbeeld van zelfrealisatie van natuur? (Wageningen Environmental Research rapport; No. 2948). Wageningen Environmental Research. https://doi.org/10.18174/476604

Westerink, J., Pérez-Soba, M., van Doorn, A., (2020a). Social learning and land lease to stimulate the delivery of ecosystem services in intensive arable farming. Ecosystem Services 44, 101149.

Westerink, J., Termeer, C., \& Manhoudt, A. (2020b). Identity Conflict? Agri-Environmental Collectives as Self-Governing Groups of Farmers or as Boundary Organisations. International Journal of the Commons, 14(1).

Westerink, J., Plomp, M., Ottburg, F., Zanen, M., \& Schrijver, R. (2018a). Boeren voor Natuur: de ultieme natuurinclusieve landbouw? Lessen van vier pilotbedrijven en relevantie voor beleid. (Wageningen Environmental Research rapport; No. 2858). Wageningen Environmental Research. https://doi.org/10.18174/434934

Westerink, J., Smit, B., Dijkshoorn, M., Polman, N., \& Vogelzang, T., 2018b. Boeren in Beweging: Hoe boeren afwegingen maken over natuurinclusieve landbouw en hoe anderen hen kunnen helpen. Wageningen University \& Research. https://doi.org/10.18174/454040

Wielen, P. van der, Dekking, A. J. G., \& de Jong, D. (2014). Knelpunten in wet- en regelgeving voor de multifunctionele landbouw.

Wilson, G.A., Hart, K., 2000. Financial imperative or conservation concern? EU farmers' motivations for participation in voluntary agri-environmental schemes. Environment and Planning A 32, 2161-2185.

Wit, J. de, \& van Veluw, K. (2017). Verkenning naar een grondgebonden melkveehouderij: minder koeien om binnen milieugrenzen te komen (No. nummer: 2017-015 VG). Louis Bolk Instituut.

Zessen, T. van (2 juni 2018). Extensiveren is een lucratieve strategie. Verschenen in de digitale uitgave van Veeteelt. 
Wageningen Environmental Research Postbus 47

6700 AA Wageningen

T 0317480700

www.wur.nl/environmental-research

Wageningen Environmental Research

Rapport 3110

ISSN 1566-7197
De missie van Wageningen University \& Research is 'To explore the potential of nature to improve the quality of life'. Binnen Wageningen University \& Research bundelen Wageningen University en gespecialiseerde onderzoeksinstituten van Stichting Wageningen Research hun krachten om bij te dragen aan de oplossing van belangrijke vragen in het domein van gezonde voeding en leefomgeving. Met ongeveer 30 vestigingen, 6.800 medewerkers ( $6.000 \mathrm{fte}$ ) en 12.900 studenten behoort Wageningen University \& Research wereldwijd tot de aansprekende kennisinstellingen binnen haar domein. De integrale benadering van de vraagstukken en de samenwerking tussen verschillende disciplines vormen het hart van de unieke Wageningen aanpak. 


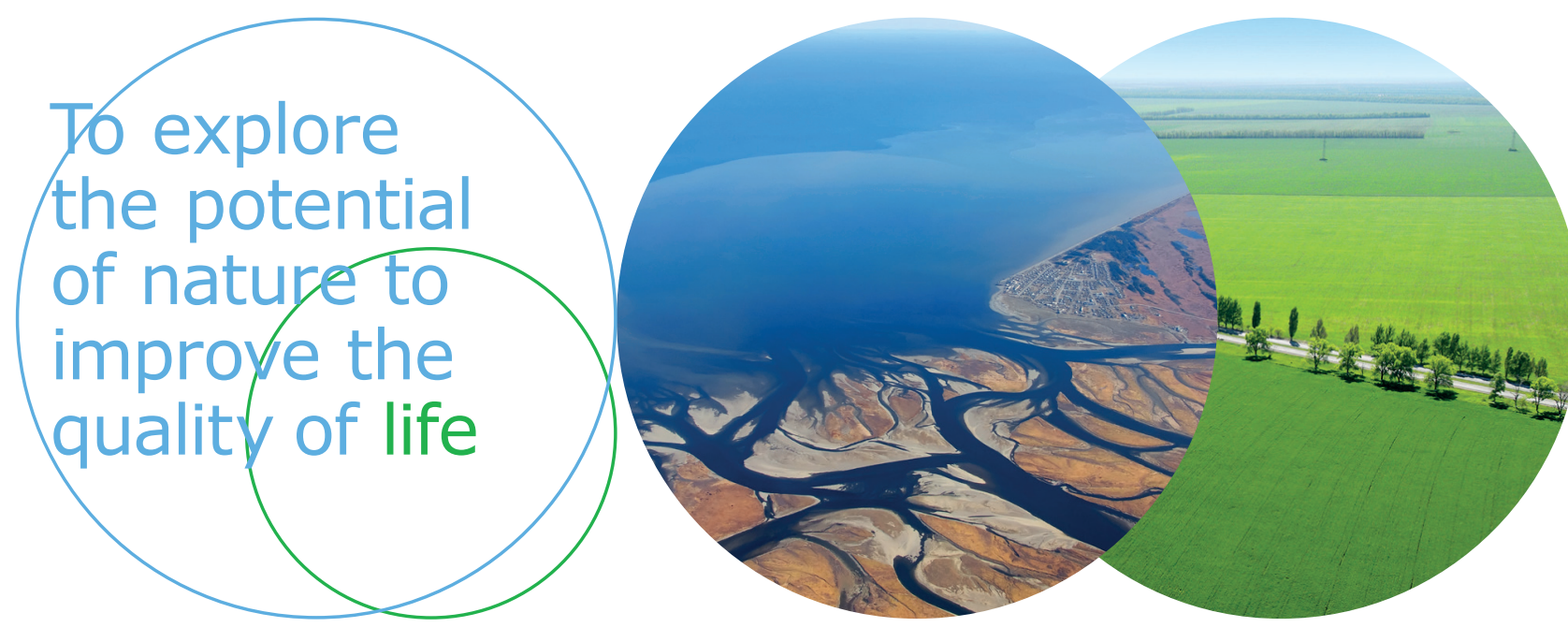

Wageningen Environmental Research Postbus 47

$6700 \mathrm{AB}$ Wageningen

T 317480700

www.wur.nl/environmental-research

Rapport 3110

ISSN 1566-7197
De missie van Wageningen University \& Research is 'To explore the potential of nature to improve the quality of life'. Binnen Wageningen University \& Research bundelen Wageningen University en gespecialiseerde onderzoeksinstituten van Stichting Wageningen Research hun krachten om bij te dragen aan de oplossing van belangrijke vragen in het domein van gezonde voeding en leefomgeving. Met ongeveer 30 vestigingen, 6.800 medewerkers (6.000 fte) en 12.900 studenten behoort Wageningen University \& Research wereldwijd tot de aansprekende kennisinstellingen binnen haar domein. De integrale benadering van de vraagstukken en de samenwerking tussen verschillende disciplines vormen het hart van de unieke Wageningen aanpak. 